\title{
Renal toxicity of proteins
}

Citation for published version (APA):

Zoja, C. (2001). Renal toxicity of proteins. [Doctoral Thesis, Maastricht University]. Universiteit Maastricht. https://doi.org/10.26481/dis.20011212cz

Document status and date:

Published: 01/01/2001

DOI:

$10.26481 /$ dis.20011212cz

Document Version:

Publisher's PDF, also known as Version of record

\section{Please check the document version of this publication:}

- A submitted manuscript is the version of the article upon submission and before peer-review. There can be important differences between the submitted version and the official published version of record.

People interested in the research are advised to contact the author for the final version of the publication, or visit the DOI to the publisher's website.

- The final author version and the galley proof are versions of the publication after peer review.

- The final published version features the final layout of the paper including the volume, issue and page numbers.

Link to publication

\footnotetext{
General rights rights.

- You may freely distribute the URL identifying the publication in the public portal. please follow below link for the End User Agreement:

www.umlib.nl/taverne-license

Take down policy

If you believe that this document breaches copyright please contact us at:

repository@maastrichtuniversity.nl

providing details and we will investigate your claim.
}

Copyright and moral rights for the publications made accessible in the public portal are retained by the authors and/or other copyright owners and it is a condition of accessing publications that users recognise and abide by the legal requirements associated with these

- Users may download and print one copy of any publication from the public portal for the purpose of private study or research.

- You may not further distribute the material or use it for any profit-making activity or commercial gain

If the publication is distributed under the terms of Article $25 \mathrm{fa}$ of the Dutch Copyright Act, indicated by the "Taverne" license above, 


\section{RENAL TOXICITY OF PROTEINS}

Carlamaria Zoja 


\section{RENAL TOXICITY OF PROTEINS}

\section{PROEFSCHRIFT}

ter verkrijging van de graad van doctor aan de Universiteit Maastricht, op gezag van de Rector Magnificus,

Prof. dr. A.C. Nieuwenhuijzen Kruseman, volgens het besluit van het College van Decanen, in het openbaar te verdedigen op woensdag 12 december 2001 om 16.00 uur

door

Carlamaria Zoja

geboren op 9 augustus 1955 te Bergamo, Italie 


\section{Promotor}

Prof. dr. K.M.L. Leunissen

\section{Co-promotor}

Prof. dr. G. Remuzzi (Istituto di Ricerche Farmacologiche Mario Negri, Laboratori Negri Bergamo, Bergamo, Italia)

Beoordelingscommissie

Prof. dr. J.F.M. Smits (voorzitter)

Prof. dr. W. A. Buurman

Prof. dr. J. Floege (RWTH Aachen, Germany)

Prof. dr. H. Koomans (Universiteit Utrecht)

Prof. dr. P.W. de Leeuw 
To: Marco, Francesco, and Edoardo 



\section{CONTENTS}

Chapter 1: Introduction

Chapter 2: Protein overload stimulates RANTES production

by proximal tubular cells depending on NF-kB activation

27

Kidney Int 1998; 53: 1608-1615

Chapter 3: Protein traffic activates NF-kB gene signaling and promotes $\mathrm{MCP}-1$ dependent interstitial inflammation Am J Kidney Dis 2000; 36:1226-1241

Chapter 4: Antiproteinuric therapy while preventing the abnormal protein traffic in proximal tubule abrogates protein- and complement-dependent interstitial inflammation in experimental renal disease J Am Soc Nephrol 1999; 10: 804-813

Chapter 5: Combining an antiproteinuric approach with mycophenolate mofetil fully suppresses progressive nephropathy of experimental animals JAm Soc Nephrol 1999; 10: 1542-1549

Chapter 6: Effect of combining ACE inhibitor and statin in severe experimental nephropathy Kidney Int 2001, submitted

Chapter 7: General Discussion

Curriculum vitae 
, 


\section{CHAPTER 1}

\section{Introduction}

In part published in:

Protein overload activates proximal tubular cells to release vasoactive and inflammatory mediators.

C. Zoja, A. Benigni, G. Remuzzi

Eperimental Nephrology 1999; 7:420-428 


\section{Introduction}

Progression to end-stage renal failure is the final common pathway of many forms of glomerular diseases, independently of the initial insult. Among the several theories on the pathophysiology of progressive nephropathies, the most elegant one has been put forward by Brenner and coworkers [1] who suggested that the initial reduction in nephron number progressively damages the remaining ones, which suffer the consequences of adaptive increases in glomerular pressure and flow. The model of renal mass reduction in the rat helped clarifying the pathological mechanisms of renal adaptation to nephron loss. After severe reduction of renal mass, remnant intact nephrons undergo sudden hypertrophy, with concomitant reduced arteriolar resistance and increased glomerular plasma flow that results from a different decrease in vessel tone that is less in afferent than efferent arterioles. This results in an increase in glomerular hydraulic pressure and more filtrate per nephron. Although such changes compensate for the functional consequences of nephron loss, they are detrimental in the long term. Glomerular capillary hypertension constitutes a noxious stimulus per se to the underlying structures and enlarges the radii of the pores perforating the glomerular membrane by a mechanism partly mediated by angiotensin II. The increase in intraglomerular capillary pressure alters the barrier's size-selective function and causes protein ultrafiltration. Glomerular capillary hypertension and transglomerular protein traffic are both prevented by dietary protein restriction that retards the development of glomerular sclerosis in different rat models of disease progression [2-5]. Even more effective is reducing intraglomerular capillary pressure with angiotensin I converting enzyme (ACE) inhibitors, that consistently protect rats with reduced renal mass [6,7] or experimental diabetes [8,9] from progressive renal injury. As a possible explanation of the fact that hemodynamic changes, specifically glomerular hypertension, lead to progressive renal injury, it has been proposed that high glomerular capillary pressure leads to impaired glomerular permselectivity to proteins, which are then filtered in excessive amounts and accumulate in the lumen of the proximal tubules [10]. The secondary process of tubular epithelial endocytosis of filtered proteins may contribute substantially to promote an interstitial inflammatory reaction that consistently evolves to renal scarring [10].

\section{Protein traffic as fosterer of interstitial inflammation. In vivo studies}

The glomerulus normally limits transcapillary traffic of albumin and other proteins in a manner such that only macromolecules of low molecular weight reach the urinary space and are eventually reabsorbed by proximal tubular cells. An- 
ionic molecules are more restricted than cationic of the same radius, since the renal capillaries also function as a charge-selective barrier. Theoretical models have been developed that assume the glomerular membrane as being perforated by cylindrical pores of continuous log-normal distribution with a small parallel population of large, shunt-like pores [11,12]. Studies in rats with renal vein constriction [13] or passive Heymann nephritis [14] have shown that enhancing intraglomerular capillary pressure enlarges the pore radii, thus altering the barrier size-selective function and causing protein ultrafiltration.

Experimental and human data are available which indicate that in glomerular diseases excessive urinary excretion of albumin and other proteins reflects a permeability dysfunction that shifts size-pore distribution to large nonselective pathways allowing macromolecules to be massively filtered through the capillary $[10,15]$. As a consequence of abnormalities in glomerular barrier function, plasma proteins filtered in excessive amount reach the tubular fluid and are extensively handled by the proximal tubular epithelium. They are endocytosed via clathrin-coated pits by a receptor-mediated or constitutional pathway, and then degraded by lysosomes into the constituent amino acids [16,17]. Proximal tubular cell reserve capacity for this process is limited and increasing the protein load leads to organelle congestion, lysosomal swelling and rupture, eventually exposing cell cytoplasm and renal interstitium to the injurious effect of lysosomal enzymes, which can contribute to promote tubulo-interstitial injury and renal scarring $[18,19]$.

The relationship between proteinuric glomerulopathies and tubulo-interstitial damage has been suggested by many investigators in the early 1970s [see review 20], but despite much speculation, the nature of this interaction was not clarified until several years later. In 1986, it was suggested [21] for the first time that proteins filtered through the glomerular capillary, taken in the past just as a marker of the severity of renal lesions, might have intrinsic renal toxicity, and could play a contributory role in the progression of renal damage. By sequential analysis of renal biopsies from rats with adriamycin nephrosis [21] and from rats with age-related proteinuria [22] it was shown that glomerular lesions correlated with tubulo-interstitial damage which was preceded by protein reabsorption droplets in the cytoplasm of proximal tubular cells with focal breaks along tubular basement membrane and extravasation of the tubular content in the interstitium. Implications of these studies were that protein reabsorption activated proximal tubular cells to promote interstitial infiltration of inflammatory cells in turn responsible for renal fibrosis. The most convincing experimental evidence that proteins leaking into the urinary space serves to trigger tubulo-interstitial inflammation has been provided by models of overload proteinuria. Repeated injections in the rat of albumin artificially increases glomerular barrier permeability and causes massive proteinuria [23]. These events are followed by 
tubular changes with infiltrations of macrophages and $T$ lymphocytes into the renal interstitium [24]. In such models the severity of proteinuria is a major determinant of the degree of interstitial inflammation. Overload proteinuria can also be produced in rats by transplanting a pituitary tumor that causes liver hyperplasia and overproduction of albumin with consequent hyperalbuminuria [25]. In these animals proteinuria is invariably followed by tubulo-interstitial inflammation and finding that $T$ cell depletion while limiting interstitial inflammation had no effect on proteinuria, was taken as an evidence that protein traffic is the inciting event leading to a subsequent inflammatory reaction.

That excess protein reabsorption by proximal tubular cells is instrumental to the development of interstitial inflammation has been convincingly documented by a recent study of our group that provided morphologic evidence in two different models of proteinuric nephropathies that the traffic of abnormally filtered plasma proteins leads to excess protein load in proximal tubules at sites of subsequent tubulo-interstitial inflammation [26]. In rats with 5/6 nephrectomy, albumin and $\operatorname{IgG}$ accumulation by proximal tubular cells was visualized in the early stage, preceding the interstitial infiltration of MHC-II-positive cells and macrophages. The infiltrating cells concentrated almost exclusively in regions containing IgG-positive proximal tubules and tubules with luminal casts. Similar patterns were found in an immune model -passive Heymann nephritis- indicating that the interstitial inflammatory reaction develops at the sites of protein overload, regardless of the type of glomerular injury. In both models an association was found between excess plasma protein reabsorption and the expression of osteopontin, a cytokine relevant to the attraction of mononuclear cells into the renal interstitium. Actually, osteopontin was detectable in cells of proximal tubules congested with IgG and the sites of colocalization revealed strict relationship with adjacent infiltrates [26]. Thus in proximal tubules the augmented filtered protein load may upregulate osteopontin that by virtue of its chemoattractive action promotes macrophage recruitment into adjacent interstitium.

Interstitial inflammatory cells along with tubular epithelial cells are important intrarenal source of growth factors including transforming growth factor $\beta$ (TGF $\beta$ ), that stimulate interstitial fibroblasts. TGF $\beta$ is also the best characterized stimulus that induces transdifferentiation and myofibroblast transformation of tubular epithelial cells [27].

\section{Mechanisms of tubular protein reabsorption}

Under physiological conditions proximal tubular epithelial cells reabsorb proteins very efficiently by a process of endocytosis that removes from the tubular 
fluid more than $90 \%$ of the filtered proteins. Following uptake by endocytosis proteins undergo intracellular trafficking through a number of endocytic vesicular structures culminating in the entry into lysosomes where proteins are broken down to constituent aminoacids and small peptides. Park and Maack [28] using isolated perfused tubule segments from rat kidney identified a dual system of albumin uptake: a low capacity pathway transporting phisiological loads, and a high capacity one dealing with filtered proteins that far exceed the normal concentration in the lumen. Efforts have been made in the recent years to understand the mechanisms of tubular protein reabsorption. Using proximal tubular-derived opossum kidney cell line (OK cells) it has been determined that albumin endocytosis occurs via a receptor-mediated mechanism from the apical surface of these cells and that a heterotrimeric $G$ protein is implied in endocytic regulation [29]. Other studies described that albumin endocytosis in OK cells is dependent on actin and microtubules in that integrity of the actin cytoskeleton is an absolute prerequisite for albumin endocytosis, whereas microtubules facilitate endocytic uptake [30]. Uptake is regulated by protein kinases (PK) A and $\mathrm{C}$ and tyrosine kinases (TRK), with different time course and by different mechanisms [30,31].As for the nature of the receptor responsible for albumin endocytosis, an albumin binding protein (ABP) has been purified from the brush border membrane of rat proximal tubular cells [32]. The ABP is present along the whole length of the proximal tubule, in the apical parts of proximal tubular cells. Other studies showed that the protein responsible for albumin uptake in rat renal proximal tubule is megalin/gp 330 that functions as a receptor for reabsorption of albumin and other proteins [33]. Megalin is a transmembrane glycoprotein belonging to the LDL receptor family. In proximal tubule megalin is localized in the brush border region of the cells in strict association with components of the endocytic apparatus. In addition it is expressed in lung, embryonic yolk sac, placenta and other organs. Consistently with its location and molecular structure, megalin acts as a multifunction receptor for different ligands including PA/PAI-I complexes, lipoprotein lipase, apolipoproteins, polybasic drugs, transcobalamin-vitamin B12, albumin, and the receptor-associated protein (RAP). In megalin knockout mice a lack of functional endocytic apparatus has been described [for review 34]. Cubilin, is a recently cloned 460 $\mathrm{kDa}$ glycoprotein heavily expressed in the brush borders and intracellular endocytic compartments of proximal tubular epithelial cells [35]. Cubilin has been shown to be devoid of transmembrane domain. However, it binds with high affinity to the transmembrane endocytic receptor megalin and it has been proposed that megalin can act as a coreceptor active in endocytosis and intracellular trafficking of cubilin. Ligands for cubilin include intrinsic factor B12, albumin, HDL, ApoA-I, transferrin, IgG light chains, RAP. Cubilin and megalin 
have been proposed to interact at the cell membrane to mediate endocytosis of ligands including vitamin $\mathrm{D}$ binding protein (DBP), albumin and transferrin. Dogs with an inherited defect causing absent surface expression of cubilin, possibly as a consequence of its retention in an intracellular compartment, showed increased urinary excretion of albumin and decreased tubular albumin reabsorption. Megalin-knockout mice also showed decreased tubular albumin uptake and a threefold increase in albumin/creatinine excretion ratio. In addition to a direct megalin-dependent pathway of albumin uptake, an indirect pathway is suggested to involve the binding of albumin to cubilin followed by endocytosis of cubilin-albumin complex mediated by megalin.

As for IgG, it has been recently showed that reabsorption of this protein from tubular fluid may occur via a type of $F_{c}$ receptor $(\mathrm{FcRn})$ which is expressed on the proximal tubular brush border in the normal human kidney [36].

\section{Filtered proteins as a cause of tubular cell dysfunction}

In glomerular proteinuria filtered albumin is partly excreted in the urine but tubular reabsorption rates rise progressively with filtered load. Excessively filtered proteins activate a lysosomal processing pathway that ultimately causes lysosomal swelling and rupture, impairing cell function and exposing renal interstitium to the injurious effect of lysosomal enzymes. Finding that in experimental nephrosis proximal tubular cysteine proteases enhance their activity in response to increased protein delivery can be taken as a proof of the negative impact of protein over-reabsorption on proximal tubular cell function [37].

Another example is the case of transferrin. When transferrin crosses the glomerular barrier in critical amounts the local acidic $\mathrm{pH}$ of proximal tubular fluid favors release of free iron, a known toxin to tubular cells [38]. Proximal tubular cells in culture loaded with holotransferrin ( $\mathrm{Tf}-\mathrm{Fe}$ ) undergo lipid peroxidative damage in the cytosol and cell membrane as evidenced by increased lactic dehydrogenase release and malondialdehyde generation [39]. In vivo part of the reabsorbed iron is extruded by the cell back into the final urine. Hence, in nephrotoxic serum nephritis the extent of tubulo-interstitial injury correlates with iron excretion in the urine [38]. In human proteinuric conditions, such as diabetic nephropathy, iron excretion in the urine is elevated as well, and the activity of lysosomal enzymes in the proximal tubule is enhanced [41].

Tubules express receptors for hormones and growth factors, some of which are filtered as part of non-selective proteinuria in a variety of glomerular diseases. Thus in nephrotic animals and humans, there is an increased urinary excretion of the insulin-like growth factor I (IGF-I), a small peptide with mitogenic activity, that 
in circulating blood is complexed to binding proteins. After filtration IGF-I dissociates from the binding proteins probably because of a reduction in intratubular $\mathrm{pH}$ as a consequence of changes in the composition of tubular fluid. IGF-I stimulates proliferation and the synthesis of collagen type I and IV in proximal tubular cells, effects that are retained by the tubular fluid collected from nephrotic rats and partially prevented by neutralizing IGF-I receptor antibodies [42].

Complement components are also filtered across the glomerular barrier and form deposits along the luminal side of proximal tubular cells in rats with protein overload nephropathy [25], aminonucleoside nephrosis [43] and renal mass ablation [27], a pattern that is commonly observed in kidneys of patients with non-selective proteinuria and correlates with urinary complement excretion. C3 and $\mathrm{C} 5 \mathrm{~b}-9$ can promote tubular injury and interstitial inflammation by generating oxygen free radicals and chemotactic gradients. In cultured human proximal tubular cells the activation of the alternative pathway of complement leads to fixation of the C5b-9 MAC neoantigen on the cell surface with consequent C5b-9-mediated cytotoxicity [44]. Complement activation on the proximal tubular cell surface triggers the generation of proinflammatory cytokines such as IL-6 and TNF, which may contribute to tubulo-interstitial injury [45].

\section{Tubular protein over-reabsorption incites the synthesis of vasoactive and inflammatory mediators}

Evidence is accumulating in the recent years that the phenotypic character of proximal tubular cells changes in response to protein overloading [46]. Thus in vitro, overloading proximal tubular cells with albumin and other proteins may activate the expression and production of vasoactive and inflammatory molecules, with potential toxic effects on the kidney.

\section{Endothelin}

Endothelins are a family of vasoconstrictor peptides, synthesized and released by endothelial cells, that exist in three structurally and pharmacologically distinct isoforms encoded by distinct genes $[47,48]$. Numerous cells in the kidney synthesize endothelins, including the tubules that secrete abundant amount of endothelin (ET)-1 and lesser amounts of ET-3 [49]. Epithelial cells of the deep medulla generate more ET- 1 than proximal cells and, of note, most of of the released ET-1 is found in the interstitium [50]. We documented that exposure of rabbit proximal tubular RC.SV1 cell line to increasing concentrations of albu$\min (0.1$ to $10 \mathrm{mg} / \mathrm{ml})$ for 6 and 24 hours induced a significant dose-dependent increase in the generation of ET-1 [51]. Since delipidated albumin had the same 
effect on tubular ET-1 synthesis, the lipid component of the protein appears unlikely to be involved. The stimulatory effect on tubular ET-1 synthesis and release was not specific to albumin but was shared by IgG and transferrin. In vivo tubular epithelial cells are organized as a continuous polarized cell layer that serves to separate apical and basolateral compartment with different specific activities [52]. When RC.SV1 cells were grown on filters in bicameral systems became organized in a polarized cell monolayer: they had microvilli on the apical membrane and adjacent cells exhibited marked lateral intercellular digitations and well developed tight junctions in the basolateral domain. Apical exposure of polarized tubular cells to high albumin concentration resulted in an increased ET-1 secretion in the basolateral compartment [51]. Should this occur in vivo an excessive amount of ET-1 may accumulate in the interstitial compartment with a number of implications due to the vasoactive and inflammatory properties of the molecule. Preliminary studies have shown that ET-1 binds to specific interstitial fibroblast receptors and that human interstitial fibroblasts challenged with ET-1 in vitro increase their proliferation rate and actively synthesize extracellular matrix proteins [53]. It seems also that there is an amplification loop that amplifies further enhancements of the ET-1 synthetic rate to the extent that fibronectin, collagen IV, and laminin added to culture media of tubular cells stimulate ET-1 production. ET-1 has chemotactic properties on blood monocytes, and by binding to specific receptors on monocytes/macrophages it induces the secretion of proinflammatory cytokines that could theoretically further contribute to the interstitial inflammatory reaction [54]. Another study [55] highlighted an additional pathway of tubular cell modulation of ET-1 synthesis by reabsorbed proteins. Thus high density lipoproteins stimulated ET-1 release by cultured human proximal tubular cells via a novel cyclic AMP and protein kinase $C$ independent pathway. In vivo evidence is available that an excessive formation of ET- 1 in the kidney may favor progression of renal lesions to the extent that pharmacological manipulation of the ET-1 pathway has a major positive impact on disease progression [56,57]. Enhanced renal synthesis of ET-1 has been reported in different experimental models of proteinuric nephropathies. Thus in rats with remnant kidney renal ET-1 gene expression and excretion of the corresponding peptide in the urine increased time-dependently after surgery and correlated with the rate of progression of the renal damage [58]. Similar results were obtained in rats with passive Heymann nephritis, a model resembling human membranous nephropathy [59]. That enhanced renal synthesis of ET favors the development of renal lesions is suggested by studies in transgenic animals. Mice overexpressing human ET-1 promoter form more ET-1 in their kidneys and develop renal lesions despite they do not develop hypertension [60]. Moreover, rats transgenic for human ET-2 gene are normotensive and phenotypically characterized by re- 
nal lesions reminiscent of those of rats with remnant kidney [61]. Evidence for increased renal ET-1 are available also in patients after unilateral nephrectomy [62] and with chronic glomerulonephritis [63].

In a model of chronic proteinuria, PHN, we investigated the localization of excess ET-1 in the kidney in response to protein traffic and evaluated whether ET-1 synthesis were modulated by drugs that restore the selectivity of the glomerular barrier [64]. While in kidneys from control rats there was weak specific staining for ET-1 in glomeruli, proximal and distal tubules, the signal was strong in PHN, mainly localized in the proximal tubules and around inflammatory cells in interstitial areas. PHN rats chronically treated with an ACE inhibitor and an angiotensin II receptor antagonist, a combined therapy that totally prevented proteinuria and preserved renal structural integrity, had ET-1 staining comparable to controls. In rats with remnant kidney we documented that concomitant to the onset of proteinuria cortical tubules appeared activated to express ET-1 mRNA [65]. Tubular ET-1 overexpression was invariably found in the vicinity of interstitial fibrosis, consistent with the possibility that ET-1 contributes, at least in part, to interstitial injury.

\section{Lipids and lipoproteins}

Because albumin carries many fatty acids, it has been proposed that upon tubular endocytosis of albumin, a lipid-dependent pathway also operates to amplify tubulo-interstitial damage. In proteinuric conditions uptake and degradation of the fatty acids bound to albumin by tubular epithelium release fatty acids into the cytosol -as there are no degradative enzymes for fatty acids in lysosomes- where they cause a toxic insult [66]. A chemotactic lipid has been isolated from the urine of rats with overload proteinuria, which attracted monocytes but not neutrophils [67]. When normal, fresh isolated proximal tubules were exposed to albumin in vitro, they released a lipid factor chromatographically indistinguishable from that isolated from proteinuric urine. Proximal tubules did not release this inflammatory lipid when exposed to delipidated albumin, thus indicating that the generation of this factor occurs as a consequence of tubular metabolism of fatty acids bearing albumin [66]. Human proximal tubular cells in culture take up LDL and HDL with subsequent enhancement of growth and intracellular accumulation of neutral lipids. Although undefined, the epithelial metabolism of the lipid component of these lipoproteins appears to modulate tubular epithelial cell phenotype [66].

\section{RANTES and Monocyte chemoattractant protein-1 (MCP-1)}

Among chemoattractants, RANTES and MCP-1 have been recently proposed as possible mediators of tubulo-interstitial lesions that follow endocytosis of filtered proteins. 
RANTES (Regulated upon Activation, Normal T cell Expressed and Secreted) [68] is a chemokine with potent chemotactic activity for macrophages, granulocytes and T lymphocytes [69] which is expressed by a variety of cell types including lymphocytes, fibroblasts, mesangial cells and renal tubular epithelial cells $[70,71]$. Marked induction of RANTES mRNA occurred after stimulation of tubular cells with TNF, IL-1 and LPS. There is evidence that RANTES gene was upregulated in the kidneys of mice with crescentic glomerulonephritis that were markedly proteinuric, and that the administration of a RANTES antagonist partially reduced proteinuria and limited glomerular and interstitial accumulation of $T$ cells and monocyte/macrophages in these animals [72]. The effect of protein overload on RANTES production by proximal tubular cells in culture has been investigated in Chapter 2 of the present thesis.

MCP-1, is another chemokine with potent chemotactic activity toward monocytes/macrophages and T-lymphocytes, which is produced by monocytes and many other cells, including tubular epithelial cells [73]. Wang et al. [74] showed that in rat proximal tubular cells high concentrations of albumin and transferrin induced a rapid upregulation of MCP-1 mRNA (6-fold increase over control) within 4 hours, that was maintained for at least 24 hour protein challenge. Removal of albumin from the media led to a rapid decline in MCP-1 mRNA, indicating that upregulation of the MCP-1 gene requires continued exposure to proteins. Albumin-induced MCP-1 expression was inhibited by lysine, a potent inhibitor of albumin uptake across the luminal membrane of the proximal tubular cell, and by actinomycin $\mathrm{D}$ that limits gene transcription. In vivo experiments showed high MCP-1 mRNA expression and MCP-1 immunostaining localized to proximal tubules in kidneys of rats with protein overload proteinuria in a phase of the disease characterized by mononuclear cell infiltration [75].

\section{Objectives of the thesis}

In this thesis further investigations were performed to address the renal toxicity of enhanced glomerular protein traffic, with the aims of clarifying the relevant tubular-dependent pathways of interstitial inflammation ultimately responsible for renal scarring and loss of function, and of identifying antiproteinuric and renoprotective therapies to slow or even halt the disease progression to endstage renal failure.

First, in vitro studies were designed to assess whether protein overload could activate cultured proximal tubular epithelial cells to release RANTES, a chemokine with potent chemotactic activity for macrophages, granulocytes and 
T lymphocytes. Given that monocytes and T-lymphocytes are the major cellular component of interstitial inflammatory reaction that follows protein overreabsorption in proteinuric nephropathies, we investigated whether the secretion of RANTES by proximal tubular cells in response to proteins were polarized toward the aspects of cells in intimate contact with the interstitium. Since RANTES, as other chemokine and proinflammatory mediator genes are transcriptionally regulated by NF-kB, we studied whether protein overload directly activated NF-kB and whether NF-kB were involved in protein overload-induced RANTES synthesis (Chapter 2).

From the in vitro setting of proximal tubular cells overloaded with proteins, to provide confirmation that in vivo glomerular protein traffic does modulate NF-kB and NF-kB-dependent inflammatory genes -instrumental to interstitial inflammation- we moved to animal models of progressive proteinuric nephropathies, namely $5 / 6$ nephrectomy and passive Heymann nephritis (PHN) in the rat. In these models we assessed along with proteinuria, renal NF-kB DNA binding activity and gene expression of MCP-1, a NF-kB-dependent gene whose product has potent chemoattractant activity for monocytes/macrophages and lymphocytes. Moreover, we evaluated the effect of reducing protein traffic -by means of an antiproteinuric therapy with $\mathrm{ACE}$ inhibitor- on NF-kB activation, MCP-1 expression, and the extent of accumulation of mononuclear cells into the renal interstitium (Chapter 3).

In kidneys of rats with $5 / 6$ renal mass ablation, filtered albumin and IgG accumulated in proximal tubular cells early after surgery, preceding interstitial infiltration of MHC-II positive cells and macrophages into adjacent interstitium [26]. Among proteins trafficked to the proximal tubule, the third component of complement (C3) can be activated locally and contribute to inflammation at sites of protein reabsorption. We performed an immunohistochemical analysis of the remnant kidneys to assess whether $\mathrm{C} 3$ can be detected in proximal tubular cells in regions of ultrafiltered protein ( $\mathrm{Ig}$ ) accumulation, and to compare the localization of $\mathrm{C} 3$ and $\operatorname{IgG}$ in proximal tubules with those of monocytes/macrophages and other infiltrating cells bearing MHC-II expression into the interstitium. Then, we wanted to establish whether treatment with the antiproteinuric drug lisinopril limited the accumulation of IgG and C3 in proximal tubules and the early interstitial inflammation in this model (Chapter 4).

The production of lymphocyte chemoattractants by tubular epithelium and the consequent lymphocyte infiltration are potential steps of cell-mediated immune reactions leading to chronic tubulointerstitial injury and eventual tubular loss 
and fibrosis. Infiltrating macrophages and presumably dendritic cells at tubular sites of protein overreabsorption strongly expressed surface MHC class II molecule in rats with PHN and importantly, in the remnant kidney model, in which a primary immune mechanism can be excluded. Renal MHC-II expression became increasingly higher as proteinuria and inflammation worsened [26]. Based on these observations, we hypothesized that in proteinuric diseases only partially responsive to $A C E$ inhibitor, protein-dependent stimuli persist and may trigger MHC-II overexpression and T-lymphocyte dependent interstitial reactions. Therefore, we tested the possibility that immune mechanisms have a role in the proteinuric nephropathy of rats with renal mass reduction, in which the progressive renal disease is caused by a non immune insult to the kidney, and we characterized the mononuclear cell populations infiltrating the interstitium in these animals. Then, we evaluated whether lymphocyte dependent interstitial inflammation, while not fully controlled by antiproteinuric therapy (ACE inhibitor) could be further inhibited by concomitant immunosuppression with the antilymphocyte agent mycophenolate mofetil (Chapter 5).

Interstitial inflammation and progression of proteinuric nephropathies can be effectively limited by ACE inhibitors that limit proteinuria and filtered proteindependent signaling for mononuclear cell infiltration and extracellular matrix deposition, effects which along with blocking of angiotensin II (AII) mediated mechanisms of injury, can be attributed to the drug's ability to limit excess protein traffic across the altered glomerular barrier and its deleterious consequences. This was almost invariably achieved when therapy started early after glomerular insult. However, a delayed administration of ACE inhibitor may not be effective enough either in animal models, or, more importantly, in patients possibly referred late in the course of their disease. The identification of multiple cellular mechanisms of injury has led to the concept of simultaneously interrupting disparate events to slow progression of proteinuric glomerulopathies [76]. Given the available evidence that statins, independently of their cholesterol-lowering effect, may also influence pathways involved in inflammatory and fibrogenic processes [77], we assessed the effect of combining lisinopril with simvastatin in a severe model of accelerated passive Heymann nephritis (PHN) in the rat, which may mimic advanced phases of human membranous nephropathy. Treatment was started when the animals had already massive proteinuria and renal lesions. Outcome parameters included blood pressure control, the magnitude of proteinuria, the degree of renal function and glomerular and tubulo-interstitial changes (Chapter 6). 


\section{References}

1. Brenner BM, Meyer TW, Hostetter TH: Dietary protein intake and the progressive nature of kidney disease: the role of hemodynamically mediated glomerular injury in the pathogenesis of progressive glomerular sclerosis in aging, renal ablation, and intrinsic renal disease. N Engl J Med 1982;307:652-659.

2. Hostetter TH, Olson JL, Rennke HG, Venkatachalam MA, Brenner BM: Hyperfiltration in remnant nephrons: a potentially adverse response to renal ablation. Am J Physiol 1981;241:F85-F93.

3. Olson JL, Hostetter TH, Rennke HG, Brenner BM, Venkatachalam MA: Altered glomerular permselectivity and progressive sclerosis following extreme ablation of renal mass. Kidney Int 1982;22:112-126.

4. Wen S-F, Huang T-P, Moorthy AV: Effect of low-protein diet on experimental diabetic nephropathy in the rat. J Lab Clin Med 1985;106:589-597.

5. Hostetter TH, Meyer TW, Rennke HG, Brenner BM: Chronic effects of dietary protein in the rat with intact and reduced renal mass. Kidney Int 1986;30:509-517.

6. Anderson S, Meyer TW, Rennke HG, Brenner BM: Control of glomerular hypertension limits glomerular injury in rats with reduced renal mass. J Clin Invest 1985;76:612-619.

7. Anderson S, Rennke HG, Brenner BM: Therapeutic advantage of converting enzyme inhibitors in arresting progressive renal disease associated with systemic hypertension in the rat. J Clin Invest 1986;77:1993-2000.

8. Zatz R, Dunn BR, Meyer TW, Anderson S, Rennke HG, Brenner BM: Prevention of diabetic glomerulopathy by pharmacological amelioration of glomerular capillary hypertension. J Clin Invest 1986;77:1925-1930.

9. Anderson S, Rennke HG, Garcia DL, Brenner BM: Short and long term effects of antihypertensive therapy in the diabetic rat. Kidney Int 1989;36:526-536.

10. Remuzzi G, Bertani $T$ : Is glomerulosclerosis a consequence of altered glomerular permeability to macromolecules? Kidney Int 1990;38:384-394.

11. Deen WM, Bridges CR, Brenner BM, Myers BD: Heteroporous model of glomerular size selectivity: application to normal and nephrotic humans. Am J Physiol 1985;249:F374-F389.

12. Remuzzi A, Battaglia C, Rossi L, Zoja C, Remuzzi G: Glomerular size selectivity in nephrotic rats exposed to diets with different protein content. Am J Physiol 1987;253:F318-F327.

13. Yoshioka T, Mitarai T, Kon V, Deen WM, Rennke HG, Ichikawa I: Role for angiotensin II in an overt functional proteinuria. Kidney Int 1986;30:538-545.

14. Yoshioka T, Rennke HG, Salant DJ, Deen WM, Ichikawa I: Role of abnormally high transmural pressure in the permselectivity defect of glomerular capillary wall: a study in early passive Heymann nephritis. Circ Res 1987;61:531-538.

15. Remuzzi G, Ruggenenti P, Benigni A: Understanding the nature of renal disease progression. Kidney Int 1997;51:2-15. 
16. Schwegler JS, Heppelmann B, Mildenberger S, Silbernagl S: Receptor-mediated endocytosis of albumin in cultured opossum kidney cells: A model for proximal tubular protein reabsorption. Pflügers Arch 1991;418:383-392.

17. Wall DA, Maack T: Endocytic uptake, transport, and catabolism of proteins by epithelial cells. Am J Physiol 1985;248:C12-C20.

18. Maack T, Park $\mathrm{CH}$, Camargo MJF: Renal filtration, transport, and metabolism of proteins; in Seldin DW, Giebisch G, (eds): The Kidney: Physiology and Pathophysiology. New York, Raven Press, 1985, pp 1773-1803.

19. Maack $\mathrm{T}$ : Changes in the activity of acid hydrolases during renal reabsorption of lysozyme. J Cell Biol 1967;35:268-273.

20. Eddy AA: Experimental insights into the tubulointerstitial disease accompanying primary glomerular lesions. J Am Soc Nephrol 1994;5:1273-1287.

21. Bertani T, Cutillo F, Zoja C, Broggini M, Remuzzi G: Tubulointerstitial lesions mediate renal damage in adriamycin glomerulopathy. Kidney Int 1986;30:488-496.

22. Bertani T, Zoja C, Abbate M, Rossini M, Remuzzi G: Age-related nephropathy and proteinuria in rats with intact kidneys exposed to diets with different protein contents. Lab Invest 1989;60:196-204.

23. Weening JJ, Van Guldener C, Daha MR, Klar N, Van Der Wal A, Prins FA: The pathophysiology of protein-overload proteinuria. Am J Pathol 1987;129:64-73.

24. Eddy AA, McCulloch L, Adams J, Liu E: Interstitial nephritis induced by proteinoverload proteinuria. Am J Pathol 1989;135:719-733.

25. Mori H, Yamashita H, Nakanishi C, Koizumi K, Makino S, Kishimoto Y, Hayashi Y: Proteinuria induced by transplantable rat pituitary tumor MtT SA5. Model for homologous protein overload proteinuria. Lab Invest 1986;54:636-644.

26. Abbate M, Zoja C, Corna D, Capitanio M, Bertani T, Remuzzi G: In progressive nephropathies, overload of tubular cells with filtered proteins translates glomerular permeability dysfunction into cellular signals of interstitial inflammation. J Am Soc Nephrol 1998;9:1213-1224.

27. Zeisberg M, Strutz F, Muller G: Renal fibrosis: an update. Curr Opin Nephrol Hypert 2001; 10:315-320.

28. Park $\mathrm{CH}$, Maack T: Albumin absorption and catabolism by isolated perfused proximal convoluted tubules of the rabbit. J Clin Invest 1984;73:767.

29. Brunskill NJ, Cockcroft N, Nahorski S, Walls J: Albumin endocytosis is regulated by heterotrimeric GTP-binding protein Gai-3 in opossum kidney cells. Am J Physiol 1996;271:F356-F364.

30. Gekle M, Mildenberger S, Freudinger R, Schwerdt G, Silbernagl S: Albumin endocytosis in OK cells: dependence on actin and microtubules and regulation by protein kinases. Am J Physiol 1997;272:F668-F677.

31. Gekle M, Mildenberger S, Freudinger R, Silbernagl S: Long-term protein exposure reduces albumin binding and uptake in proximal tubule-derived opossum kidney cells. J Am Soc Nephrol 1998;9:960-968. 
32. Cessac-Guillemet AL, Mounier F, Borot $\mathrm{C}$, et al.: Characterization and distribution of albumin binding protein in normal rat kidney. Am J Physiol 1996;271:F101-F107

33. Cui-S, Verroust PJ, Moestrup SK, Christensen EI: Megalin/gp330 mediates uptake of albumin in renal proximal tubule. Am J Physiol 1996;271:F900-F907.

34. Verroust PJ, Kozyraki R: The roles of cubilin and megalin, two multiligand receptors, in proximal tubule function: possible implication in the progression of renal disease. Curr Opin Nephrol Hypert 2001; 10:33-38.

35. Birn H, Fyfe JC, Jacobsen $\mathrm{C}$ et al: Cubilin is an albumin binding protein important for renal tubular albumin reabsorption. J Clin Invest 2000; 105: 1353-1361.

36. Haymann J-P, Levraud J-P, Bouet $S$ et al.: Characterization and localization of the neonatal Fc receptor in adult human kidney. J Am Soc Nephrol 2000;, 11:632-639.

37. Olbricht CJ, Cannon JK, Garg LC, Tisher CC: Activities of cathepsin B and L in isolated nephron segments from proteinuric and non proteinuric rats. Am J Physiol 1986;250:F1055-F1062.

38. Zager RA, Schimpf BA, Bredl CR, Gmur DJ: Inorganic iron effects on in vitro hypoxic proximal tubular cell injury. J Clin Invest 1993;91:702-708.

39. Chen L, Boadle RA, Harris DCH: Toxicity of holotransferrin but not albumin in proximal tubule cells in primary culture. J Am Soc Nephrol 1998;9:77-84.

40. Alfrey AC, Froment DH, Hammond WS: Role of iron in tubulointerstitial injury in nephrotoxic serum nephritis. Kidney Int 1989;36:753-759.

41. Howard RL, Buddington B, Alfrey AC: Urinary albumin excretion, transferrin and iron excretion in diabetic patients. Kidney Int 1991;40:923-926.

42. Hirschberg R: Bioactivity of glomerular ultrafiltrate during heavy proteinuria may contribute to renal tubulo-interstitial lesions. J Clin Invest 1996;97:116-124.

43. Nomura A, Morita Y, Maruyama S, et al.: Role of complement in acute tubulointerstitial injury of rats with aminonucleoside nephrosis. Am J Pathol 1997;151:539-547.

44. Biancone L, David S, Della Pietra V, Montrucchio G, Cambi V, Camussi G: Alternative pathway activation of complement by cultured human proximal tubular epithelial cells. Kidney Int 1994;45:451-460.

45. David S, Biancone L, Caserta C, Bussolati B, Cambi V, Camussi G: Alternative pathway complement activation induces proinflammatory activity in human proximal tubular epithelial cells. Nephrol Dial Transplant 1997;12:51-56.

46. Remuzzi G: Abnormal protein traffic through the glomerular barrier induces proximal tubular cell dysfunction and causes renal injury. Curr Opin Nephrol Hyperten 1995;4:339-342.

47. Remuzzi G, Benigni A: Endothelins in the control of cardiovascular and renal function. Lancet 1993;342:589-593.

48. Yanagisawa M, Kurihara $H$, Kimura $S$, Tomobe $Y$, Kobayashi M, Mitsui $Y$, Yazaki $Y$, Goto K, Masaki T: A novel potent vasoconstrictor peptide produced by vascular endothelial cells. Nature 1988;322:411-415. 
49. Kohan DE: Endothelin synthesis by rabbit renal tubule cells. Am J Physiol 1991;261:F221-F226.

50. Kohan DE, Padilla E: Endothelin-1 is an autocrine factor in rat inner medullary collecting ducts. Am J Physiol 1992;32:F607-F612.

51. Zoja C, Morigi M, Figliuzzi M, Bruzzi I, Oldroyd S, Benigni A, Ronco PM, Remuzzi G: Proximal tubular cell synthesis and secretion of endothelin-1 on challenge with albumin and other proteins. Am J Kidney Dis 1995;26:934-941.

52. Fish EM, Molitoris BA: Alteration in epithelial polarity and the pathogenesis of disease states. New Engl J Med 1994;330:1580-1588.

53. Ong ACM, Jowett TP, Firth JD, Burton S, Kitamura M, Fine LG: A new paracrine loop implicated in human tubulo-interstitial fibrosis: tubular-derived endothelins modulate renal interstitial fibroblast function. J Am Soc Nephrol 1993;4:473 (abstract)

54. Achmad TH, Rao GS: Chemotaxis of human blood monocytes toward endothelin-1 and the influence of calcium channel blockers. Biochem Biophys Res Commun 1992;189:994-1000.

55. Ong AC, Jowett TP, Moorhead JF, Owen JS: Human high density lipoproteins stimulate endothelin-1 release by cultured human renal proximal tubular cells. Kidney Int 1994;46:1315-1321.

56. Benigni A, Zoja C, Corna D, Orisio S, Longaretti L, Bertani T, Remuzzi G: A specific endothelin subtype $A$ receptor antagonist protects against injury in renal disease progression. Kidney Int 1993;44:440-444.

57. Nakamura T, Ebihara I, Tomino Y, Koide H: Effect of a specific endothelin A receptor antagonist on murine lupus nephritis. Kidney Int 1995;47:481-489.

58. Orisio S, Benigni A, Bruzzi I, Corna D, Perico N, Zoja C, Benatti L, Remuzzi G: Renal endothelin gene expression is increased in remnant kidney and correlates with disease progression. Kidney Int 1993;43:354-358.

59. Zoja C, Corna D, Bruzzi I, Foglieni C, Bertani T, Remuzzi G, Benigni A: Passive Heymann Nephritis: Evidence that angiotensin-converting enzyme inhibition reduces proteinuria and retards renal structural injury. Exp Nephrol 1996;4:213-221.

60. Theuring F, Schmager F, Thone-Reinicke CE, et al.: Transgenic mice in endothelin research. Fourth International Conference on Endorhelin, London April 23-26 1995; 146 (abstract)

61. Hocher B, Liefeldt L, Thone-Reineke Cet al: Characterization of the renal phenotype of transgenic rats expressing the human endothelin-2 gene. Hypertension 1996;28:196-201.

62. Takeda M, Komeyama T, Tsutsui T, Mizusawa T, Katayama Y, Go H, Tamaki M, Hatano A: Changes in urinary excretion of endothelin-1 like immunoreactivity before and after unilateral nephrectomy in humans. Comparison with other urinary parameters and unilateral adrenalectomy. Nephron 1994;67:180-184.

63. Ohta K, Hirata Y, Shichiri M, Kanno K, Emori T, Tomita K, Marumo F: Urinary excretion of endothelin-1 in normal subjects and patients with renal disease. Kidney Int 1991;39:307-311. 
64. Zoja C, Liu X-H, Abbate M, Corna D, Schiffrin EL, Remuzzi G, Benigni A: Angiotensin II blockade limits tubular protein overreabsorption and the consequent upregulation of endothelin 1 gene in experimental membranous nephropathy. Exp Nephrol 1998;6:121-131.

65. Bruzzi I, Corna D, Zoja C, Orisio S, Schiffrin EL, Cavallotti D, Remuzzi G, Benigni A: Time course and localization of endothelin-1 gene expression in a model of renal disease progression. Am J Pathol 1997;151:1241-1247.

66. Schreiner GF: Renal toxicity of albumin and other lipoproteins. Curr Opin Nephrol Hyperten 1995;4:369-373.

67. Kees-Folts D, Sadow JL, Schreiner GF: Tubular catabolism of albumin is associated with the release of an inflammatory lipid. Kidney Int 1994;45:1697-1709.

68. Oppenheim JJ, Zachariae CO, Mukaida N, Matsushima K: Properties of the novel proinflammatory supergene "intercrine" cytokine family. Annu Rev Immunol 1991;9:617-648.

69. Schall TJ, Bacon K, Toy KJ, Goeddel DV: Selective attraction of monocytes and T lymphocytes of the memory phenotype by cytokine RANTES. Nature 1990;347:669.

70. Wolf G, Luckow B, Schlondorff D: Molecular biology and function of the chemoattractant cytokines RANTES and CSF-1; in Schlondorff D, Bonventre JV, (eds): Molecular Nephrology. Kidney Function in Health and Disease. New York, Marcel Dekker, Inc., 1995, pp 673-679.

71. Heeger P, Wolf G, Meyers C, Sun MJ, O'Farrell SC, Krensky AM, Neilson EG: Isolation and characterization of $\mathrm{cDNA}$ from renal tubular epithelium encoding murine Rantes. Kidney Int 1992;41:220-225.

72. Lloyd CM, Minto AW, Dorf ME, Proudfoot A, Wells TNC, Salant DJ, GutierrezRamos J-C: RANTES and monocyte chemoattractant protein-1 (MCP-1) play an important role in the inflammatory phase of crescentic nephritis, but only MCP-1 is involved in crescent formation and interstitial fibrosis. J Exp Med 1997;185:1371-1380.

73. Luckow B, Schlöndorff D: The monocyte chemoattractant protein 1; in Schlöndorff D, Bonventre JV, (eds): Molecular Nephrology. Kidney Function in Health and Disease. New York, Marcel Dekker, Inc., 1995, pp 653-671.

74. Wang Y, Chen J, Chen L, Tay Y-C, Rangan GK, Harris DCH: Induction of monocyte chemoattractant protein-1 in proximal tubule cells by urinary protein. J Am Soc Nephrol 1997;8:1537-1545.

75. Eddy AA, Giachelli CM: Renal expression of genes that promote interstitial inflammation and fibrosis in rats with protein-overload proteinuria. Kidney Int 1995;7:1546-1557.

76. Remuzzi G, Bertani T: Pathophysiology of progressive nephropathies. N Engl J Med 1998; 339:1448-1456.

77. Oda H, Keane WF: Recent advances in statins and the kidney. Kidney Int 1999; 56: Suppl 71:S2-S5. 
$$
\text { . }
$$ 


\section{CHAPTER 2}

\section{Protein overload stimulates RANTES production by proximal tubular cells depending on NF-kB activation}

C. Zoja, R. Donadelli, S. Colleoni, M. Figliuzzi,

S. Bonazzola, M. Morigi, G. Remuzzi

Kidney International 1998; 53:1608-1615 


\title{
Protein overload stimulates RANTES production by proximal tubular cells depending on NF- $\kappa \mathrm{B}$ activation
}

\author{
Carla Zoja, Roberta Donadelli, Stella Colleoni, Marina Figluzzi, Samantha Bonazzola, \\ Marina Morigi, and Giuseppe Remuzzi
}

Mario Negri Institute for Phamacological Research, and Division of Nephrology and Dialysis, Azienda Ospedaliera, Ospedali Riuniti di Bengamo, Bergamo, lialy

\begin{abstract}
Protein overload stimulates RANTES production by proximal tubular cells depending on NF-rEB activation. Abnormal traffic of proteins through the glomerular capillaty has an intrinsic renal toxicity possibly linked to the subsequent process of proximal tubular reabsorption. Here we investigated in vitro the effect of protein overload on proximal tubular cel production of RANTES, a nuclear factor- $\kappa \mathrm{B}$ (NF- $\mathrm{NB}$ )-dependent chemokine with potent chemotactic activity for monocytes/macrophages and $T$ lymphocytes. Contluent pig LLC-PK, cells were incubated for 24 and 48 hours with Eagle's MEM plus $0.5 \%$ FCS containing bovine serum albumin (BSA, 1 to $30 \mathrm{mg} / \mathrm{ml}$ ). Tumor necrosis factor- $\alpha$ (TNF- $\alpha, 100 \mathrm{U} / \mathrm{ml}$ ) was used as a positive control. RANTES was measured in cell supernatants by ELISA. Bovine serum albumin (BSA) induced a time- and dose-dependent increase in proximal tubular cell RANTES production. Selected experiments using transwells showed that the RANTES rclcase was predominantly basulateral. The stimulatory effect on tubular RANTES was not specific to albumin but was shared by immunoglobulin (Ig) G. We then explored the role of NF- $k B$ on BSA-induced RANTES. The NF- $\mathrm{kB}$ inhibiturs pyrrolidine dithiocarbamate (PDTC; $25 \mu \mathrm{M}$ ) and sodium salicylate (10 mM) significantly reduced BSA-induced RANTES production. Electrophoretic mobility shift assay of nuclcar extracts of LLC-PK exposed to BSA revealed an intense NF- $\kappa$ B activation as early as 30 minutes in a dose-dependent fashion, which was inhibited by PDTC Supershift analysis revealed that the protein subunits of activated NF- $\times B$ were $\mathrm{p} 65 / \mathrm{p} 65$ homodimer, $\mathrm{p} 65 / \mathrm{cRel}, \mathrm{p} 50 / \mathrm{cRel}$ and $\mathrm{p} 50 / \mathrm{p} 65$ heterodimers. Given its chemotactic activity, RANTES released into the interstitium might promote inflammatory cell recruilment and contribute to interstitial inflammation and renal diseasc progression.
\end{abstract}

Chronic renal diseases with highly enhanced glomerular permeability to proteins are accompanied by tubulointerstitial inflammation and scarring and time progression to renal function deterioration $[1,2]$. In the recent years several studies have indicated that proteins filtered through the glomerular capillary in cxcessive amount have an intrinsic renal toxicity at least partially linked to their accumulation into proximul tubular cell cytoplasm during the process of reabsorption along the nephron [3]. Thus, in experimental models of overluad proteinuria, repeated i.v. injections of albumin artificially increase glomerular barrier pcrme-

Key words: renal toxicity, chemokines, progressive renal discase, interstial inflammation, proteinuria.

Received for publication October 8,1997

and in revised form December 30, 1997

Accepted for publication January 2, 1998

(C) 1998 by the International Society of Nephrology ability and cause massive proteinuria [4, 5]. These events are followed by tubular changes with infiltrations of macrophages and $T$ lymphocytes into the renal interstitium [6]. In such models the severity of proteinuria is a major determinant of the degree of interstitial inflammation [6]. In rats with overload proleinuria produced by transplanting a pituitary tumor, findings of $T$ cell depletion while limiting interstitial inflammation had no effect on urinary protein excretion [7], were taken as an evidence that protein traffic is the inciting event lcading to a subsequent inflammatory reaction. Eventually interstitial inflammation triggers interstitial fibroblast proliferation and accumulation of extracellular matrix proteins [8-10], which contributc to scarring lesions and renal disease progression. Studies have been devoted to clarifying the biochemical pathways spccifically activated by excessive tubular reabsorption, and evidence is now available that the phenotypic character of proximal tubular epithelial cells changes in response to protein ovcrloading. Thus, in vitro, overloading proximal tubuli with albumin and other proteins activates the transcription of a number of genes encoding vasoactive and inflammatory molccules [11-14], with potentially toxic effects on the kidncy. For instance, studies have found that overloading proximal tubular cells in culture with albumin stimulated the synthesis and release of endothelin-1 (ET-1), an effect independent of the lipid component of the molecule and not confined to albumin but also observed with other proteins like IgG and transferrin [11]. ET-1 secrction by protein-overloaded tubular cells is polarized towards the basolateral compartment [11], and can therefore exert a pivotal rolc in interstitial inflammation and fibrosis. Actually, ET-1 is chemotactic for macrophages [15] and stimulates both interstitial fibroblast proliferation and extracellular matrix synthesis [16].

Among other chemoattractants, monocyte chemoattractant protein-1 (MCP-1), a chemokine with potent chemotactic activity toward monocytes/macrophages and T-lymphocytes $[17,18]$, has been proposed as one possible mediator of tubulointerstitial lesions that follow endocytosis of fittered proteins. Thus, MCP-1 mRNA was induced in proximal tubular cells challenged in vitro with proteins at concentrations comparable to those found in proteinuric urine [14]. Up-regulation of the MCP-1 gene depends on the activity of the transcription factor nuclear factor kappa $B$ (NF- $\mathrm{B}$ ) $[19,20]$, which is present in the inactive form in the cytoplasm of most cells and is activated upon proteolytic degradation of the inhibiting subunit $I \kappa B$ [21-23]. Congestion of cell 
endoplasmic reticulum with viral proteins triggers NF- $\kappa B$ activation through a mechanism-probably involving the production of oxygen radicals [24]-which induces the transcription of interferon and cytokine genes, representing a fast and effective cell antiviral response. That excess proteins in the proximal tubular epithelium serve to up-regulate an NF- $\kappa$ B target gene like MCP-1 would possibly indicate a more general mechanism of cell activation in response to protein stress [24], which may wcll involve other gene products. Among NF- $\kappa \mathrm{B}$ dependent gencs, the chemokine RANTES (regulated upon activation, normal $T$ cell expressed and secreted) [25], which has potent chemotactic activity for macrophages, granulocytes and $T$ lymphocytes [26], appears of particular interest in this context. RANTES is expressed by a variety of cell types including lymphocytes, fibroblasts, mesangial cells and renal tubular epithelial cells [27-29]. Marked induction of RANTES genc occurs after stimulation of mesangial and tubular cells with tumor necrosis factor (TNF), interleukin (IL)-1, lipopolysaccharide (LPS) or aggregated IgG [28-30], and experimental evidence suggests a functional role for RANTES in the inflammatory phase of crescentic nephritis [31] and in the Thy-1.1 model of mesangioproliferative glomerulonephritis [32]. Molecular studies have identified NF- $\kappa \mathrm{B}$ binding sitcs within the promoter region of RANTES gene [33].

In the present study we sought to: $(I)$ evaluate the effect of protein overload on RANTES production by proximal tubular cells in culture; (2) cstablish whether protein overload directly activated the transcriptional factor NF- $\mathrm{B}$; (3) determine whether NF- $\mathrm{B}$ were involved in protein overload-induced RANTES synthesis.

\section{METHODS}

\section{Cell culture}

LLC-PK, cclls are a permanent, well-characterized proximal tubular cell line from the pig [34], and were obtained from the American Type Culture Collection (Rockville, MD, USA). They were grown in Eagle's minimum essential medium in Earle's BSS (Gibco, Grand Island, NY, USA) supplemented with $10 \%$ fetal calf scrum (FCS; Gibco), $2 \mathrm{~mm}$ glutamine and nonessential amino acids (Gibco) in $5 \% \mathrm{CO}_{2}-95 \%$ air at $37^{\circ} \mathrm{C}$. The cells were subcultured using $0.25 \%$ trypsin-0.02\% EDTA (Gibco).

\section{Cell incubation}

LLC-PK ${ }_{1}$ cells were used between the $205^{\text {th }}$ and $230^{\text {th }}$ passages. To study the RANTES production cells were seeded in six-well tissue culture plates (Falcon Labware Division, Becton Dickinson, Milan, Italy). When conflucncy was reached the cells were stimulated with bovine scrum albumin (BSA; 1, 10,30 mg/ml; Sigma Chemical, St. Louis, MO, USA) or TNF- $\alpha(100 \mathrm{U} / \mathrm{ml}$; BASF KNOLL, Ludwigshafen, Germany), or were incubated with control medium (Eagle's plus $0.5 \%$ FCS) for 24 or 48 hours. In additional experiments the cells were incubated with fatty acid free-BSA $(10 \mathrm{mg} / \mathrm{ml}$; Sigma) or with bovinc immunoglobulin $G$ (IgG, $10 \mathrm{mg} / \mathrm{ml}$; Sigma) for 48 hours. BSA and fatty-acid free BSA used in these studies contained $<0.1 \mathrm{ng} / \mathrm{mg}$ LPS. Supcrnatants were harvested and assessed for RANTES production; cells in each well were trypsinized and counted to express the amount of RANTES as $p g / 10^{6}$ cells.

We chose a range of protein concentrations comparable to that used in other studies $[11,14]$. Such conccntrations are higher than those medsured by micropuncture studies in the proximal tubular fluid of rats with experimental nephrosis [35], but in vivo tubular changes manifest only after a prolonged exposure of proximal tubuli to filtered proteins.

To cxamine whether tubular secretion of RANTES were polarized, LLC-PK, cells were grown on Transwell chambers $(0.4$ $\mu \mathrm{m}$ pore size, $24.5 \mathrm{~mm}$ diameter; Costar Data Packaging, Cambridge, MA, USA) and maintained at confluence for four days hefore use. The upper chamber, which corresponded to the apical side of the tubular cells, contained $1.5 \mathrm{ml}$ of medium alone or medium in the presence of BSA $(10 \mathrm{mg} / \mathrm{ml})$, and the lower one, corresponding to the basolateral side, contained $2.6 \mathrm{ml}$ of medium alone. After a 48 hour incubation, supcrnatants in the upper chamber and in the lower one were harvested and assessed for RANTES.

To study a possible relationship between protein overloadinduced RANTES production and the transcriptional factor NF$\kappa B, L L C-P K_{1}$ cells were plated on six-well tissue culture plates and when confluent were treated with the NF- $K B$ inhibitors pyrrolidinc dithiocarbamatc (PDTC; 10, $25 \mu \mathrm{M}$; Sigma) [19] and sodium salicylate $(5,10 \mathrm{~mm}$; Sigma) [36] for one hour prior and during 48 hour incubation with BSA $(10 \mathrm{mg} / \mathrm{ml})$. At the end of incubation RANTES was measured in supernatants.

To investigate whether protein overload activated tubular NF$\kappa \mathrm{B}, \mathrm{LLC} \mathrm{PK}_{1}$ cells were seeded in $100 \mathrm{~mm}$ plastic dishes (Falcon) and when confiuent were exposed to BSA $(10,30 \mathrm{mg} / \mathrm{ml})$ in thc absence or presence of PDTC ( $25 \mu \mathrm{M}, 1$ hr pre-treatment), TNF- $\alpha$ $(100 \mathrm{U} / \mathrm{ml})$, or control medium for 30 minutes. Nuclear proteins were extracted for clectrophorctic mobility shift analysis (EMSA).

\section{RANTES measurement by enzyme linked-immunosorbent assay (ELISA)}

RANTES production in tubular cell supernatants was quantified by ELISA using a commercially available kit (Biotrak ${ }^{70}$; Amersham Life Science, Little Chalfont, Buckinghamshire, UK). The lowest detectable concentration of RANTES measured by this kit was $2.5 \mathrm{pg} / \mathrm{ml}$. No significant cross-reactivity or interference with other cytokines was reported. The recovery of RANTES for cell culture supernatants averages $97 \%$.

\section{Preparation of nuclear extracts}

Nuclear extracts were prepared according to Satriano and Schlondorff [37] with minor modifications. After washing with phosphate buffered saline, cells were harvested and resuspended in $2 \mathrm{ml}$ of hypotonic buffer A (10 mM Hepes pH 7.6, $15 \mathrm{mM} \mathrm{KCl}$ $2 \mathrm{mM} \mathrm{MgCl}_{2}, 0.1 \mathrm{mM}$ EDTA, $1.0 \mathrm{mM}$ DTT and $0.2 \%$ Nonidet P-40). After incubating for five minutes on ice the homogenate was centrifuged at $650 \times \mathrm{g}$ and the pellet was then washed once with buffer $A$. The resulting nuclear pellet was resuspended by gentle pipetting in $300 \mu$ ] buffer $\mathrm{C}$ [ $25 \mathrm{~mm}$ Hepes, $50 \mathrm{mM} \mathrm{KCl}, 0.1$ $\mathrm{mu}$ EDTA $\mathrm{pH} 8.0,1.0 \mathrm{~mm}$ DTT, $10 \%$ (vol/vol) glycerol] and 0.4 $\mathrm{M} \mathrm{NaCl}$. This suspension was incubated for 45 to 60 minutes at $4^{\circ} \mathrm{C}$ followed by centrifugation at $180 \%(1) \times \mathrm{g}$ for 10 minutes. The supernatant collected (nuclear extract) was divided into aliquots and stored at $-70^{\circ} \mathrm{C}$ for subsequent use. To minimize proteolysis, all buffers contained $1.0 \mathrm{~mm}$ Pefabloc, aprotinin $(15 \mu \mathrm{g} / \mathrm{ml})$, leupeptin $(0.5 \mu \mathrm{g} / \mathrm{ml})$. Protcin concentrations were detcrmined by the Bradford assay using the Bio-Rad protein assay reagent. 

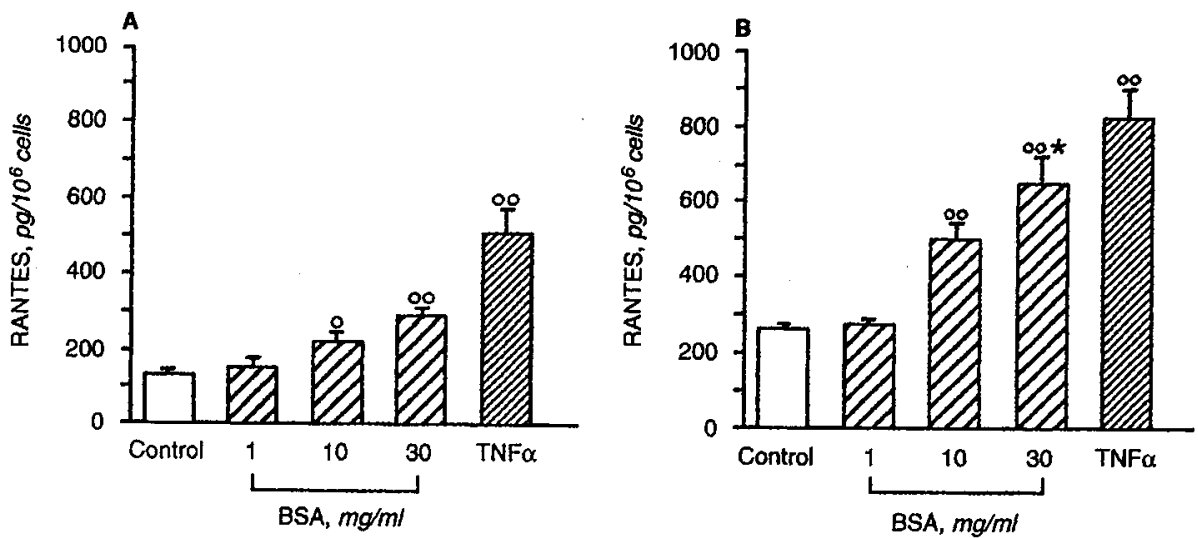

Fig. 1. Effect of increasing concentrations of bovine serum albumin (BSA) on RANTES production by proximal tubular cells. Confluent cells were incubated with control medium or with BSA-containing medium $(\mathrm{t}, 1 \mathrm{n}, 30 \mathrm{mg} / \mathrm{ml})$ for $24(A)$ and $48(B)$ hours. Results are expressed as mean $\pm S E$. ${ }^{\circ} P<0.05$ versus control; ${ }^{\infty} P<0.01$ versus control and $\mathrm{BSA} 1 \mathrm{mg} / \mathrm{ml} ;{ }^{*} P<0.05$ versus $\mathrm{BSA} 10 \mathrm{mg} / \mathrm{ml}$.

\section{Electrophoretic mobility shift and supershift assays}

The $\kappa B$ DNA sequence of the immunoglobulin gene was used for the EMSA ( 5 -CCGGTCAGAGGGGACTTTCCGAGACT). The core $\kappa \mathbf{B}$ sequence is underlined. Oligonuclcotides were synthcsized (Life Technologics/Gibco-BRL, San Giuliano Milanese, Italy) and annealed. Probe DNA (with $S^{\prime}$ overhangs) was end labeled by the kleenow enzyme with $\alpha^{32} \mathrm{P}$ dCTP, and separated from unincorporated nucleotides over a G-50 Scphadex column (Pharmacia Biotech, Uppsala, Sweden).

Nuclear extracts $(2 \mu \mathrm{g})$ were incubated with $50 \mathrm{kcpm}$ of ${ }^{32} \mathrm{P}$ labeled NF- $\kappa$ B oligonucleotide in a binding rcaction mixture [10 $\mathrm{mm}$ Tris- $\mathrm{HCl}$ pH 7.5, $80 \mathrm{~mm} \mathrm{NaCl}, 1 \mathrm{~mm}$ EDTA, $1 \mathrm{~mm}$ dithiothreitol, $5 \%$ glycerol, $1.5 \mu \mathrm{g}$ of poly(dl-dC)] in a final volume of 15 $\mu l$. After 30 minutes on ice the protein-DNA complexes were resolved on a non-denaturing $6 \%$ polyacrylamide gel in $0.5 \times$ Tris-borate-EDTA buffer and run at $200 \mathrm{~V}$ for 1.5 hours at room temperature. Gels were then dricd and subjected to autoradiog. raphy for analysis.

In competition studies, a 1000 -fold molar excess of unlabcled oligonucleotide was added to the binding reaction mixture as indicated, prior to the addition of the labeled $\kappa \mathrm{B}$ probe. In other experiments, to confirm the specificity of binding reaction an excess unlabeled oligonuclcotidc containing an altered sequence of the consensus NF- $k$ B sequence (5'-CCGGTCAGAATTCACTTTCCGAGACT; the altered sequence of the mutated DNA scquence is underlined) was added to the binding seaction mixture prior to the addition of the labeled $\kappa \mathrm{B}$ probe.

For supershift assays, the reaction mixture minus the probe was incubated for one hour on ice with $1 \mu \mathrm{l}$ of affinity-purified rabbit polyclonal antisera specific for p65 (sc-109), p50 (sc-114) or c-Rel (sc-71; all antisera were from Santa Cruz Biotcchnology, Santa Cruz, CA, USA). The labeled NF- $\kappa$ B oligonucleotide was then added, and the incubation was continued at room temperaturc for 20 minutes. Antibodies to individual NF- $\kappa$ B protein subunits may cause either supershift or deplete homodimeric or heterodimeric complexes that bind the radiolabeled oligonucleotides as indicated in several studies $[38-40]$.

\section{Electrun microscopy}

LLC-PK $\mathrm{I}_{\mathrm{I}}$ cultured on filters in hicameral systems for four days after confluency was rcached, were fixed by immersion in $0.5 \%$ glutaraldehyde in $0.1 \mathrm{M}$ phosphate buffered saline (PBS), pH 7.4. Strips of filter of $2 \mathrm{~mm} \times 1 \mathrm{~cm}$ were cut with a razor blade and subsequently postfixed in $1 \%$ osmium tetroxide for 30 minutes. After a bricf wash in PBS they were dehydrated through ascending grades of alcohol and embedded in Epon resin. Sections were cut on an LKB V ultramicrotome. Semithin sections were stained with toluidine blue in borax and examined by light microscopy. Ultrathin sections were stained with uranyl acetate and lead citrate and then examined with a Zeiss EM 109.

\section{Statistical analysis}

Results are expressed as mean \pm sE. Statistical analysis was performed using repeated measures ANOVA and the Duncan test for multiple comparisons, as appropriate [41]. Statistical significance was defined as $P<0.05$.

\section{RESULTS}

\section{Protein overload stimulates RANTES production by proximal} tubular cells

The effect of increasing concentrations of BSA on RANTES production by proximal tubular cells in culture is depicted in Figure 1. After 24 hours of exposure to BSA a dose-dependent increase in RANTES production as compared with cells exposed to medium alone (control) was observed. Actually, RANTES release in supernatants of cells incubated with $1 \mathrm{mg} / \mathrm{ml}$ BSA was similar to control ( $152 \pm 27 \mathrm{vs.} 133 \pm 13 \mathrm{pg} / 10^{\circ}$ cells). By contrast, incubation with 10 and $30 \mathrm{mg} / \mathrm{ml}$ BSA resulted in a progrcssive and significant increase in the chemokine production $(10 \mathrm{mg} / \mathrm{ml}$, $224 \pm 24 ; 30 \mathrm{mg} / \mathrm{ml}, 288 \pm 17 \mathrm{pg} / 10^{6}$ cclls, $P<0.05$ and $P<0.01$ vs. control, respectively). TNF- $\alpha$ was used here as a positive control.

RANTES production further increased after 48 hours, with a trend similar to that obscrved at 24 hours. Thus a significant $(P<$ 


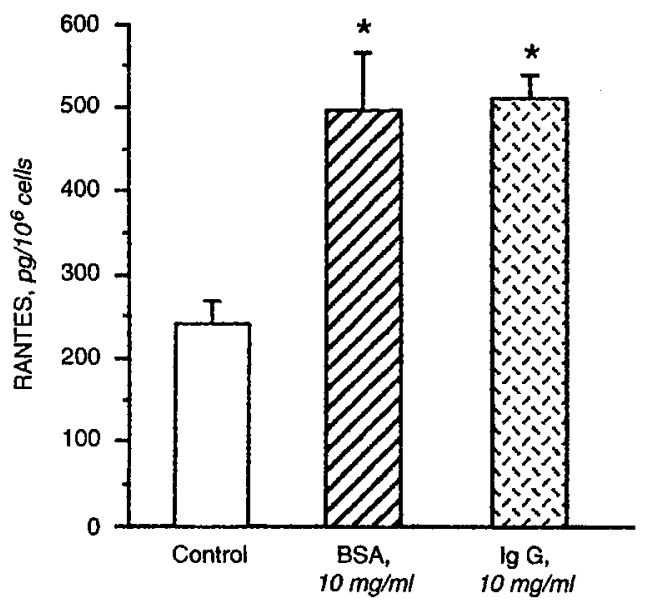

Fig. 2. Effect of proximal tubular cell loading with IgG on RANTES production. Confluent cells werc incubated with control medium or medium containing BSA $(10 \mathrm{mg} / \mathrm{ml})$ or $\mathrm{lgG}(10 \mathrm{mg} / \mathrm{ml})$ for 48 hours. Results are expressed as mean $\pm \mathrm{se}$. $* P<0.01$ versus control.

0.01) increase in RANTES was obscrved with 10 and $30 \mathrm{mg} / \mathrm{ml}$ BSA $(10 \mathrm{mg} / \mathrm{ml}, 498 \pm 43 ; 30 \mathrm{mg} / \mathrm{ml}, 650 \pm 72$ vs. cuntrol, $256 \pm$ $19 \mathrm{pg} / 10^{6}$ cclls).

To establish whether the stimulatory effect of albumin on RANTES production by proximal tubular cells were attributable to its lipid component, cells were exposed for $\mathbf{4 8}$ hours to fatty acid-free BSA $(10 \mathrm{mg} / \mathrm{ml})$ or to BSA $(10 \mathrm{mg} / \mathrm{ml})$. Results showed that fatty acid-free BSA and BSA stimulated RANTES release to a comparable extent ( $537 \pm 52$ vs. $529 \pm 32 \mathrm{pg} / 10^{6}$ cells), thus indicating that the lipid component of the molecule is not involved in the observed phenomenon.

The effect of increasing RANTES synthesis was not confined to albumin but was also apparent when proximal tubular cells were exposed to higher than normal concentrations of proteins like $\mathrm{IgG}$ (Fig. 2). Thus, as observed for BSA, $10 \mathrm{mg} / \mathrm{ml} \mathrm{IgG}$ significantly $(P<0.01)$ increased RANTES production after a 48-hour incubation $\left(510 \pm 27 \mathrm{pg} / 10^{6}\right.$ cells vs. control, $242 \pm 27 \mathrm{pg} / 10^{6}$ cells).

\section{Polarized secretion of RANTES by proximal tubular cells exposed to protein overload}

Since in vivo tubular epithelial cells are organized as a continuous polarized cell layer that serves to separate apical and basolateral compartment with different specific activity [42], here we investigated whether tubular production of RANTES werc polarized toward the basolateral compartment. Proximal tubular cclls grown on filters in bicameral systems became organized in a polarized cell monolayer as assessed by electron microscopy examination (Fig. 3). LLC-PK 1 cells presented microvilli on the apical membrane and adjacent cells exhibited marked lateral intercellular djgitations and well-developed tight junctions in the basolateral domain.

As shown in Figure 4, RANTES production by control tubular epithelial cells was polarized in that RANTES release, after 48 hour incubation with medium alone, was significantly higher in the basolateral compartment in respect to the apical side (228 $\pm 19 \mathrm{vs}$. $80 \pm 6 \mathrm{pg} / 10^{6}$ cclls, $\left.P<0.05\right)$. Apical exposure to BSA $(10 \mathrm{mg} / \mathrm{ml})$ for 48 hours significantly increased tubular basolateral release of RANTES in respect to control condition ( $488 \pm 48$ vs. $228 \pm$ $19 \mathrm{pg} / 10^{6}$ cells, $P<0.01$ ). In the apical compartment of BSAstimulated cells RANTES protein values were numerically higher than those of control cells, but the statistical significance was not reached $\left(139 \pm 10\right.$ vs. $80 \pm 6 \mathrm{pg} / 10^{6}$ cells $)$

\section{Protein overload activates the transcriptional factor NE- $\ll B$ in proximal tubular cells}

Nuclear extracts preparared from LLC-PK, cells were assayed for activated NF- $\kappa \mathrm{B}$ in an electrophoretic mobility shift assay of DNA binding factors using a radiolabeled consensus sequence $\star B$ probe containing the core $\mathrm{\kappa B}$ site GGGACTTTCC. As shown in Figure 5 nuclear extracts from control cells formcd two faint bands: an upper complex (complex I) and a faster migrating lower complex (complex II). The same pattern was observed with serum starved cells (data not shown). Incubation of proximal tubular cells with 10 and $30 \mathrm{mg} / \mathrm{ml}$ BSA for 30 minutes elicited a substantial rise in NF- $\mathrm{B}$ DNA binding activity of complex I and II in a dose-dependent fashion and the appearance of a new band (complex III) that migrated closely to complex II. TNF- $\alpha$, a strong inducer of $\mathrm{NF}-\kappa \mathrm{B}$ activation $[21,23]$, was used as positive control. Treatment of cells with the NF-KB inhibitor PDTC $(25 \mu \mathrm{M})$ resulted in inhibition of BSA-induced NF- $\kappa \mathrm{B}$ activation (Fig. 5).

The specificity of the binding reaction was confirmed by the ability of cxcess unlabeled (cold) NF- $\kappa$ B oligonucleotide to inhibit binding (Fig. 6). When an exccss unlabeled oligonucleotidc containing an altered sequence of the consensus NF- $\kappa$ B sequence was used as irrelevant oligonucleotide, it did not affect the binding of the specific $\kappa B$ probe to nuclear proteins (not shown).

The composition of activated NF- $k$ B was investigated by antibody EMSA (supershifts) with nuclear extracts of cells incubated with $30 \mathrm{mg} / \mathrm{ml} \mathrm{BSA}$. The pattern shown in Figure 6 was reproduced in three independent experiments employing different nuclear extracts. The upper band, complex $I$, consisted of two forms p65/p65 homodimer and p65/cRel heterodimer, since antibody against $\mathrm{p} 65$ almost completely abolished the entire complex and caused further gel retardation (supershift), while anti-cRel antibody determined a signal reduction of the band. When both antibodies were added simultaneously the complex I disappeared completely. The apparent diminution of signal intensity in band I (lane $\alpha p 50$ ) was not seen in repeated experiments and is probably due to slight underloading of probe or protein in that lane. Complex II was inhibited by both anti-p50 and anti-cRel antibodies but not by anti-p65 antibody, suggesting that the complex represented $\mathrm{p} 50 / \mathrm{cRel}$ heterodimer. Finally, complex III represcntcd p50/p65 heterodimer. Pre-incubation of the cells with anti-p50 antibody consistently reduced the intensity of the complex in all the performed experiments, while anti-p65 antibody abolished it. Combination of the two antibodies resulted in the complete disappearance of the complex III. Cclis challenged with TNF- $\alpha$ promoted the activation of the same NF- $k$ B/Rel subunits (data not shown). 


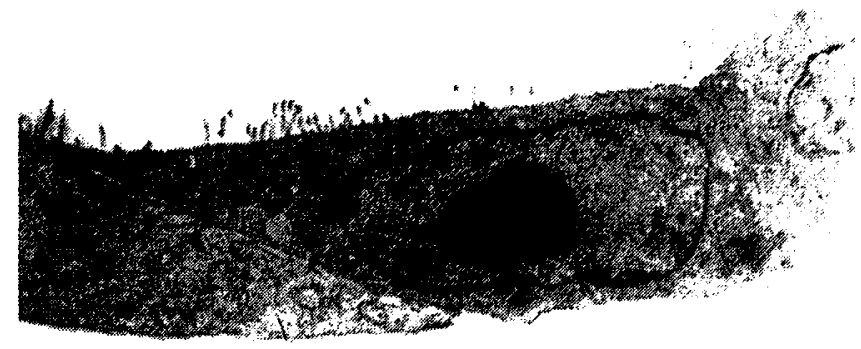

Fig. 3. Electron micrograph of LLC-PK, cells grown in a bicameral system for four days after reaching confluence. Cells show clcar polarization with an apical domain bearing microvilli and a basolateral domain showing well-defined tight junctions (origina! magnification $\times 3.000)$.

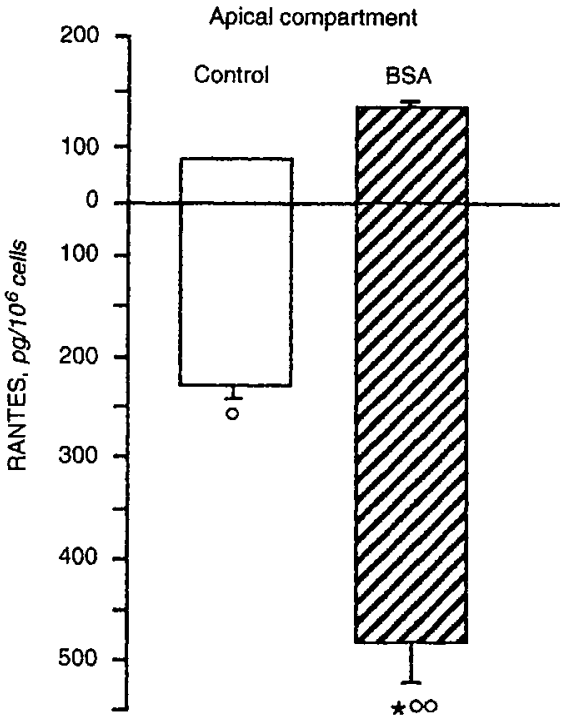

Basolateral compartment

Fig. 4. Polarized production of RANTES by proximal tubular cells after apical exposure to BSA for 48 hours. Cells were grown on a Transwell chamber for four days ufter reaching contluence. Then medium was removed and control medium or BSA-containing medium $(10 \mathrm{mg} / \mathrm{ml})$ was added to the upper chamber, while medium alone was added to the lower chamber. Results are expressed as mean \pm St: ${ }^{\circ} P<0.05,{ }^{\infty} P<0.01$ versus corresponding apicul compartments; ${ }^{*} P<0.01$ versus contrul basolateral compartment.

Protein overload-induced RANTES production is dependent by NF-אB activation

To evaluate a possible rolc of NF-kB activation on BSAinduced RANTES production, proximal tubular cells were treated with the NF- $\kappa$ B inhibitors PDTC $(10,25 \mu \mathrm{M})$ and sodium salicylate $(5,10 \mathrm{~mm})$ one hour prior and during 48 hour incubation with BSA (10 mg/ml). As reported in Table I both PDTC (at 25 $\mu \mathrm{M}$ ) and sodium salicylate (at $10 \mathrm{~mm}$ ) completely inhibited the stimulatory effect of BSA on tubular RANTES production.

\section{DISCUSSION}

Despite the recent cxperimental and clinical evidence quite convincingly documenting that protein trafficking through the glomerular capillary has an intrinsic tenal toxicity $[2,43]$, the intimate mechanism(s) of protein-induced damage is only beginning to be explored. Data are already available proving that overexposure to filtcred protcins during the process of reabsorption induces proximal tubular cells to up-regulate genes for vasoactive and inflammatory mediators such as ET-1 and MCP-1 $[11,14]$, which may play a major role in the interstitial inflammatory rcaction that invariably follows initial lesion in proteinuric glomerulopathies [2]. There is also in vivo evidence that the corresponding protein products are indeed frequently released into the renal interstitium $[44,45]$ where they contribute to peritubular capillary ischemia and inflammatory cell recruitment. Here we report that exposure of proximal tubular cells in culture to albumin and other proteins causes a concentration and time dependent increase in the production of RANTES, a member of immunoregulatory chemokines with powerful chemotactic properties for monocytes and memory T-cells $[25,26]$. The relevance of thcse findings to the pathophysiology of progressive nephropathies in the context of protein toxicity rests on the recent demonstration that RANTES plays a pivotal role in acute and chronic inflammatory responses, and may therefore take an active part in the development of tubulointerstitial lesions of progressive nephropathies [31]. Due to the fact that monocytes and $T$ lymphocytes are the major cellular component of inflammatory reaction that follows protein overabsorption, we addressed the possibility that the secretion of RANTES by proximal tubular cells wcre polarized toward the aspects of cells in intimate contact with the interstitium. Our data show that, at least in vitro, the large majority of secreted RANTES goes into the basolateral compart. ment of the cells. If this occurred in vivo, it means that RANTES generated in response to protein overload accumulates into the interstitial space. Given its potent and sclective chemotactic properties on those cells that characteristically predominate in the interstitium during the course of progressive nephropathies, a contribution of RANTES in cell recruitment and a subsequent fibrosis is very likely.

The transcription of RANTES is regulated in a complex manner by diverse control mechanisms in different tissucs [27]. 

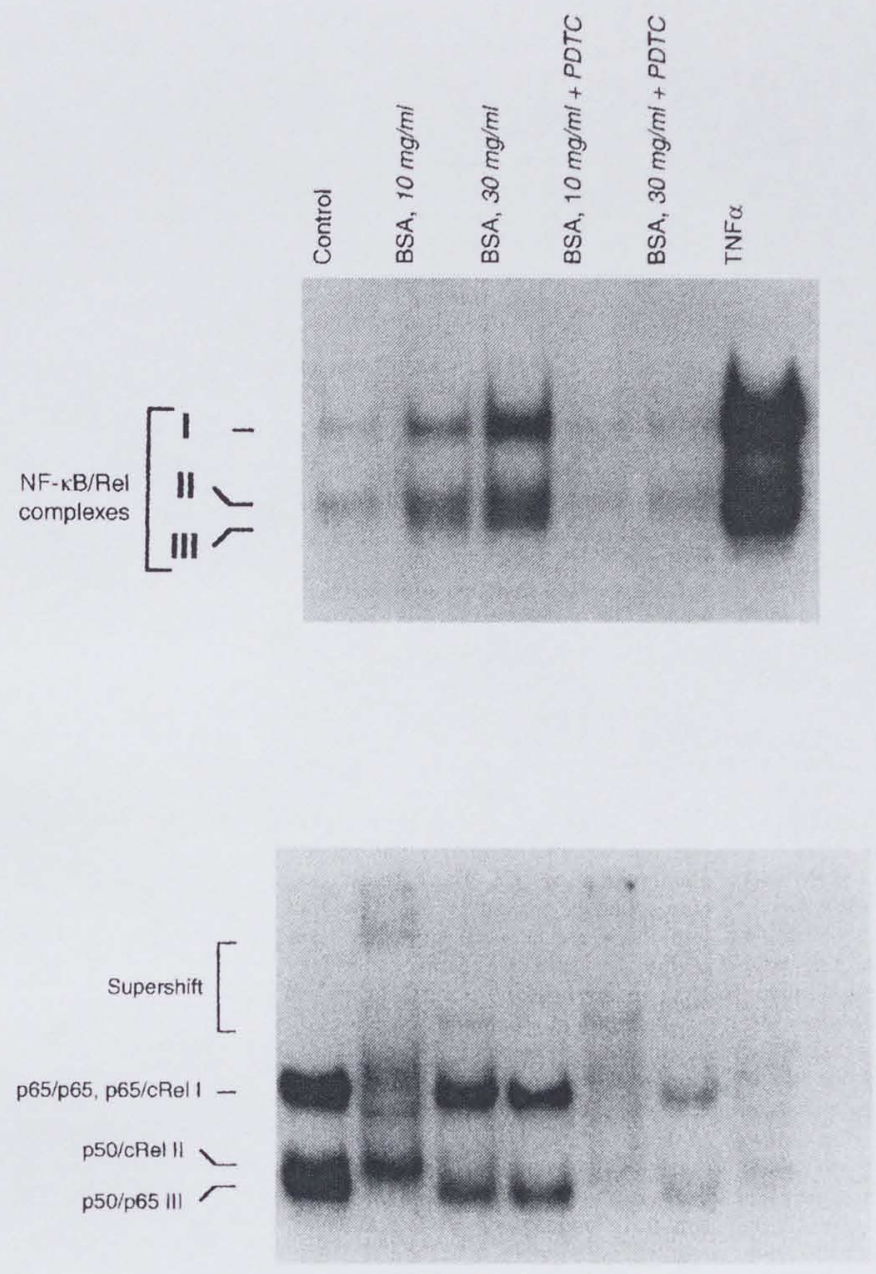

Fig. 5. Electrophoretic mobility shift assay (EMSA) for NF- $\boldsymbol{B}$ B activity in nuclear extracts from LLC.PK, cells exposed for $\mathbf{3 0}$ minutes to medium alone (control), BSA $(10,30 \mathrm{mg} / \mathrm{ml})$, BSA plus PDTC $(25 \mu \mathrm{M}$, added 1 hour before the addition of BSA), or TNF- $\alpha(100 \mathrm{U} / \mathrm{ml})$ as positive control. Complexes I, II, III denote the inducible $\kappa \mathrm{B}$ specific DNA-protein complexes. The results shown are representative of three independent cxperiments.
Fig. 6. Subunit composition of NF- $-\kappa \mathrm{B}$ activated by proximal tubular cell exposure to an high concentration of BSA. AntibodyEMSAs were performed with nuclear extracts of LLC-PK cells treated with BSA $(30 \mathrm{mg} / \mathrm{ml})$ for 30 minutes. Nuclear extracts were incubated with antibodies against p50 ( $\alpha$ p50), p $5.5(\alpha$ p65), and cRel ( $\alpha \mathrm{cRel}$ ) subunits to verify the identity of the BSA-activated NF- $k$ B. Antibody supershifts produced by binding of the antibody to the Rel protein-DNA complex are indicated. To demonstrate the specificity of binding of the $\mathrm{NF}-\kappa \mathrm{B}$ oligonucleotide, 1000 -fold molar excess unlabeled NF- $\mathrm{BB}$ (cold) was used to compete with the labeled NF- $\kappa$ B probe for binding to BSA-induced nuclear proteins. The results shown are representative of three independent experiments cmploying different nuclear extracts.
Actually, the 5'-flanking region of the RANTES gene contains binding sites for transcriptional factors, one of which, NF- $\kappa \mathrm{B}$, is associated with rapid activation mechanisms [33]. NF- $\mathrm{KB}_{\text {consists }}$ of protein homodimers or heterodimers belonging to the $\mathrm{Rel}$ family $[46,47]$ and exists in an inactive form in the cytoplasm of cell bound to the inhibitory protcin $I_{\kappa} \mathrm{B}[22,46]$. Activation of $\mathrm{NF}-\kappa \mathrm{B}$ by appropriate triggers, which include cytokines, activators of protein kinase $\mathrm{C}$, viruses, and oxidants [23], promotes nuclear translocation of the DNA-binding subunits after they are released from $1 \kappa \mathrm{B}$. NF- $\kappa \mathrm{B}$ controls the transcription of a number of proinflammatory genes [23] involved in the pathogenesis of glomerular and tubular disease and of great interest is the recent evidence of in vivo $\mathrm{NF}-\kappa \mathrm{B}$ activation in kidneys from rats with
anti-GBM glomerulonephritis [48] and unilateral ureteral obstruction [40].

Herc we examined whether excessive synthesis of RANTES by proximal tubular cells in response to protein stress were dependent on NF- $\kappa \mathrm{B}$ activation. Our data documented that exposure of proximal tubular cells to increasing concentrations of albumin induced a dose-dependent increase in NF- $\kappa \mathrm{B}$-DNA binding activity, which was effectively and completely blocked by specific inhibitor interfering with pathways leading to $I \kappa \mathrm{B}$ degradation. Since distinct combinations of $\mathrm{NF}-\kappa \mathrm{B} / \mathrm{Rel}$ subunits bind with different affinities to the $\mathrm{kB}$ sites eliciting different transcriptional responses [49], this study additionally investigated the composition of NF-kB subunits that were activated by protein overload. 
Table 1. Effect of NF- $k \beta$ inlibitors on BSA-induced RANTES production in proximal tubular cells

\begin{tabular}{|c|c|}
\hline & $\begin{array}{l}\text { RANTES } \\
p \mathrm{~g} / / \|^{\alpha} c c^{\prime} / l s\end{array}$ \\
\hline Control & $260.2 \pm 22.8$ \\
\hline BSA & $475.2 \pm 33.3^{\prime \prime}$ \\
\hline $\mathrm{BSA}+\operatorname{PDTC}(10 \mu \mathrm{u})$ & $378.7 \pm 54.4$ \\
\hline BSA + PDTC $(25 \mu \mathrm{s})$ & $174.9 \pm 9.2^{\mathrm{b}}$ \\
\hline $\mathrm{BSA}+\mathrm{NaSal}(5 \mathrm{~mm})$ & $482.0 \pm 71.1$ \\
\hline $\mathrm{BSA}+\mathrm{NaSal}(10 \mathrm{~mm})$ & $141.0 \pm 42.0^{\prime \prime}$ \\
\hline
\end{tabular}

BSA was used at $10 \mathrm{mg} / \mathrm{ml}$ for 48 hours. Abbreviations are: BSA, hovine serum albumin; PDTC, pyrrolidine dithiocarbamate; NaSal, sodium salicylate. Data are expressed as mean $\pm \mathrm{st}$ :

a $P<0.01$ vs. cuntrol

' $P<0.01$ vs. BSA

We found that resting LLC-PK, presented two faint bands consisting of the homodimer p65/p65 and the heterodimer p65/ cRel complex I and the heterodimer p50/cRel complcx II. At variance with this finding, after exposure of proximal tubular cells to protein overload, another complcx (complcx III) appeared that represented the heterodimer $\mathrm{p} 50 / \mathrm{p} 65$. A similar pattern of NF- $\kappa B$ activation was obscrved upon challengc of proxima! tubular cells with TNF- $\alpha$, which is a potent promoter of the cxpression of several inflammatory genes $[50,51]$.

As for the RANTES gene, another NF- $\mathrm{B}$-dependent gene MCP-1 $[19,20]$ can be rapidly induced in rat proximal tubular cells in culture by high concentrations of either albumin or transferrin [14]. It is therefore rcasonabic to assumc that overloading proximal tubular cclls with various proteins results in a common pathway of activation of NF- $\kappa \mathrm{B}$-dependent genes whose protein products could collcctivcly play a determining role in recruiting inflammatory ccls into renal interstitium. We performed additional experiments aimed at exploring the possibility that increased synthesis of RANTES by proximal tubular cclls in response to protein overload were indeed dependent on NF- $k B$. Findings that specific inhibitors of NF- $\mathrm{B}$ activation fully eliminate the property of albumin of inducing RANTES synthesis by cultured tubular cells provide compclling cvidence to implicate NF- $\kappa$ B activation pathway as a common cellular mechanism capable of up-regulating genes encoding inflammatory and possibly vasoactive products in response to protein stress. Accumulation of these mediators into the renal interstitium could well be the initial trigger of the complex process that translates glomerular permeability dysfunction into cellular signals of interstitial inflammation, and eventually determines progression of renal diseases to end-stage renal failure. Induction of RANTES upon protein overreabsorption is not limited to cells in culture. A recent study has documented that RANTES gene was up-regulated in the kidneys of mice with crescentic glomerulonephritis that were markedly proteinuric and that the administration of a RANTES antagonist partially reduced proteinuria and limited glomerular and interstitial accumulation of $T$ cells and monocyte/macrophages [3]].

In summary, we have found that the process of tubular epithelial cell activation in responsc to protein loading includes an enhanced synthesis rate of the potent inflammatory chemokine RANTES. Up-regulation of RANTES in response to protein stress is accompanied by activation of the transcription factor $\mathrm{NF}-\kappa \mathrm{B}$ and can be fully suppressed by $\mathrm{N} \mathrm{F}^{-} \kappa \mathrm{B}$ inhibitors. These data identify a novel mechanism, which may not be confined to RANTES, by which the process of reabsorption of fitered proteins activates proximal tubular epithelium, and thus cxplains in biochemical terms the renal toxicity of protein trafficking.

On the basis of these findings one can foresee novel strategies to prevent renal disease progression by targeting one of the complex mechanisms of NF- $\kappa \mathrm{B}$ activation [23]. Exogenous inhibitors with antioxidant activity are beginning to be studied with this indication and will probably be available as drugs in the near future [52]. By a gene therapy approach, inhibitory genes like ] $\mathrm{kB}$ [53] could hopefully be transferred to target cells to ultimately prevent proximal tubular cell activation and the coordinated expression of proteins with inflammatory properties.

\section{ACKNOWLEDGMENTS}

Part of this work was presented at the 30th Annual Meeting of the American Society of Nephrology (San Antonio, Texas, Novcmber 2-5, 1997). We are decply indebted to Prof. Detlef Schlondorff and to Dr. Pcter Nelson for their envaluable help in selting up the EMSA method. We thank Dr. Mauro Abbate and Maria Enrica Bonassi for electron microscopy studies and Federica Casiraghi for excellent technical assistance. Dr. Roberta Donadclli is recipient of a fellowship from "Collegio dei Ragionieri e Periti Commerciali di Bergamo"; Dr. Stella Colleoni is a recipicnt of an award from "L.Ago Magico".

Reprint requests to Carta Zoja, Biol.Sci.D., Laboratory of Experimemal Models and Cell Cullures for Kidncy Disenses, Mario Negri Invtitute for Pharnacological Research, Via Gavazzeni 11, 24125 Bergamo, Rah.

\section{APPENDIX}

Abbreviations used in this article are: BSA, hovine serum albumin; ELISA, enzyme linked-immunosorbent assay; EMSA, electrophoretic mobility shift assay; ET-1, cndolhelin-1; FCS, fetal calf serum; IgG, immunoglobulin G; JL, interleukin; LPS, lipopolvaccharide; MCP-I monocyte chemoattractant protein-1; NF- $\kappa$ B, nuclear factor- 8 ; PBS, phosphate buffered saline; PDTC, pyrrolidinc dithiocarbamate; RANTES. regulated upon activation, normal I cell expressed and secreted; TNF+c $\alpha$, tumor necrosis factor $-\alpha$.

\section{REFERENCES}

1. RemuZZI G. Bertanl $T$ : Is glomerulosclerosis a consequence of altcred giomcrular permeability to macromolecules? Kidney In 36 : $384-394,1990$

2. REmuzzI G, RugGenenti P, BenIGN\} A: Understanding the nature of renal disease progression. Kidncy lot 51:2-15, 1997

3. Remuzz. G: Abnormal protein traffic through the glomerular hitrricr induces proximal tubular cell dysfunction and causes renal injury. Cun Opin Nephrol Hypertens 4:339-342, 1995

4. DAVIFS DJ, BRFwFr DB. HARDwICKE J: Urinary proteins and glomerular norphometry in protein overload proteinuria. Lab lniest 38:232-243, 1978

5. WeEning JJ, Vay Guldenek C, Daha MR, Klak N. Van Den Wal A, Prins FA: The pathophysiology of protein-overload proteinuria. Am J Pathol 129:64-73. 1987

6. EDDY AA. MCC.uloCh I., Arsans J. J.u E: Interstitial nephritis induced by protein-overload proteinuria. An J Pathol 135:719-733. 1989

7. Moki H, Yamasilta $H$, NAknvishi $C$, Kolzumi $K$, Makino $S$. KJSHImoto Y, HaYash! Y: Proleinuria induced by transplantable ral pituitary lumor MtT SAS. Model for humologous protein overload proteinuria. Lab Invest $54: 636-644,1986$

8. Eory AA: Experimental insights into the tubulointersticial discase accompanying primary glomerular lesions. $J .4 m$ Soc Nephrol 5:12731287, 1994

9. Kuvnes EJ: Fibrogenic sytukines: The role of immune mediators in the development of scar tissuc. Immand Today 12:17-23. 1991 
10. Aivarez RJ, Sun MJ, Haverty TP, IOzZo RV, MYYRS JC, Neilsow EG: Biosynthetic and proliferative characteristics of tubulointerstitial fibroblasts probed with paracrine cytokines. Kidn' ' (n) 41:14-23, 1992

11. Zuja C, MORIGI M, FigliuzzI M. BruzzI I, Oldroyd S, Benigini A, Ronco PM, Remizzi G: Proximal tubular cell synthesis and secretion of endothelin-1 on challenge with albumin and other proteins. Am $J$ Kidney Dis 26:934-947, 1995

12. ONG AC, JOWETT TP, MOORHEAI JF, OWHN JS: Human high density lipoproteins stimulate endothelin-1 release by cultured human renal proximal tubular cells. Kidney Int 46:1315-1321, 1994

13. KeEs-Fol.ts D, Sabow JL. Schreivf: GF: Tubular catabolism of albumin is associated with the release of an inflammatory lipid. Kidney Int 45:1697-1709, 1994

14. WhNg $Y$, Chen J, Chen L, TAY Y.C, Rangan GK, Harris DCH Induction of monocyle chemoattractant protein-1 in proximal tubulc cells by urinary protein. $J A m$ Soc Nephrol 8:1537-1545, 1997

15. ACHMAD TH. Rno GS: Chemotaxis of human blood monocytes toward endothelin-1 and the influence of calcium channel blockers. Biochem Biophys Res Commun 189:994-1000, 1992

16. Ong; ACM, Jowett TP, FirTh JD, Burion S, KITMMURa M, Fine LG: A new paracrine loop implicated in human tubulo-interstitial fibrosis: Tubular-derived cndothelins modulate renal interstitial fibroblast function. (abstract) J Am Soc Nephrol 4:473, 1993

17. I.FONARD EJ, YOSHIMLKA T: Human monocyte chemoattractant protein-1 (MCP-1). Immunol Today 11:97-101, 1990

18. Carr MW, Roth SJ, LuthfFr E, Rose SS, Springier TA: Monocyte chemoattractant protcin-1 acts as a $T$-lymphocyle chemoattractant Proc Nal Acad Sci USA 91:3652-3656, 1994

19. ROVIN BH, DICKERSON JA, TAN LC, HEBfKr CA: Activation of muclcar factor- $\kappa \mathrm{B}$ correlates with MCP-1 expression by human mesangiat cells. Kidney $m t+8: 1263-1271,1995$

20. Ueva A, Okuda K, Ohno $S$, Shirai A, IGarashi T, Matsunaga $K$ Fuklsilima J, Sawamotu $S$, Ishigatsubo Y, OKUbo T: NF-kB and Spl regulate transcription of the human monocyte chemoatiractane protein-1 gene. I Lnmmol 153:2052-206.3, 1994

21. BAEUERLE PA, HHNKEL T: Function and activation of NF- $\kappa \mathrm{B}$ in the immune systcm. .4mmu Rev Immunol 12:141-179, 1994

22. Henkel T, Machleidt T, Alkalay I, Kronki: M, Ben-Neriah Y, BAEUERLF. PA: Rapid proteolysis of $I k B-\alpha$ is necessary for activation of the transcription factor NF-кB. Nature 365:182-185, 1993

23. BAR.VES PJ, KARIR $M$ : Nuclear factor $-k B-A$ pivotal transcription factor in chronic inflammatory diseases. $N$ Engl J Med 356:1066-1071, 1997

24. Pahl HL, Bafuert.t. PA: A novel signal transduction pathway from the endoplasmic reticulum to the nucleus is mediated by iranscription faclor NF-кB. EMBO J 14:2580-2588, 1995

25. Oppfanhlim Jj, Zachariae CO, Mukaida N, Matsushima K: Prop crties of the novel proinllammatory supergene "intercrine" cytokine family. Anm Rev Immunol 9:617-648, 1991

26. SCHALL TJ, BACON K, TOY KJ. GOEDDEL DV: Sclective attraction of monocytes and $T$ lymphocytes of the memory phenotype by cytokine RANTES. Nature 347:669-671. 1990

27. Wulf G, Luckow B, SchlondorfF D: Molecular biolugy and function of the chemuattractant cytokines RANTES and CSF-1, in $M O$ lecular Neplirology. Kidney Function in Heallh and Disease, edited by SChlonisorfF D, Bonventre JV, New York, Marcel Dekker, Inc., 1995. пp 673-679

28. Wolf G, Aberle S, Thaiss F, Nelson PJ, Krensky aM, Neilson EG. STAHL RAK: TNF $\alpha$ induces expression of the chemoattractant cytokine RANTES in cultured mouse mesangial cclls. Kidhey $\mathrm{ht}$ 44:795-804, 1993

29. HEEGEK P, WOIF G, MFYERS $C$, SUN MI, O'FARRELL SC, KRENSKY AM, NEILSON EG: Isolation aud characterization of cDNA from rcnal tubular epithelium encoding murine Rantes. Kidney $h 11$ 41:220-225. 1992

30. Satrlano Ja, Banas B, luckow B, Nizson P, ScillondorfF D: Regulation of RANTES and $1 C A M-1$ expression in murine mesangial cclis. J Am Soc Nephrol 8:596-6013, 1997

31. Lioyd CM, Minto AW, DORF ME, Prounfout A, Wlils TNC, SAlANT DJ, GUTIERREZ-RAMOS J-C: RANTES and monocyte chemoattractant protein-1 (MCP-1) play an important role in the inflanmatory phase of crescentic nephritis, but only MCP-1 is involved in crescent formation and interstitial fibrosis. J Exp Med 185:1371-1380, 1997

32. Ral HP, Tilaiss F, Wolf G, Zahnek G, Neison P, KRensky A SCHOEPSE W, STAHL RAK: Prostaglandin E] reduces the expression of the chemokine RANTES in glomeruli of rats with immune mediated mesangial celi injury. (abstract) $J$ Am Soc Nephrol 44:629. 1993

33. NELSON PJ, KIM HT, MANNSNG WC, GORALSKJ TJ, KRENSKY AM Genomic organization and transcriptional regulation of the RANTES chemokine genc. $J$ Immunol 151:2601-2612, 1993

34. HLLL RN, CHERRY WR, WEAVER GW: The origin and characterization of a pig kidney cell strain, LLC-PK1. In Vitro 12:670-677, 1976

35. LANDWEHR DM, CARvalho JS, OKEn DE: Micropuncture studies of the filtration and absorption of albumin by nephrotic rats. Kidney Int $11: 9-17.1977$

36. Korp $E$, GHost $S$ : Inhibition of NF- $\mathrm{BB}$ by sodium salicylate and aspirin. Science 265:956-959, 1994

37. SATRIANO J, ScitiondorfF D; Activation and attenuation of transcription factor NF-kB in mouse glomerular mesangial celts in re sponse to tumor necrosis factor- $\alpha$, immunoglobulin $\gamma$. and adenosine $3^{\prime}: 5^{\prime}$-cyclic monophosphatc. J Clin Invest 94:1629-1636, 1994

38. Nilson PJ, ORTIZ BD, PATTISON JM, KRFNSKY AM: Identification of a novel regulatory region critical for expression of the RANTES chemokine in activated T lymphocytes. J Inmunol 157:1139-1148, 1996

39. JOHNSON DR. DOUGilas I, JaHnkf A, Ghosh S, POBER JS: A sustained reduction in $I_{\kappa} B-\beta$ may contribute to persistent $N F-\kappa B$ activation in human endothelial cells. J Biol Chen 271:16317-16322, 1996

40. Morrissey JJ, KI.AHR S: Enalapril decreases nuclear factor $\kappa \mathrm{B}$ activation in the kidney with ureteral obstruction. Kidney Int 52:926933,1997

41. WALLFins rein S, ZUCKER CL, Fleiss JL: Some statistical methods use[ul in circulation research. Circ Res 47:1-9, 1980

42. FiSH EM, MoLTTORis BA: Adtcration in epithelial polarity and the pathogenesis of discase states. $N$ Engl $J$ Med 330:1580-1588, 1994

43. BENIGNI A, ZOJA C, Rt,MUZZI G: Biology of disease. The renal toxicity of sustained glomerular protein traffic. Lab Imvest 73:451-468, 1995

44. Bruzzi ], Corna D, Zuha C, Orisio S, Schiffrin EL, Cavallotti D, REMIIZZI C, BrNiciN A: Time course and localization of endothelin-1 genc expression in a model of renal disease progression. Am $J$ Palhol 151:1241-1247, 1997

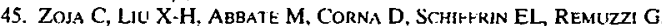
BENIGNI A: Angiotensin It blockade limits tubular protein overreabsorption and the consequent up-regulation of endothelin-1 genc in experimental membranous nephropathy. Exp Nephrol (in press)

46. BALDWIN AS: The NF-kB and I $\mathrm{B}$ proteins: New discoveries and insights. Annu Rev Immunol 14:649-681, 1996

47. Verma IM, Stevenison 3K, Schwarz EM, Van ANIWERp D, MiYAMoro S: Rel/NF- $\kappa \mathrm{B} / \mathrm{l}_{\kappa} \mathrm{B}$ tamily: Intimate tales of association and dissnciation. Genes Dev 9:2723-2735, 1995

48. Sakural H, Hisada Y, Uheno M, Sugllira M, Kawashima K, SugtTa $T$ : Activation of transcription factor $\mathrm{NF}_{-} \kappa \mathrm{B}$ in experimental giomeruluncphritis in rats. Biochim Biophys Acta 1316:132-138, 1996

49. PfRkins ND, SCHMID RM, DUCKF,2T CS, LEUNG K, RICF: NR, NABz:1 GJ: Distinct combinations of NF- $\kappa$ B subunits determine the specilicity of transcriptional activation. Prre Nat Acad Sci USA 89:1529-1533, 1992

50. Satriano Ja, Hoka K, Shan Z, Stanley ER, MOKI T, Schlondorff $D$ : Regulation of monocyte chemoattactane protein-1 and macrophage colnny-stimulating factor- 1 by IFN- $\gamma$, tumor necrosis factor- $\alpha$, IgG aggregates, and cAMP in mouse mesangial cells. $J$ Immumol 150:1971-1978, 1993

51. Coilins T, Read MA, Neish as, Whith ey MZ, Thanos D, Maniaris $T$ : Transcriptional regulation of endothelial cell adhesion mole cules: $\mathrm{NF}+K \mathrm{~B}$ and cytokine-inducible enhancers. F.4SEB J 9:899-909, 1995

52. SCHRECK R, RiEBER P. BaEUERLF PA: Reactive oxygen intermediates as apparently widely used messengers in the activalion of the NF-kB Iranscription factor and HIV-1, EMBO J 10:2247-2258, 1991

53. Wrighton CJ, Hofer-Warbinek R, MOI.I. T. EYINLK R, Bach FH, DE MARTIN R: Inhibition of endothelial cell activation by adenovirusmediated expression of $1 \kappa \mathrm{K} \alpha$, an inhibitor of the transcription factor NF-кB. J Exp Med 183:1013-1022, 1996 


\section{CHAPTER 3}

\section{Protein traffic activates NF-kB}

\section{gene signaling and promotes MCP-1 dependent interstitial inflammation}

R. Donadelli, M. Abbate, C. Zanchi, D. Corna, S. Tomasoni, A. Benigni, G. Remuzzi, and C. Zoja American Journal of Kidney Diseases 2000; 36:1226-1241 


\title{
Protein Traffic Activates NF-kB Gene Signaling and Promotes MCP-1-Dependent Interstitial Inflammation
}

\author{
Roberta Donadelli, BiolSciD, Mauro Abbate, MD, Cristina Zanchi, Chemist, \\ Daniela Corna, Chemist, Susanna Tomasoni, BiolSciD, Ariela Benigni, BiolSciD, \\ Giuseppe Remuzzi, MD, and Carla Zoja, BiolSciD
}

\begin{abstract}
- Mononuclear cells accumulate in the renal interstitium and contribute to renal injury in proteinuric nephropathies. Anglotensin-converting enzyme (ACE) inhlbitors reduce protein trafficking and also lessen renal structurad and functional damage. Many proinflammatory genes, including monocyte chemoattractant protein-1 (LCP-1), a chemoattractant for monocytes and $T$ lymphocytes, are transcriptionally regulated by nuclear factor-kappa $B$ (NF-kB). We aimed to study NF-kB activation and MCP-1 expression oves time in two modeis of progressive proteinuric nephropathles (5/6 nephrectomy and passive Heymann nephritis (PHW]) and ovafuate the effect of antiprotelnurlc therapy with an ACE inhibitor on thase factors. in both models, increased urinary proteln excretion over time was associated with a remarkable increase in NF-kB activlty, which was aimost completely suppressed by reducing protoinuria with lisinopril. NF-KB activation was paralleled by upregulation of MCP-1 messenger RNA and Interstitial accumulation of ED-1-positive monocytes/macrophages and CD8-positive T cells. Lisinopril inhibited MCP.1 upregulation and limited interstitial Infiammation. In a group of PHN rats with advanced disease and severe proteinuria, a dose of lisinopril high enough to inhibit renal ACE activlty failed to reduce protelnuria and also did not limit MF-kB activation, which was sustained over time, along with MCP.1 gene overexpression and interstitial Inflammation. These data suggest that NF.kB is activated in the presence of increased protein trafic, enhancing the nuclear transcription of the MCP-1 gene with potent chemotactic and inflammatory properties. This mechanism may help explain the long-term renal toxicity of fitered proteins.
\end{abstract}

2000 by the National Kidney Foundation, Inc.

INDEX WORDS: Proteinurla; nuclear factor kappa B (NF *B) activation; monocyte chemoattractant protein-1 (MCP-1); interstitial inflammation; anglotensin-converting enzyme (ACE) inhibitor.

C HRONIC NEPHROPATHIES with highly enhanced glomerular permeability to proteins are accompanied by tubulointerstitial inflammation and scarring responsible for the loss of renal function over time. ${ }^{1,2}$ The severity of proteinuria correlates with that of tubuloinierstitial injury and the rate of declining renal function in both experimental and human proteinuric renal diseases, ${ }^{2-7}$ and evidence in rat models shows that angiotensin-converting enzyme (ACE) inhibitors prevent proteinuria and ameliorate renal structural and functional injury. ${ }^{8-14}$

From the Marin Negri Instilute for Pharmacological Reseurch; and the Division of Nephrology and Dialysis. Azienda Ospedaliera, Ospedali Riuniti di Bergamo, Bergamo. Italy.

Received Felruary 14, 2000; accepted in revised form July 14, $201 \%$.

Presented in part at the 3/st Annual Meeting of the American Society of Nejhrologr. Philadelphia. PA. October 25-28, 1998.

Address reprim requests to Carla Zoja, BiolSciD, Mario Negri Institute for Pharmacological Research. Via Giva: zeni II. 24I25 Bergamo, Italy: E-mail: zoju(a)irfinn.mnegri.it

c. 2010 by the National Kidney Forndation. Inc.

$0272-6386 /(10 / 3606-001753.00 / 0$

doi:10.105.3/ajkel.2000.19838
Studies have convincingly documented that excessive filtration and tubular reabsorption of proteins as a consequence of increased glomerular permeability lead to the activation of tubulardependent pathways of interstitial inflammation. Thus, in rats with Adriamycin (Pharnacia and Upjohn, Milan, Italy) nephrosis ${ }^{\text {is }}$ or age-related proteinuria, ${ }^{3}$ accumulation of filtered proteins in the cytoplasm of proximal tubular cells was consistently followed by an interstitial inflammatory reaction. Similarly, in rats administered repeated injections of albumin, excessive amounts of albumin in the tubular filtrate may act to promote macrophage and T-lymphocyte infiltration into renal interstitium and subsequent accumulation of extracellular matrix components. ${ }^{16} \mathrm{~A}$ number of proinflammatory molecules are believed to be responsible for cell recruitment, including such chemokines as monocyte chemoattractant protein-1 (MCP-1), regulated upon activation normal $T$-cell expressed and secreted (RANTES), and osteopontin, which are upregulated in vivo by protein overload of proximal tubular cells. ${ }^{17-19}$ The phenotypic character of proximal tubular cells changes in vitro in response to protein overloading in such a way that 
genes encoding vasoactive and inflammatory substances are upregulated. Thus, exposure to albumin, immunoglobulin $G(\operatorname{IgG})$, or transferrin caused concentration-dependent increases in the rate of synthesis of endothelin-1.20 Similarly, high concentrations of proteins stimulated the transcription of the genes for MCP-1 ${ }^{21}$ and RANTES,22 chemokines that share potent chemotactic properties for monocytes/macrophages and $T$ lymphocytes. Enhanced secretion of endothelin-1 and chemokines was mainly polarized toward the basolateral compartment of the cultured cells. ${ }^{20-22}$ The same events occurring to the same extent in vivo would mean that excessive amounts of proinflainmatory substances generated in response to protein overload can accumulate in the renal interstitiun to initiate local inflammation.

Like many other proinflammatory genes, activation of the MCP-1 and RANTES genes is controlled by the transcription factor, nuclear factor kappa B (NF-kB), ${ }^{23,24} \mathrm{NF}-\mathrm{kB}$ is composed of homodimeric or heterodimeric complexes of the Rel/NF-kB family of proteins, designated $\mathrm{p} 50, \mathrm{p} 52, \mathrm{p} 65, \mathrm{c}-\mathrm{Rel}$, and RelB, ${ }^{25.26} \mathrm{NF}-\mathrm{kB}$ dimers are present in the cytosol of unstimulated cells in an inactive form bound to the inhibitory protein, $\mathrm{lkB} .{ }^{27}$ Cell activation by such triggers as cytokines, viruses, and oxidants leads to proteolytic degradation of $\mathrm{IkB}$, allowing NF-kB translocation into the nucleus for binding to DNA motifs in gene promoters. ${ }^{25}$

We recently found that in cultured proximal tubular cells, albumin overloading activated $\mathrm{NF}-\mathrm{kB}$ in a dose-dependent manner; this correlated with increased production of RANTES. ${ }^{22}$ That this transcriptional pathway is responsible for protein-induced chemokine production is supported by the finding that inhibitors of NF-kB activation fully prevented the formation of RANTES $^{22}$ and reduced MCP- 1 upregulation ${ }^{28}$ in this setting.

In the present study, we sought to (1) assess NF-kB activation and $\mathrm{MCP}-1$ messenger RNA (mRNA) expression over time in two models of progressive proteinuric nephropathy ( $5 / 6$ nephrectomy and passive Heymann nephritis [PHN]), and (2) evaluate the effects of reducing protein traffic by means of an ACE inhibitor on NF-kB activation, MCP- 1 expression, and the extent of interstitial accumulation of mononuclear cells.

\section{METHODS}

\section{Experimental Design}

Male Sprague-Dawley rats (Charies River Italia spa, Calco, Italy) with initial body weights of 275 to $320 \mathrm{~g}$ were used in these studies. Animal care and treatment were conducted in conformity with institutional gridelines, which comply with national (Decreto Legislativo [DL] no. 116, Gazzetta Uffciale [GU], supp] 40, 18 February 1992, Circolare no. 8, GU, 14 Luglio 1994) and intemational laws and policies (Economic European Comununity [EEC] Council Directive 86/ 609, Official Joumal L [OJL] 358, December 1987; National Institutes of Health Guide for the Care and Use of Laboratory Animals, US National Research Council, 1996). AL animals were housed in a constant-temperature room with a 12-hour-dark 12-hour-light cycle and fed a standard diet. Renal mass reduction (RMR) was obtained by right nephrectomy and ligation of two or three branches of the left renat artery. ${ }^{29}$ Four groups of rats ( $n=8$ in each gromp) were killed $7,30,60$, and 90 days after surgery. Sham-operated rats killed day 60 were used as controls. To assess the effects of an ACE inhibitor, two additional groups of rats with RMR were administered lisinopril (Merck Sharp \& Dohme, Rome, Italy), $2 \mathrm{mg} / \mathrm{d}$, in the drinking water ${ }^{\text {To }}$ from day 7 after surgery until day 60 or 90 (b $=8$ in each group); then the animals were killed.

PHN was induced in nonanesthetized rats by a single intravenous injection of $0.4 \mathrm{~mL} / 100 \mathrm{~g}$ of body weight of rabbit anti-FxIA antibody. Seven days later. when proteinuria was present, animals underwent tnilateral nephrectomy to accelerate the onset of renal damage." PHN rats were killed day 7 or month $1,2,4$, or 8 after disease induction ( $n=4$ each tirne, except for month $8, n=5$ ); five rats were treated with lisinopril, $2 \mathrm{mg} / \mathrm{d}$, in the drinking water ${ }^{12}$ from day 7 after PHN induction for 8 months. Age-matched groups of normal rats ( $n=4$ in each group) were used as controls for each time point. In an additional experiment, a group of five rats with PHN at an advanced phase of the disease, ie, 4 months, wore administered a high dose of lisinopril $(20 \mathrm{mg} / \mathrm{d}\}$ in the drinking water until month 8; five untreated PHN rats and four normal rats wete studied for the same period.

Twenty-four-hour urine samples were collected in metabolic cages before disease induction and at cach subsequent time point to determine urinary protein excretion. Proteinuria was determined by the modified Coomassie blue $G$ dyc-binding assay for proteins, with bovine serum albumin (BSA) as the standard. ${ }^{32}$ Systolic blood pressure was recorded by tail plethysmography in conscious rats with RMR at 0,60 , and 90 days and rats with PHN at 0,4 , and 8 months.

The rats wer anestherized and killed, and the kidneys were removed and further processed to determine NF-kB activity and MCP-1 mRNA expression by Northem blot analysis, in situ bybridization, and immunohistochemistry. ACE activity was measured in the renal tissuc of 8-month PHN rats untreated or treated with high-dose ACE inhibitor and in the comesponding controls. 


\section{Preparation of Nuclear Extracts}

Nuclear extracts from whole-kidney tissue were prepared using a modified method of Negoro et al. ${ }^{33}$ Frozen renal tissue was homogenized and resuspended in cold extraction buffer containing $20 \mathrm{mmol} / \mathrm{L}$ of $\mathrm{N}$-2-hydroxycthylpiperazinepropanesulfonic acid (HEPES)- $\mathrm{NaOH}$ (pH 7.6), 20\% glycerol, $0.35 \mathrm{~mol} / \mathrm{L}$ of $\mathrm{NaCl}, 5 \mathrm{mmol} / \mathrm{L}$. of $\mathrm{MgCl}_{2}, 0.1 \mathrm{mmol} / \mathrm{L}$. of EDTA, $1 \mathrm{mmol} / \mathrm{L}$ of ctithiothreitol (DTT), $0.5 \mathrm{mmol} / \mathrm{L}$ of Pefabloc (Boehringer Mannheim, Mannheim, Germany), 1 $\mu \mathrm{g} / \mathrm{mL}$ of pepstatin $A$, and $2 \mu \mathrm{g} / \mathrm{mL}$ of aprotinin. The homogenate was shaken and rocked at $4^{\circ} \mathrm{C}$ for 30 minutes, and insoluble materials were precipitaled by centrifugation at $40,000 \mathrm{~g}$ for 30 minutes at $4^{\circ} \mathrm{C}$. The supernatant was dialyzed overnight against a buffer containing $20 \mathrm{mmol} / \mathrm{L}$ of HEPES-NaOH (pH 7.6), 20\% glycerol, 0.1 moll $\mathrm{L}$ of $\mathrm{NaCl}, 5$ $\mathrm{mmol} / \mathrm{L}$ of $\mathrm{MgCl}_{2}$, and $0.1 \mathrm{mmol} / \mathrm{L}$ of EDTA. The dialyzed supernatant was cleared by centrifugation at $10,000 \mathrm{~g}$ for 15 minutes at $4^{\circ} \mathrm{C}$. The supernatant collected (nuclear extract) was divided into aliquots and stored at $-70^{\circ} \mathrm{C}$ for subsequent use. Protein concentrations were determined by the Bradford assay using the Biorad (Richmond, $C A$ ) protcin assay teagent.

\section{Electrophoretic Mobility Shift Analysis}

The kB DNA sequence of the immunoglobulin gene was used for the electrophoretic mobility shift analysis (EMSA: S'CCGGTCAGAGGGGACTTRCCGAGACT). The core kB sequence is undertined. Probe DNA (with $5^{\prime}$ overhangs) was cnd-labeled by the kleenow enzyme with $\alpha-{ }^{32}$ P deroxycytidine triphosphate (dCTP) and separated from unincorporated nucleotides over a G-50 Sephadex column (Amersham Plarmacia Biotech, Uppsala. Sweden). Nuclear extracts (20 $\mu \mathrm{g})$ were equilibrated for 10 minutes at room temperature in a binding buffer containing $4 \%$ glycerol, $1 \mathrm{mmol} / \mathrm{L}$ of $\mathrm{MgCl}_{2}, 0.5 \mathrm{mmol} / \mathrm{L}$ of EDTA, $0.5 \mathrm{mmol} / \mathrm{L}$ of DTT, 50 $\mathrm{mmol} / \mathrm{L}$ of $\mathrm{NaCl}, 10 \mathrm{mmol} / \mathrm{L}$ of Tris- $\mathrm{HCl}(\mathrm{pH} 7.5$ ), and 50 $\mu \mathrm{g} / \mathrm{mL}$ of poly $(\mathrm{dl}-\mathrm{dC}$ ). Labeled $\mathrm{NF}-\mathrm{kB}$ oligonucleotide $(50$ $10^{3}$ count per minute) was added to the binuing reaction mixture and incubated for 20 minutes at room temperature. The DNA-protein conplexes were electrophoresed on a nondenaturing $5 \%$ polyacrylamide gel at $120 \mathrm{~V}$ for approximately 3 bours to maximize the separation of proteins and achieve some degree of resolution between the migration of different homodimer and heterodimer complexes that could bind to the labcled oligonucleotide. Consequently, the free probe migrated off the gel and was not present on the autoradiograph replicas. The gel then was dried and subjected to autoratiography.

To assay the specificity of the binding reaction, a 100 -fold excess of unlabcled NF-kB probe or an unlabeled nonspecific oligonucleotide (tissue plasminogen activator [TPA] regulatory element [TRE]) ${ }^{\text {is }}$ was added to the binding reaction mixture 10 minutes before the addition of the labeled probe. For densitometric analysis, an equal-sized box was drawn around each band. and the volume density was determined in arbitrary units. The sum of the volume density of bands for a single sanple was used as an indirect measure of NF-kB activation and cxpressed as a fold increage of the mean NF $\mathrm{kB}$ densitometry of control animals.

For antibody EMSA, the reaction mixture minus the probe was incubated for 1 hour at room temperature with concentrated rabbit antisera specific for p65 (sc-109), p50 (sc-1 14), c-Rel (sc-71), RelB (sc-226), or p52 (sc-298; Santa Cruz Biotechnology, Santa Cruz, CA). The labeled NF-kB oligonucleotide was then added, and incubation was contisued at room temperature for 20 minutes. The optimal antibody concentrations ( $1 \mu \mathrm{g}$ for $\mathrm{p} 50 ; 2 \mu \mathrm{g}$ for $\mathrm{p} 65$, c-Rel, RelB, and p52) and incubation period necessary to supershiff or reduce the intensity of the complexes were determined in prelimituary experiments.

\section{Northern Blot Analysis}

Total RNA was isolated trom whole-kidncy tissue by the guanidium isothiocyanate/cesium chloride procedure, as previously described. ${ }^{35}$ Twenty micrograms of total RNA was then fractionated on $1.6 \%$ agarose gel and blotted onto synthetic membranes (Zeta-probe; Biorad). Plasmid containing murine JE/MCP-1 probe was provided by Dr Charles $D$. Stiles (Harvard Medical School and Dana-Faber Cancer Institute, Boston, MA). MCP-1 mRNA was detected by using 577 bp of an MCP-l complementary DNA (cDNA). . $^{3 \text { h }}$ The cDNA fragment of MCP-1 was labeled with $\alpha-32 \mathrm{P}$ dCTP by randum-primed method. Hybridization was performed overnight in $0.5 \mathrm{~mol} / \mathrm{L}$ of $\mathrm{Na}_{2} \mathrm{HPO}_{4}(\mathrm{pH} 7.2)$ and $7 \%$ soditm dodecyl sulfate (SDS). Filters were washed twice for 30 minutes with 40 mmoll of $\mathrm{Na}_{2} \mathrm{HPO}_{4}$ (pH 7.2) and $5 \%$ SDS and twice for 10 minules with $40 \mathrm{mmol} / \mathrm{L}$ of $\mathrm{Na}_{2} \mathrm{HPO}_{4} \mathrm{(pH}$ $7.2)$ and $1 \%$ SDS at $65^{\circ} \mathrm{C}$. Mcmbranes were subsequently probed with a glyceraldehyde-3-phosptiale dehydrogenase (GAPDH) CDNA, taken as the internal standard of equal losding of the samples on the membrane. MCP-1 mRNA optical density was nomalized to that of the constituently released GAPDH gene expression.

\section{In Situ Hybridization}

The murine MCP-1 antisense and sense RNA probes were prepared and labeled by in vitro transcription using digoxigenin-jabeled uridine triphosphate (Boehringer Mannheim Biochemica, Mannheim, Germany). ${ }^{37}$ A 577-bp murine MCP-1 cDNA was cloned into the EcoRI site of the PGEM-1 vector between SP6 and T7 promoters. Fragments of renat cortex were fixed in Dubosq-Brazil, dehydrated in alcohol, and embedded in paraffin. Sections were cut at $4 \mu \mathrm{m}$ and processed as previously described. ${ }^{37}$ Brietly, after penneabilization with proteinase $\mathrm{K}(40 \mu \mathrm{g} / \mathrm{mL}$; Sigma, St Louis, MO), the sections were hybridized with the RNA probes at the final concentrations of 0.1 to $0.5 \mathrm{ng} / \mathrm{\mu L}$ in $2 \times$ sodium chloride/sodium citrate (SSC), $10 \%$ dextran sulfate, $1 \times$ Denhardt's solution, $20 \mathrm{mmol} / \mathrm{L}$ of Vanadyl Ribontelcoside Complex (Gibco BRL, Life Technologies, Gaithersburg. MD), and $0.1 \mathrm{~mol} / \mathrm{L}$ of sodium phosphate and incubated overnight in a moist chamber at $45^{\circ} \mathrm{C}$. After being washed in $0.2 \times$ SSC and blocked with a buffer-blocking solution ( 50 $\mathrm{mg} / \mathrm{mL}$ of skimmed dried milk, $150 \mathrm{mmol} / \mathrm{L}$ of $\mathrm{NaCl}$ in 100 $\mathrm{mmol} / \mathrm{L}$ of Tris HCL, pH 7.8) at room tempernture for 30 
minutes, the sections were incubated with antidigoxigenin antibody conjugated with alkaline phosphatase (Boehringer Mannheim Biochemica) at a dilution of 1:1,000 for 45 minutes at $37^{\circ} \mathrm{C}$. Colorimetric detection with nitro blue tetrazolium salt and 5-bromo-4-chloro-3-indolyl phosphate (Boehringer Mannheim Biochemica) was then performed, and the sections were mounted in $60 \%$ glycerol and examined by light microscopy. The negative control included hybridization step with the sense probe.

\section{Immunohistochemical Analysis}

The $\mathrm{p} 50$ subunit of NF-kB was localized as described by Morrissey and Klahr ${ }^{38}$ in kidneys from rats with RMR or sham operation at day $60(n=3)$. The kidneys were perfused with ice-cold Hank's balanced salt solution, followed by Histochoice (Amresco, Solon, OH). Four-micron sections of paraffin-embedded kidneys were deparaffinized, rehydrated, and treated with $3 \%$ hydrogen peroxide methanol $(1: 3)$ for 20 minutes. They were blocked in $5 \%$ goat serum and incubated with $20 \mu \mathrm{g} / \mathrm{mL}$ of polyclonal rabbit anti-p50 antibody (Sants Cruz Biotechnology), diluted in $1 \% \mathrm{BSA} /$ phosphate-buffered saline (PBS) at $4^{\circ} \mathrm{C}$ overnight. The sections were washed in PBS and incubated with biotin-conjugated goat antirabbit IgG (Vector Laboratories. Burlingame, $C A$ ) for 1 hour. After washing, they were incubated with avidin biotin complex (ABC) reagent (Vector Laboratories) for 30 minutes and washed again. Diaminobenzidine (DAB)- $\mathrm{H}_{2} \mathrm{O}_{2}$ solution (Merck, Darmstadt, Germany) was applied to reveal binding sites. The sections were washed, dehydrated, and mounted using a nonaqueous mounted medium.

Mouse inonoclonal antibodies were used for the detection of ED-1 antigen expressed in rat monocytes and macrophages (Chemicon, Temecula, CA) and rat CD8 cell-surface glycoprotein on T-suppressor cells (OX8; Chemicon). ED-1 antigen was stained on paraffin sections using an alkaline phosphatase-Fast Red technique (Boehringer Mannheim), as described. ${ }^{34} \mathrm{CD} 8$ staining was performed by indirect imnunofltorescence technique. Fragments of renal tissues were frozen in liquid nitrogen and cut at $5 \mu \mathrm{m}$ using a Mikrom $500 \mathrm{O}$ cryostat (Walldorf, Germany). The sections were blocked with $1 \%$ PBS/BSA, incubated overnight at $4^{\circ} \mathrm{C}$ with primary antibody $(1: 100)$, washed with PBS, and then incubated with Cy3-conjugated donkey antimouse IgG antibodies $(5 \mu \mathrm{g} / \mathrm{mL}$ in PBS; Jackson ImmunoResearch Laboratories, West Grove, PA) for 1 hour at room temperature. For each marker, positive cells were counted in at least 10 randomly selected high-power fields (original magnification $\times 400$ ) per cach animal.

\section{Measurement of ACE Activity}

Whole-kidney tissuc was homogenized in distilled water and centrifuged at $12,000 \mathrm{~g}$ for 10 minutes at $4^{\circ} \mathrm{C}$. The resulting supernatant was used for $A C E$ activity determination by a spectrophotometric method (Sigma), described by Ruiz-Ortega et al. ${ }^{14}$ ACE activity was expressed as relative units per milligram of tissue protein.

\section{Statistical Analysis}

Results are expressed as mean $\pm S E$. Data were analyzed using the nonparametric Kruskal-Wallis test for multiple

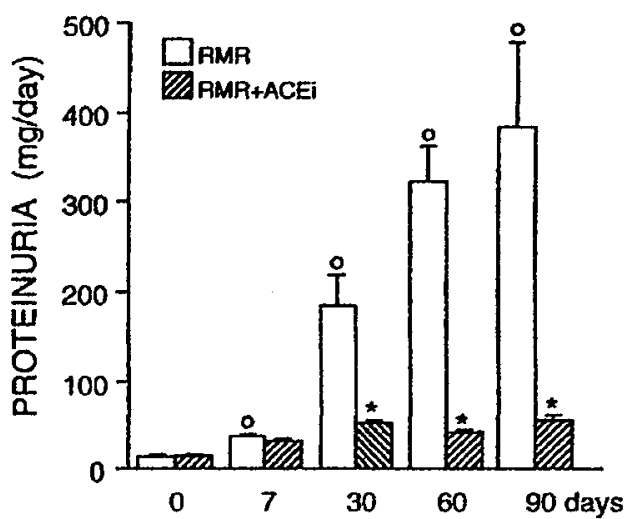

Fig 1. Time course of urinary protein excretion in rats with RMR and effect of the ACE inhibitor (ACE), lisinopril, administered from day 7 after surgery until day 60 or 90 . Results expressed as mean $\pm S E$. ${ }^{\circ} P<$ 0.01 versus day 0 (basal). " $P<0.01$, RMR rats treated with lisinopril versus untreated RMR rats at corresponding days.

comparisons. Statistical significance level is defined as $P$ less than 0.05 .

\section{RESULTS}

\section{Activation of NF-kB in the Remnant Kidney and Effect of Antiproteinuric Drug Therapy}

Rats with RMR had high levels of urinary protein excretion starting day 7 after surgery (Fig 1). Administration of lisinopril from day 7 significantly reduced proteinuria at subsequent time points until day 90 . Lisinopril inhibited the progressive increase in systolic blood pressure occurring in rats with remnant kidneys (lisinopriltreated versus untreated rats at day $60,134 \pm 7$ versus $176 \pm 8 \mathrm{~mm} \mathrm{Hg}$; day $90,131 \pm 7$ versus $180 \pm 5 \mathrm{~mm} \mathrm{Hg} ; P<0.05$ ). The increase in urinary protein excretion over time was paralleled by increased NF-kB activation, determined in nuclear extracts from renal tissue using EMSA and radiolabeled NF-kB oligonucleotide.

The kinetic analysis of NF-kB DNA-binding activity is shown in Fig 2. Nuclear extracts from the sham-operated control rats showed a single lower band designated complex I. Beginning day 7 in remnant kidneys, a gradual increase in the upper area of complex I was observed, along with the appearance of two other complexes, 

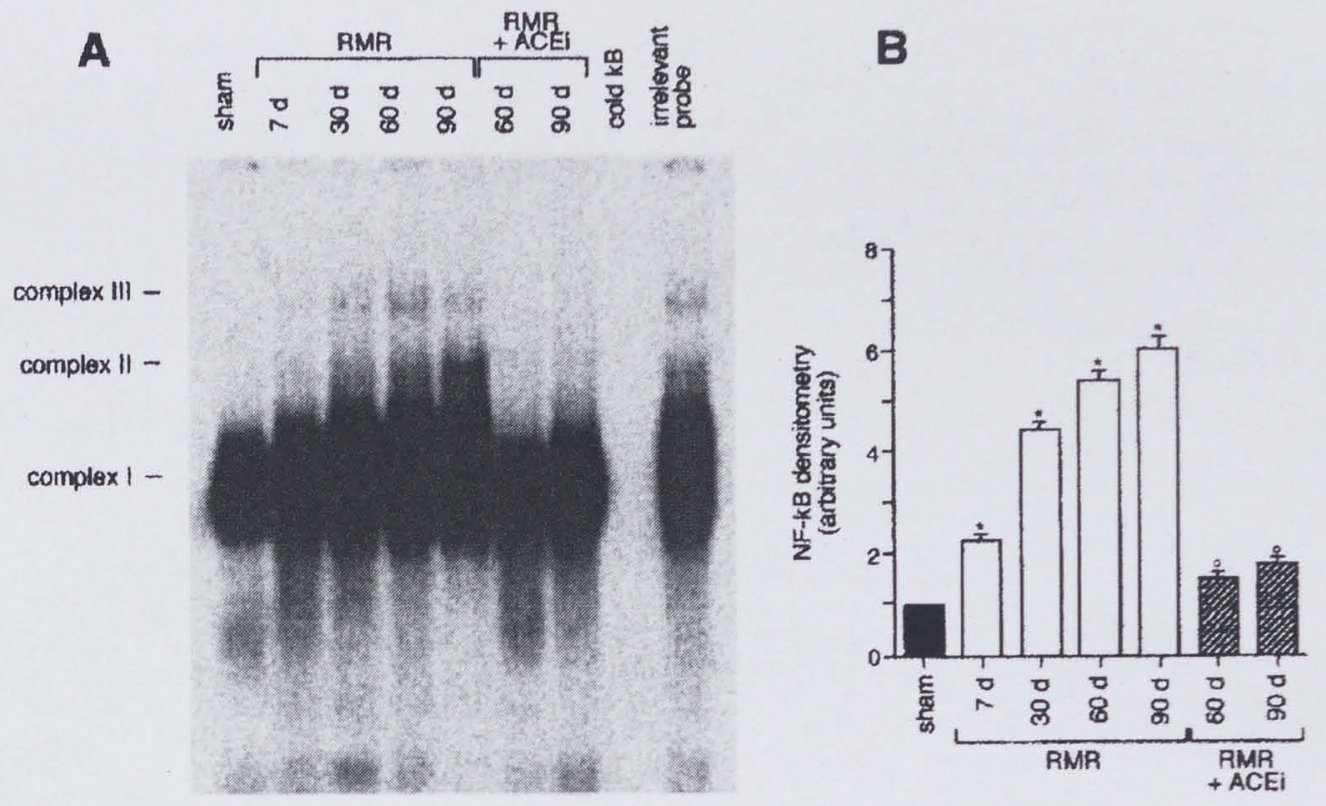

Flg 2. (A) EMSA for NF-kB in nuclear extracts from whole-kidney tissue of sham-operated rats and rats with RMR at different times from surgery and effect of lisinopril. Experiments were performed using nuclear extracts of elther separate ( $n=4$ rats for each group) or pooled samples incubated with a consensus NF-kB ollgonucleotide labeled with ${ }^{32}$ P. Results shown are representative of pooled samples for each group. A 100-fold molar excess of uniabeled NF-kB (cold) or an unlabeled nonspecific oligonucleotide (irrelevant probe) was added to nuclear extract from day 60 of RMR. (B) Densitometric analysis of autoradlographic signals of NF-kB activity. An equal-sized box was drawn around each band, and volume density was determined in arbitrary units (see Methods). The density of complex I was determined by performing densltometry on autoradlograph replicas of shorter exposure. Results are shown as mean \pm SE of four separate animals for each group and expressed as fold increase over sham (represented as 1) in densitometric arbitrary units. ${ }^{*} \boldsymbol{P}<0.05$, RMR versus sham-operated rats, ${ }^{\circ} \boldsymbol{P}<0.05$, RMR lisinoprll-treated versus untreated RMR rats days 60 and 90 . Abbreviation: ACEl, ACE inhibitor.

faster and slower migrating bands termed complexes II and III, respectively. By densitometric analysis, a twofold increase in NF-kB activity was observed in remnant kidneys at day 7 . Maximal activation occurred between days 60 and 90 (5.4- to 6-fold more than sham). Lisinopril almost completely suppressed the time-dependent increase in NF-kB activity in remnant kidneys measured at either day 60 or day 90 . The addition of a 100-fold excess unlabeled NF-kB oligonucleotide (cold $\mathrm{kB}$ ) to nuclear extracts of day- 60 remnant kidneys resulted in the disappearance of the bands on autoradiographs, thus confirming specificity of the NF-kB binding reaction. Conversely, signal intensity was not affected by incubation with an irrelevant oligonucleotide (TRE).

Gel supershift analysis was used to determine the subunit specificity of the activated NF- $k B$ complexes in remnant kidney (Fig $3 \mathrm{~A}$ ). Complex I predominantly consisted of $\mathrm{p} 50 / \mathrm{p} 65$ heterodimers and $\mathrm{p} 50 / \mathrm{p} 50$ homodimers because incubation of extracts from day-60 remnant kidneys with either anti-p65 or anti-p50 antibodies resulted in a slight depletion of the complex and the formation of supershifted bands. With the anti-p50 antibody, a greater intensity supershifted band migrating in close proximity to complex III was observed. Antisera to RelB and p52 had no effect on the density of complex I. Anti-cRel antibody caused a very slight decrease in the intensity of complex I, which suggests a possible involvement of cRel subunit in the composition of this complex. Complex II contained cRel dimers because anti-cRel antibody partially reduced the signal intensity. At variance, com- 


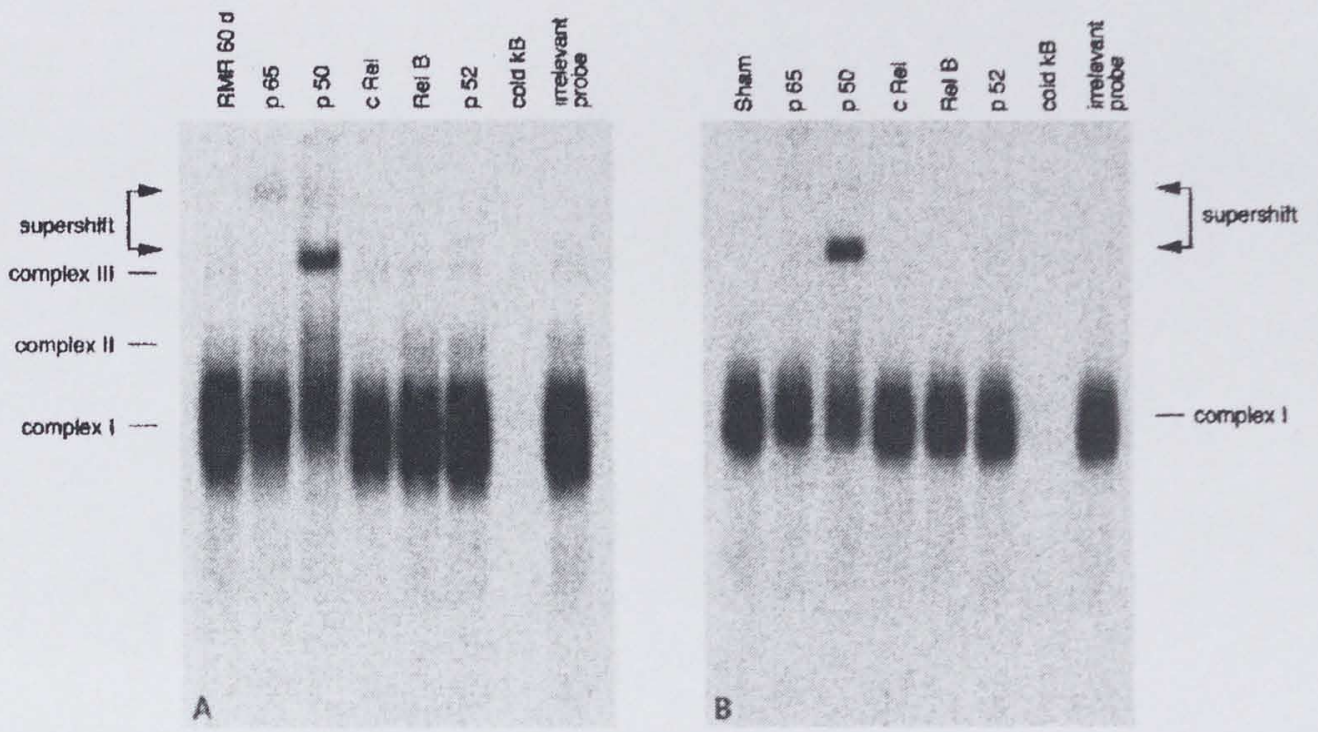

Fig 3. Subunit composition of activated NF-kB in (A) rats with RMR at day 60 and (B) sham-operated control rats. Nuclear extracts from whole-kidney tissue were incubated with antibodies against p65, p50, c-Rel, RelB, and p52. Antibody supershifts produced by binding of the antibody to the NF-kB-Rel protein complex are Indicated. Results shown are representative of three independent experiments using different nuclear extracts.

plex III was not recognized by any of the antisera, and its identity remains to be determined. The subunit pattern of complex $I$ in remnant kidneys from rats treated with lisinopril was the same as in untreated rats (not shown). In shamoperated rats (Fig 3B), constitutional expression of complex $J$ consisted of dimers containing p 50 and p65 subunits because only the respective antisera partially reduced the density of this band and caused the formation of supershifted bands. Antisera to cRel, RelB, and p55 had no effect on the density of complex I.

To identify structures in which NF-kB could be activated, we performed immunocytochemical analysis using an antibody to the p 50 subunit. In kidneys of sham-operated rats, weak staining was found in tubular epithelial cells of proximal and distal profiles (Fig 4A). In remnant kidneys, a strong nuclear reactivity was visualized in proximal tubular epithelial cells and in sparse cells in the renal interstitium (Fig 4B). Some glomeruli in remnant kidney also showed p50 staining, with apparent distribution to glomerular epithelial areas (Fig 4C).

\section{Effect of Lisinopril on MCP-1 mRNA Expression in the Remnant Kidney}

The time course of renal MCP-1 gene expression in rats with RMR, monitored by Northern blot analysis, is shown in Fig 5. A single $0.7-\mathrm{kb}$ MCP-1 mRNA transcript of low intensity was detected in the kidneys of sham-operated control rats. In rats with remnant kidneys, message levels increased markedly with time, concomitant to NF-kB activation (Fig 2). Thus, as shown by densitometric analyses of the autoradiographic signals, renal MCP-1 mRNA levels at days 7, 30, 60 , and 90 were 1.9-, 4.4-, 6.8-, and 5.3-fold greater than those of controls, respectively. MCP-I gene upregulation was inhibited by $70 \%$ and $74 \%$ at days 60 and 90 by lisinopril, respectively (Fig 5).

By in situ hybridization using antisense $\mathrm{MCP}-1$ RNA probe, kidneys from sham-operated rats had very weak or no signal (Fig 6a). Conversely, a strong perinuclear and cytoplasmic signal was visualized mainly in tubular epithelial cells in the 60 -day remnant kidneys (Fig 6b). Based on morphological characteristics and the relatively high 

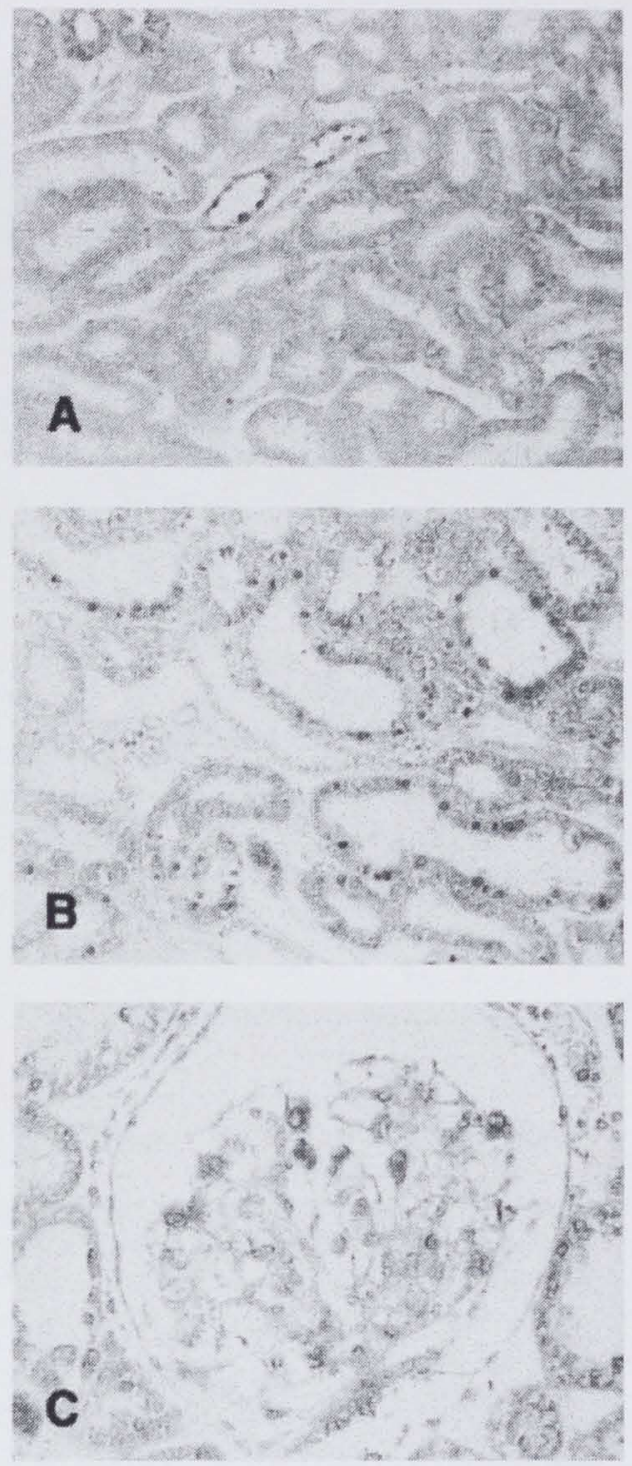

Fig 4. Detection of p50 subunit of NF-kB in tissue sections of kidney cortex. In contrast to (A) a shamoperated rat kidney showing weak and occasional nuclear staining in some tubules, (B) strong NF-kB nuclear staining is seen in areas of 60-day remnant kidney, mainly localized to proximal tubular cells. (C) Glomerular proflle micrograph showing p50 reactivity, which appears to be mainly associated with glomerular epithelial cells. (Original magnification: A, B ×170; C $\times 340$.)

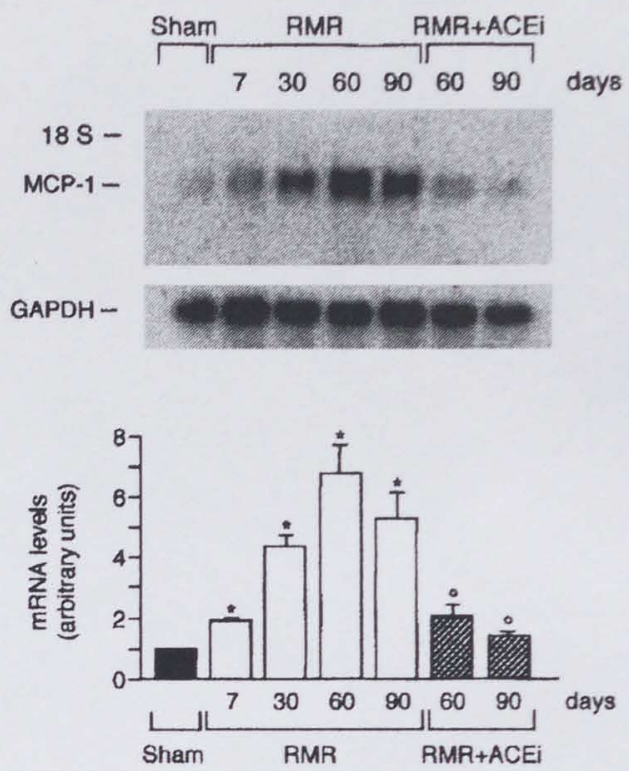

Fig 5. (Top) Time-dependent renal expression of MCP-1 mRNA in rats with RMR and effect of lisinopril. Northern blot experiments were performed using total RNA from whole-kidney tissue of either separate ( $n=$ 4 rats for each group) or pooled samples. Results shown are representative of pooled samples for each group. (Bottom) Densitometric analysis of the autoradiographic signals for MCP-1. Results shown as mean \pm SE of four separate animals for each group. The optical density of the autoradiographic signals was quantitated and calculated as the ratio of MCP-1 to GAPDH mRNA. Results expressed as fold increase over sham (represented as 1) in densitometric arbitrary units. ${ }^{*} P<0.05$, RMR versus sham-operated rats. ${ }^{\circ} \boldsymbol{P}<0.05$, RMR lisinopril-treated versus untreated $R M R$ rats days 60 and 90 . Abbreviation: $A C E I, A C E$ inhibitor.

proportion of positive tubules in the cortex, MCP-1 staining was identified in the profiles of proximal tubules. Positive MCP-1 mRNA staining was also present in interstitial cells and resident glomerular cells, particularly some parietal cells of Bowman's capsule and scattered podocytes. Conversely, the signal remained low in the remnant kidneys of rats treated with lisinopril (Fig 6c). No staining was detected in remnant kidney sections incubated with the corresponding sense MCP-1 probe (Fig 6d).

Effect of Lisinopril on Interstitial Mononuclear Cell Infiltration in the Remnant Kidney

Compared with sham-operated rats, increasing numbers of ED-1-positive monocytes/macro- 

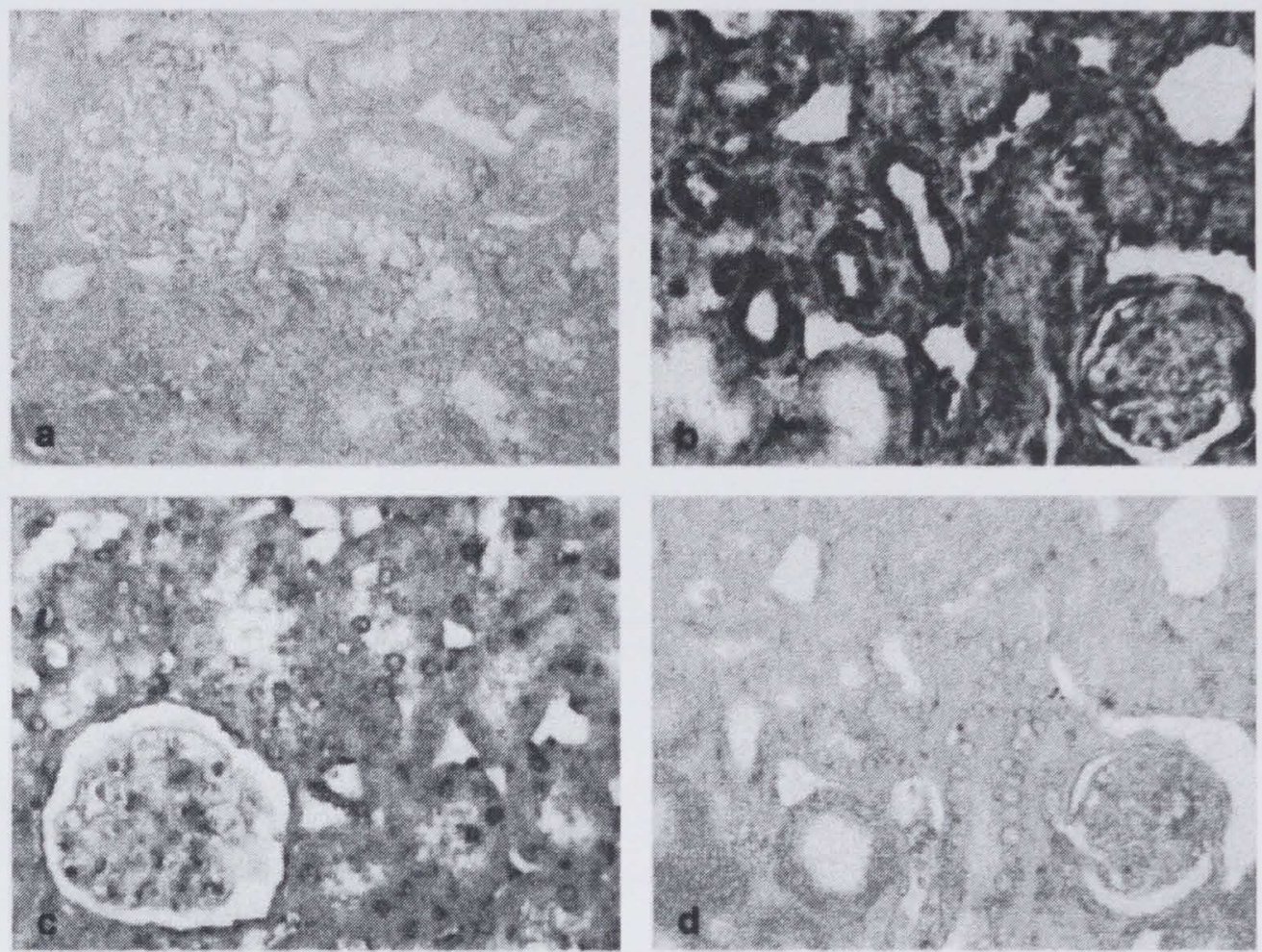

Fig 6. Photomicrographs showing MCP-1 mRNA expression by In situ hybridization in kidneys from (a) a shamoperated rat, (b) an untreated 60-day rat with RMR, and (c) a 60-day Ilsinoprit-treated rat with RMR (digoxigenin deoxyuridine triphosphate-labeled murine MCP-1 probe, alkaline phosphatase reporter system). Note the presence of strong signal in the RMR kidney, mainly in the tubular eplthellum, in contrast to sham-operated kidney and RMR rat treated with lisinopril. Positive MCP-1 mRNA staining is also detectable in some interstitial cells and glomerular epithelial celis. (d) Negative control using MCP-1 sense probe in a 60-day remnant kidney section adjacent to that shown in (b). Figure is representative of three rats examined for each group. (Original magnification $\times 180$ ).

phages were detected in the remnant kidney interstitium during disease progression, with values reaching statistical significance by day 30
(Fig 7). CD8-positive $\mathrm{T}$ cells showed the same time course (Fig 7). The degrees of infiltration of ED-1-positive cells and CD8-positive $T$ cells
ED-i imonocyles/macrophoges

Fig 7. Time course of ED1-positive monocytes/macrophages and CD8-positive $T$ cells infiltrating the interstitium of rats with RMR and the effect of lisinopril. Values expressed as mean \pm SE. Abbreviation: HPF, highpower field. " $P<0.05$ versus sham and 7-day RMR rats. ${ }^{\circ} \boldsymbol{P}<0.05$ versus 60-day RMR rats.
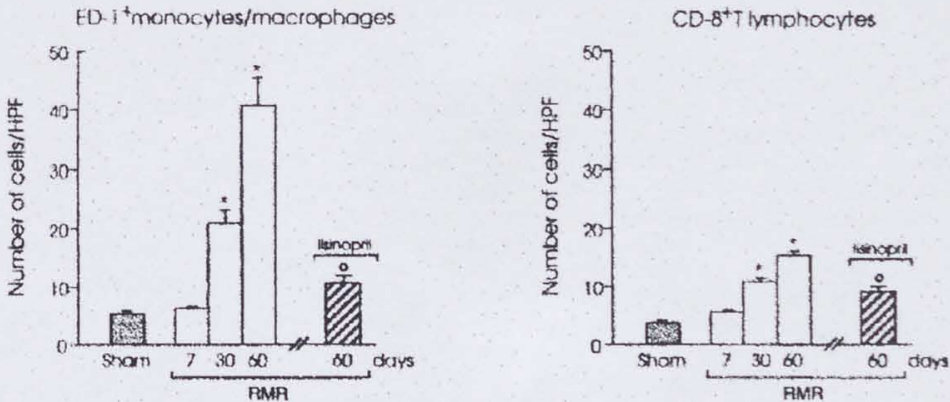

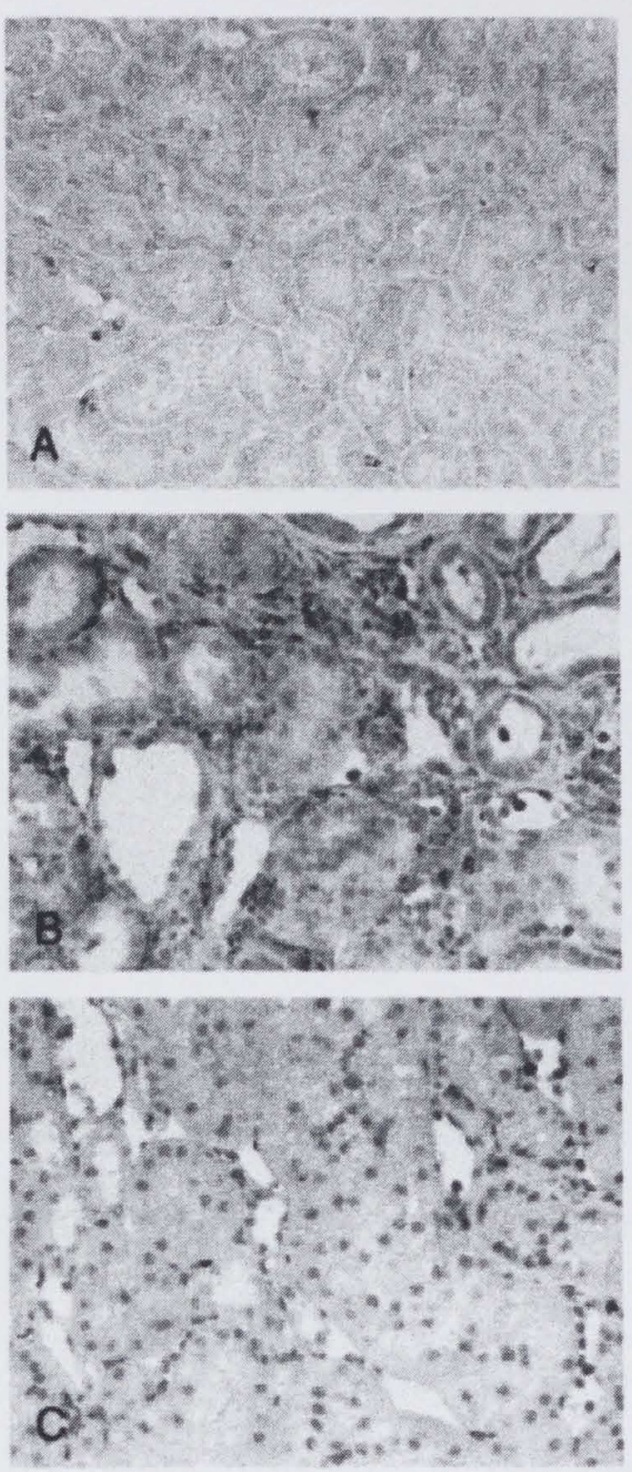

Fig 8. Photomicrographs of sections of kidney cortex obtained day 60 after surgery stained for detection of ED-1-positive monocyte/macrophages from (A) shamoperated rat, (B) untreated rat with RMR, and (C) lisinopritreated rat with RMR. The remnant kidney interstitium contains many ED-1-positive monocytes/macrophages in contrast to few ED-1-positive cells in sham-operated control interstitium. Very few ED-1-positive cells were seen in the interstitium of RMR rats treated with lisinopril compared with untreated rats with RMR. (Alkaline phosphatase-Fast Red detection, hematoxylin counterstain; original magnification $\times 180$.)

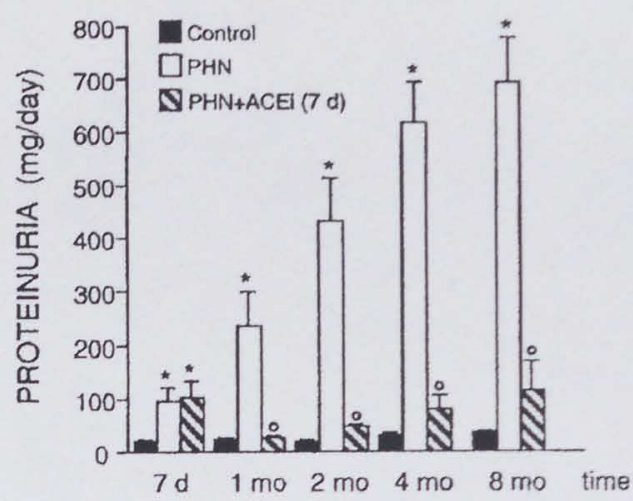

Fig 9. Time course of urinary protein excretion in PHN rats and effect of treatment with Ilsinopril from day 7 after disease induction until month 8 . Results expressed as mean \pm SE. Abbreviation: ACEI, ACE inhlbitor. ${ }^{*} P<0.05$ versus control. ${ }^{\circ} P<0.05$, lisinopriltreated PHN rats versus untreated PHN rats at corresponding time.

were markedly attenuated by treatment with the ACE inhibitor (Figs 7 and 8).

\section{Activation of NF-kB in PHN and Effect of Early Lisinopril Treatment}

Rats with PHN developed proteinuria as early as 7 days after disease induction (Fig 9). In untreated $\mathrm{PHN}$ rats, proteinuria increased during time, averaging $690 \pm 98 \mathrm{mg} / \mathrm{d}$ at month 8 . Lisinopril, $2 \mathrm{mg} / \mathrm{d}$, administered from day 7 had a marked antiproteinuric effect (urinary protein excretion, $117 \pm 66 \mathrm{mg} / \mathrm{d} ; P<0.05$ versus untreated PHN rats). Lisinopril maintained systolic blood pressure at values significantly less than those of untreated PHN rats $(114 \pm 10$ versus $158 \pm 7 \mathrm{~mm} \mathrm{Hg} ; P<0.05$ ).

As shown in Fig 10, renal NF-kB activity in PHN rats increased over time compared with control rats, beginning day 7 (2-fold) and reaching near-maximal intensity between months 4 and 8 (6- to 10 -fold). Treatment with lisinopril from day 7 resulted in normalization of NF-kB activity. The incubation of nuclear extracts from PHN rats with labeled NF-kB consensus probe produced two bands (complexes I and II). A third slower migrating band (complex III) was clearly visible in PHN rats at 8 months. Complex III was detectable as a faint band in both controls and PHN rats at earlier times only after a prolonged exposure of the autoradiograph replicas. 

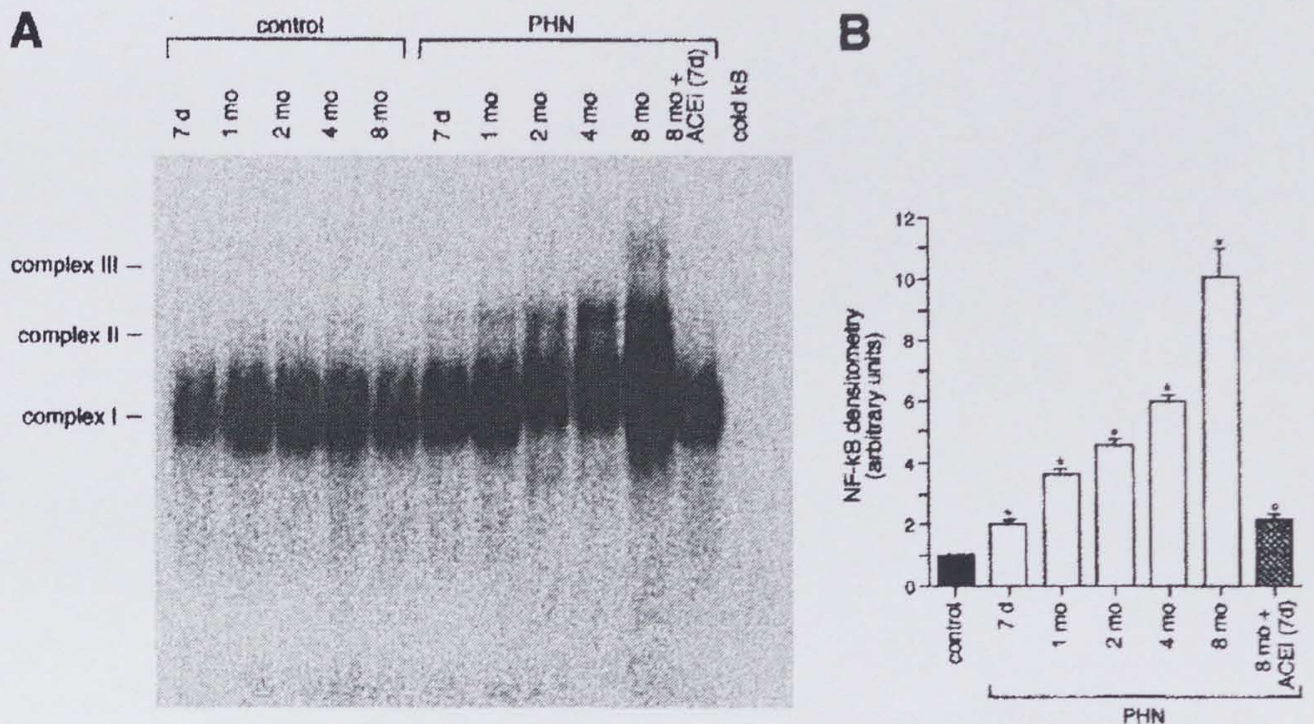

Fig 10. (A) EMSA for NF-kB in nuclear extracts from whole-kidney tissue of PHN rats and controls at different Intervals and effect of early treatment with lisinopril. Experiments were performed using nuclear extracts of either separate ( $n=4$ or 5 rats for each group) or pooled samples incubated with a consensus NF-kB oligonucleotide labeled with 32P. Results shown are representative of pooled samples for each group. A 100-fold molar excess unlabeled NF-kB (cold) was added to nuclear extract from 8-month PHN rats. (B) Densitometric analysis of autoradiographic signals of NF-kB activity. Results shown as mean \pm SE of four or five separate animais for each group and expressed as fold increase over controls of corresponding time (represented as 1) in densitometric arbitrary unlts. Abbreviation: ACEI, ACE inhibltor. ${ }^{*} P<0.05$, PHN rats versus corresponding controls. ${ }^{\circ} P<0.05$, lisinopril-treated PHN rats versus untreated PHN rats.

The specificity of the bands was determined in competition studies (Figs 10 and 11). Gel supershift assay showed that incubation of nuclear extracts of kidneys from 8-month PHN rats with either anti-p65 or anti-p50 antibodies partially reduced the intensity of complex I (Fig 11). Supershifted bands could be identified with each antibody. A greater signal intensity was observed for $\mathrm{p} 50$, which migrated faster than the $\mathrm{p} 65$ supershifted complex and in close proximity to complex III. Complex II was unaffected by p50 antisera but was partially depleted by the addition of p 65 antisera. Conversely, complex III was not recognized by antibodies to p 65 and p50 subunits. Antibodies to the other known NF-kB subunits (c-Rel, RelB, or p52) did not affect $\mathrm{NF}-\mathrm{kB}$ consensus sequence binding of complexes. The partial reduction in the density of the complexes with RelB antisera was not seen in repeated assays and was probably caused by a slight reduction in the amounts of either protein or probe that were loaded in that particular lane.
In summary, complexes I and II consisted of homodimers and heterodimers containing p65 and p50 subunits, and complex III composition remains unknown.

\section{Effect of Early Lisinopril Treatment on $M C P-I$ $m R N A$ Expression and Interstitial Mononuclear Cell Infiltration in PHN Rats}

As shown in Fig 12, renal MCP-1 mRNA expression increased during disease progression in PHN rats in parallel with the increase in NF-kB activity (day 7,2.5-fold; month 1, 4-fold; month 2, 4.5-fold; month 4, 5.5-fold; month 8, 7 -fold increase greater than corresponding controls). Treatment with lisinopril administered from day 7 determined a $74 \%$ inhibition of MCP-1 mRNA transcript levels at 8 months compared with untreated PHN rats.

A massive infiltration of ED-1-positive monocytes/macrophages and CD8-positive T cells was present in the renal interstitium of PHN rats, detected at month 8 . Early treatment with lisino- 


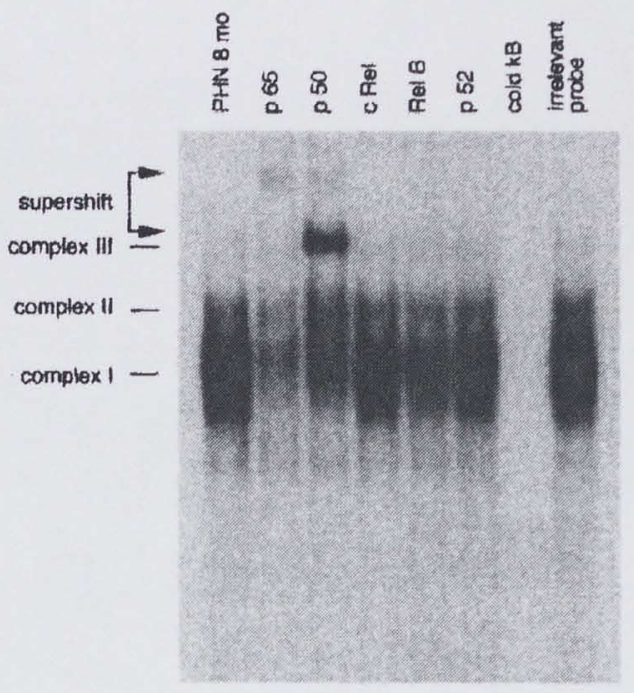

Fig 11. Subunit composition of activated NF-kB in rats with PHN. Nuclear extracts from total-kidney tissue of 8-month PHN rats were Incubated with antlbodles against p65, p50, c-Rel, ReJB, and p52. Antibody supershifts produced by binding of the antibody to the NF-kB-Rel protein complex are indicated. Results shown are representative of three Independent experiments using different nuclear extracts. To show the specificity of binding of the NF-kB oligonucleotide, a 100 -fold molar excess unlabeled NF-kB (cold) or an unlabeled nonspecific ollgonucleotide firrelevant probe) was used to compete with the labeled NF-kB probe for binding to nuclear proteins.

pril was associated with a marked reduction in inflammatory cell accumulation (Fig 13).

\section{Effect of High-Dose Lisinopril Administered in the Chronic Stage of PHN on NF-kB Activation, MCP-I mRNA Expression, and Interstitial Inflammation}

PHN rats in an advanced phase of the disease (ie, month 4) were treated for 4 months with high-dose lisinopril $(20 \mathrm{mg} / \mathrm{d})$, such that renal ACE activity was normalized (month 8 , PHN plus lisinopril, $0.76 \pm 0.06 \mathrm{U} / \mathrm{mg}$ of protein $\times$ $10^{-3}$ versus untreated PHN, $1.50 \pm 0.10 \mathrm{U} / \mathrm{mg}$ of protein $\times 10^{-3} ; P<0.05$; controls, $0.51 \pm 0.05$ U/mg of protein $\times 10^{-3} ; P<0.01$ versus untreated PHN). Systolic blood pressure values were reduced to the normal range (Table 1). Lisinopril failed to reduce proteinuria that persisted at 8 months at levels similar to those of untreated PHN rats. Renal NF-kB activity re- mained sustained and similar to that of untreated PHN animals (Fig 14). MCP-1 mRNA levels were still elevated (Fig 15), along with the massive infiltration of mononuclear cells into the renal interstitium (Fig 13).

\section{DISCUSSION}

The NF-kB family of transcription factors participates in regulating many genes with products that mediate inflammatory and immune responses. ${ }^{25}$ In kidneys from animals with proteinuric renal disease, increased expression of NF-
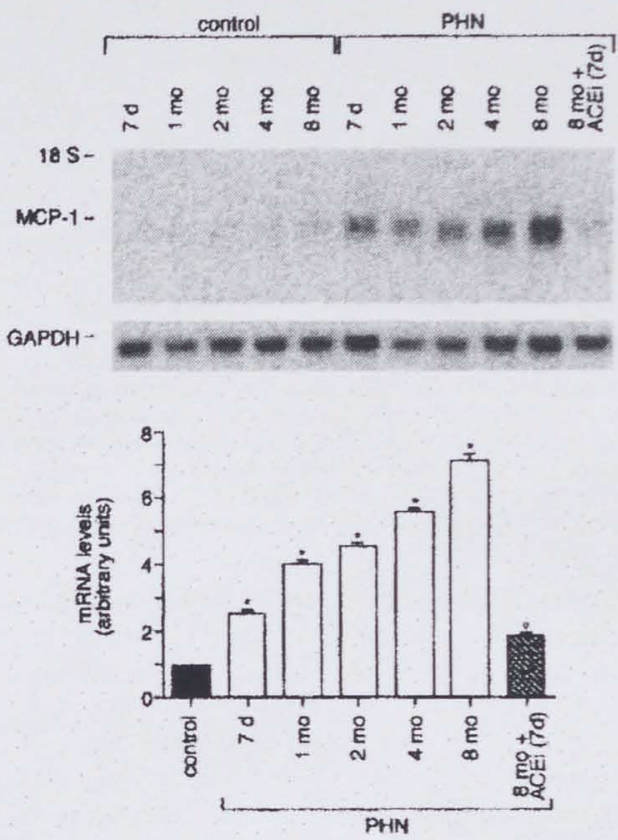

Fig 12. (Top) Time-dependent renal expression of MCP-1 MRNA in PHN rats and effect of early treatment with Ilsinoprll ( $2 \mathrm{mg} / \mathrm{d}$ from 7 days to 8 months). Northern blot experiments were performed using total RNA from whole-kidney tissue of either separate $(n=4$ or 5 rats for each group) or pooled samples. Results shown are representative of pooled samples for each group. (Bottom) Densitometric analysis of autoradiographic signais for MCP-1. Results shown as mean \pm SE of four or five separate animals for each group. The optical density of the autoradiographic signals was quantitated and calculated as the ratio of MCP-1 to GAPDH mRNA. Results expressed as fold increase over controls of corresponding time (represented as 1) in densitometric arbltrary units. Abbreviation: $A C E I$, ACE inhibitor. ${ }^{*} P<0.05$, PHN rats versus corresponding controls. ${ }^{\circ} P<0.05$, PHN lisinopril-treated rats versus untreated PHN rats. 

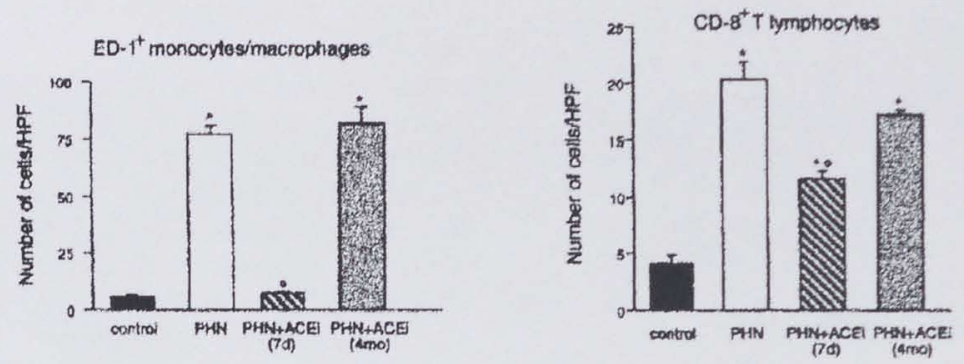

Fig 13. Accumulation of ED-1-positive (ED-1+) monocytes/macrophages and CD8-positive $\left(C D 8^{+}\right) T$ cells in the renal interstitium of PHN rats at 8 months and effect of lisinopril treatment started early (day $7 ; 2 \mathrm{mg} / \mathrm{d}$ ) or at advanced phase of disease (month 4; $20 \mathrm{mg} / \mathrm{d}$ ). Values expressed as mean \pm SE. Abbreviations: HPF, high-power field; $A C E I, A C E$ inhibltor. ${ }^{*} P<0.05$ versus control. ${ }^{\circ} P<0.05$ versus untreated $P H N$ rats.

$\mathrm{kB}$-dependent proinflammatory genes has been consistently documented. ${ }^{17,18,40,41}$ Evidence of renal NF-kB activation was also found in a variety of experimental nephropathies, including antiglomerular basement membrane nephritis, ${ }^{40}$ ureteral obstruction, ${ }^{38,42}$ and immunecomplex nephritis. $^{41}$

We first assessed renal NF-kB activity over time in models of proteinuric nephropathy initiated either by nonimmune ( $5 / 6$ renal mass ablation) or immune (PHN) insult to the kidney. In both settings, progressive increases in urinary protein excretion were accompanied by parallel increases in NF-kB DNA-binding activity. Early treatment with the ACE inhibitor, lisinopril, reduced proteinuria and effectively blocked the time-dependent increase in NF-kB activity in the kidney. This finding possibly implies that the exuberant traffic of proteins across the glomeru-

Table 1. Effect of High-Dose Lisinopril Administered at an Advance Phase of Disease on Proteinurla and SBP in Rats With PHN

\begin{tabular}{lccc}
\hline Group & $\begin{array}{c}\text { Disease } \\
\text { Phase } \\
\text { (mon) }\end{array}$ & $\begin{array}{c}\text { Proteinuria } \\
\text { (mg/d) }\end{array}$ & $\begin{array}{c}\text { SBP } \\
(\mathrm{mm} \mathrm{Hg})\end{array}$ \\
\hline PHN & 4 & $553 \pm 56$ & $143 \pm 4^{*}$ \\
PHN + lisinoprit & 8 & $655 \pm 61$ & $161 \pm 6^{*}$ \\
$(20$ mg/d) & 8 & $563 \pm 30$ & $141 \pm 2^{*}$ \\
Control & 8 & $678 \pm 13$ & $122 \pm 10 \dagger$ \\
& 4 & $38 \pm 4$ & $127 \pm 8$ \\
& 8 & $46 \pm 11$ & $134 \pm 3$ \\
\hline
\end{tabular}

NOTE. Values expressed as mean $\pm S E$. Treatment with $\mathrm{ACE}$ inhibitor started 4 months after PHN induction.

- $P<0.05$ versus control.

$+P<0.05$ versus PHN at corresponding time.
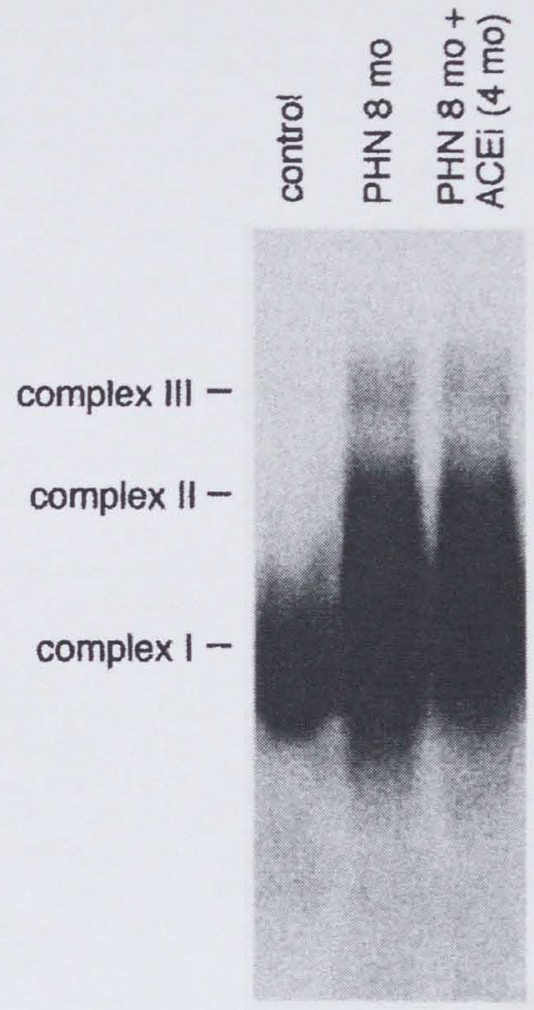

Fig 14. EMSA for NF-kB in nuclear extracts from whole-kidney tissue of PHN rats at 8 months and controls and effect of treatment with high-dose lisinopril from 4 to 8 months. Experiments were performed using nuclear extracts of either separate $(n=5$ rats for each group) or pooled samples incubated with a consensus NF-kB ollgonucleotide labeled with ${ }^{32} \mathrm{P}$. Results shown are representative of pooled samples for each group. Abbroviation: ACEI, ACE inhibitor. 

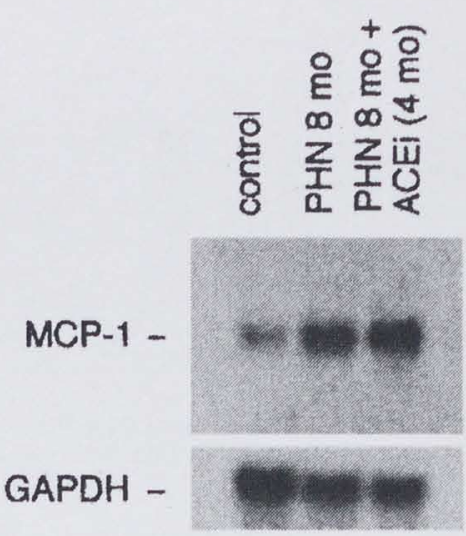

Fig 15. Effect of delayed treatment with high-dose lisinopril from 4 to 8 months on renal expression of MCP-1 mRNA. Northern blot experiments were performed using total RNA of elther separate $(n=5$ rats for each group) or pooled samples. Results shown are representative of pooled samples for each group. Abbreviation: ACEI, ACE inhibitor.

lar barrier acts as a determinant of NF-kB activation. That this transcriptional pathway can be directly activated by proteins abnormally filtered and reabsorbed in proximal tubular cells is supported by in vitro evidence that cultured proximal tubular cells exposed to high concentrations of albumin showed a dose-dependent increase in NF-kB activity with augmented RANTES ${ }^{22}$ and MCP $-1{ }^{28}$ synthesis.

Because distinct NF-kB/Rel complexes have different sequence preferences and transcriptional activation properties, ${ }^{43}$ we characterized the pattern of proteins binding to the NF-kB motif in kidney of rats with the previously mentioned forms of renal injury. EMSA-supershift experiments showed that in both the renal mass ablation and PHN models, the activated NF-kB complexes contained p50 and p65 subunits. In addition, involvement of the cRel subunit was observed for remnant kidney. The finding that the slower migrating band (complex III) in nuclear extracts from both models was unaffected by antibodies to the known NF-kB subunits leads us to speculate that this complex may contain novel $\mathrm{NF}-\mathrm{kB}$ proteins or interact with other proteins $\mathrm{s}^{44}$ that mask antibody binding.

Next, by immunocytochemical analysis performed with an antibody to the p50 subunit, we found that numerous nuclei of proximal tubular cells were strongly positive for p50 in remnant kidneys in contrast to only occasional tubular p50-positive nuclei in the control cortex. To a much lesser extent, cells in the interstitium, in all likelihood infiltrating inflammatory cells, and glomerular cells positively stained for p50 and thus may partially account for the increased transcription factor activity measured in the remnant kidney.

Another finding of the present study is that concomitant to the activation of NF-kB, a progressive increase in $\mathrm{MCP}-1$ gene expression occurred with time in the kidney of rats with RMR beginning day 7. Intense MCP-1 mRNA signals were detected in tubular epithelial cells and, to a lesser extent, in interstitial infiltrating cells, documented by in situ hybridization experiments. MCP-1 mRNA upregulation preceded the accumulation of ED-1-positive monocytes/macrophages and CD8-positive $T$ lymphocytes in the remnant kidney interstitium, suggesting that in this model, initial mononuclear cell recruitment may occur at least in part by $\mathrm{MCP}-1$-dependent mechanisms. As in remnant kidneys, the progressive increase in NF-kB activation in kidneys of PHN rats was paralleled by increased MCP-1 gene transcription and interstitial mononuclear cell infiltration. In other models of proteinuric nephropathies, renal MCP-1 upregulation has been shown to precede or coincide with infiltration of mononuclear cells into the renal interstitium. ${ }^{17,45}$ That MCP-1 is functionally important in eliciting an interstitial inflammatory response can be derived from the evidence that administering a neutralizing anti-MCP-1 antibody to rats with tubulointerstitial nephritis significantly decreased macrophage infiltration. ${ }^{45}$

If the interstitial inflammatory reaction ensued as a consequence of excess ultrafiltration and proximal tubular reabsorption of proteins that also promoted NF-kB activation and chemokine synthesis, limiting the enhanced protein traffic should also limit NF-kB activation, MCP-1 gene upregulation, and inflammatory cell recruitment. The best strategy to date in experimental animals and humans to reduce protein traffic rests on ACE inhibitors, which additionally limit renal disease progression. ${ }^{2,5,8-14,46}$ To our knowledge, no other intervention is as effective as ACE inhibition in reducing proteinuria. Here, lisino- 
pril administered to rats with remnant kidneys reduced urinary protein excretion, almost completely suppressed NF-kB DNA-binding activity, and reduced by approximately $70 \% \mathrm{MCP}-1$ mRNA expression compared with untreated remnant kidney rats. The accumulation of ED-1positive monocytes/macrophages and CD8-positive $T$ cells in the remnant kidney interstitium was also greatly limited by lisinopril. Similarly, in PHN rats in which the early administration of lisinopril effectively reduced proteinuria, we observed a dramatic decrease of NF- $k B$ activation associated with downregulation of MCP-1 expression and reduction of interstitial mononuclear cell numbers. In line with our hypothesis that NF- $\mathrm{kB}$ activation has a role in the downstream inflammatory reaction rather than itself being a promoter of proteinuria are recent data showing that in rats with Adriamycin nephropathy, chronic treatment with the NF-kB inhibitor, pyrrolidine dithiocarbamate (PDTC), started when animals had overt proteinuria, suppressed cortical NF-kB activation, and markedly reduced interstitial monocyte infiltration, although it did not affect urinary protein excretion rate. ${ }^{47}$

That enhanced protein traffic is a determinant of NF-kB activation and downstream pathways of interstitial inflammation is supported further by the set of experiments using PHN rats with advanced disease and severe proteinuria at the beginning of treatment with high-dose ACE inhibitor. In these animals, lisinopril failed to reduce proteinuria and NF-kB activation. MCP-1 mRNA transcript levels remained abnormally sustained, and inflammatory cell accumulation was not limited by ACE inhibition despite the remarkable effect of high-dose lisinopril in normalizing renal ACE activity and blood pressure.

Previous studies have proposed enhanced angiotensin Il generation as a promoter of NF-kB activation and monocyte infiltration in progressive nephropathies, based on findings that ACE inhibitors limited interstitial inflammation by blunting NF-kB activation and, in turn, MCP-1 overexpression. ${ }^{41,48}$ Although a concomitant role of angiotensin II in promoting NF-kB-dependent pathways of interstitial inflammation cannot be excluded, our present findings in PHN rats with advanced disease that a dose of lisinopril high enough to completely inhibit renal ACE activity failed to reduce proteinuria and NF-kB activation greatly favor the possibility of increased protein traffic as the direct trigger of NF-kB activation.

In summary, we have shown that (1) NF-kB was activated over time in kidneys of rats with $5 / 6$ nephrectomy or PHN, concomitant with the increase in urinary protein excretion; (2) renal expression of MCP-1 mRNA increased during disease progression in parallel with mononuclear cell accumulation in renal interstitium; (3) early treatment with an ACE inhibitor decreased proteinuria and reduced NF-kB activation and MCP-1 overexpression and greatly limited interstitial monocyte/macrophage and T-cell accumulation; and (4) high-dose ACE inhibitor treatment starting in the advanced phase of disease failed to reduce proteinuria, as well as NF- $\mathrm{kB}$ activation and NF-kB-dependent pathways of interstitial inflammation.

\section{ACKNOWLEDGMENT}

The authors thank Dr Donatella Balducci, Dr Elena Gagliandini, and Daniela Rottoli for technical assistance in immunohistochemical surdies.

\section{REFERENCES}

1. Remuzzi G, Bertani $T$ : Is glomenulosclerosis a consequence of altered glomerular permeability to macromolecules? Kidney Int 38:384-394, 1990

2. Remuzzi G, Bertani T: Pathophysiology of progressive nephropathies. N Engl J Med 339:1448-1456, 1998

3. Bertani T, Zoja C, Abbate M, Rossini M, Remuzzi G: Age-related nephropathy and proteinuria in rats with intact kidneys exposed to diets with different protein content. Lab Invest 60:196-204, 1989

4. Magil AB: Tubulointerstitial lesions in human membranous glomerulonephritis: Relationship to proteinuria Am J Kidney Dis 25:375-379, 1995

5. The Gisen Group: Randomised placebo-controlled trial of effect of ramipril on decline in glomerular filtration rate and risk of terminai renal failure in proteinuric, non-diabetic nephropathy. Lancet 349:1857-1863, 1997

6. Wehrmann M, Bohle A, Held H, Schumm G, Kendziorra H, Pressler H: Long-term prognosis of focal sclerosing glomerulonephritis. An analysis of 250 cases with particular regand to tubulointerstitial changes. Clin Nephrol 33:115122,1990

7. Bohle A, Wehrmann M, Bogenschutz $O$, Batz $C$, Muller CA, Muller GA: The pathogenesis of chronic renal failure in diabetic ncphropathy. Investigation of 488 cases of diabetic glomerulosclerosis. Pathol Res Pract 187:251-259, 1991

8. Anderson S, Rennke HG, Brenner BM: Therapeutic advantage of converting enzyme inhibitors in arresting progressive renal disease associated with systemic hypertension in the rat. J Clin Invest 77:1993-2000, 1986 
9. Lafayette RA, Mayer G, Park SK, Meyer TW: Angiotensin 11 receptor blockade limits glomerular injury in rats with reduced renal mass. J Clin Invest 90:766-771, 1992

10. Ots M, Mackenzie HS, Troy JL, Rennke HG, Brenner BM: Effects of combination therapy with enalapril and losartan on the rate of progression of renal injury in rats with 5/6 renal mass ablation. J Am Soc Nephrol 9:224-230, 1998

11. Remuzzi A, Puntorieri S, Battaglia C, Bertani T, Remuzzi G: Angiotensin-converting enzyme inhibition ameliorates glomerular filtration of macromolecules and water and lessens glomerular injury in the rat. $\mathrm{J}$ Clin Invest $85: 541-549,1990$

12. Zoja C, Donadelli R, Corna D, Testa D, Facchinetti D, Maffi R, Luzzana E, Colosio V, Bertani T, Remuzzi G: The renoprotective properties of angiotensin-converting enzyme inhibitors in a chronic model of membranous nephropathy are solely due to the inhibition of angiotensin II: Evidence based on comparative studies with a receptor antagonist. Am J Kidney Dis 29:254-264, 1997

13. Zoja C, Remuzzi A, Corna D, Perico N, Bertani T, Remuzzi G: Renal protective effect of angiotensin-converting enzyme inhibition in aging rats. Am J Med 92:S60-S63, 1992 (suppl 4B)

14. Ruiz-Ortega $M$, Gonzalez $S$, Seron D, Condom $E$, Bustos C, Largo R, Gonzales E, Ortiz A, Egido J: ACE inhibition reduces proteinuria, glomerular lesions and extracellular matrix production in a normotensive rat model of immune complex nephritis. Kidney Int 48:1778-1791, 1995

15. Bertani T, Cutillo F, Zoja C, Broggini M, Remuzzi G; Tubulo-interstitial lesions mediate renal damage in Adriamycin glomerulopathy. Kidney Int 30:488-496, 1986

16. Eddy AA: Interstitial nephritis induced by proteinoverload proteinuria. Am J Pathol 135:719-733, 1989

17. Eddy AA, Giachelli CM: Renal expression of genes that promote interstitial inflammation and fibrosis in rats with protein-overload proteinuria. Kidney Int 47:1546-1557, 1995

18. Lloyd CM, Minto AW, Dorf ME, Proudfoot A, Wells TN, Salant DJ, Gutierrez-Ramos JC: RANTES and monocyte chemoattractant protein-1 (MCP-1) play an important role in the inflammatory phase of crescentic nephritis, but only MCP-1 is involved in crescent formation and interstitial fibrosis. J Exp Med 185:1371-1380, 1997

19. Abbate M, Zoja C, Corna D, Capitanio M, Bertani T, Remuzzi G: In progressive nephropathies, overload of tubular cells with filtered proteins translates glomerular permeability dysfunction into cellular signals of interstitial inflammation. J Am Soc Nephrol 9:1213-1224, 1998

20. Zoja C, Morigi M, Figliuzzi M, Bruzzi I, Oldroyd S, Benigni A, Ronco P, Remuzzi G: Proximal tubular cell synthesis and secretion of endothelin-1 on challenge with albumin and other proteins. Am $J$ Kidney Dis 26:934-941, 1995

21. Wang Y, Chen J, Chen L, Tay YC, Rangan GK, Harris DC: Induction of monocyte chemoattractant protein-1 in proximal tubule cells by urinary protein. J Am Soc Nephrol 8:1537-1545, 1997

22. Zoja C, Donadelli R, Colleoni S, Figliuzzi M, Bonazzola S, Morigi M, Remuzzi G: Protein overload stimulates RANTES production by proximal tubular cells depending on NF-kB activation. Kidney Int 53:1608-1615, 1998
23. Ueda A, Okuda $K$, Ohno S, Shirai A, Igarashi $T$, Matsunaga K, Fukushima J, Kawamoto S, Ishigatsubo Y, Okubo T: NF-kB and Spl regulate transcription of the human monocyte chemoattractant protein-1 gene. I Immunol 153:2052-2063, 1994

24. Nelson PJ, Kim HT, Manning WC, Goralski TJ, Krensky AM: Genomic organization and transcriptional regulation of the RANTES chemokine gene. J Immunol 151:26012612,1993

25. Baeuerle PA, Henkel T: Function and activation of NF-kB in the immune system. Annu Rev Immunol 12:141179,1994

26. Barnes PJ, Karin M: Nuclear factor-kB-A pivotal transcription factor in chronic inflammatory diseases. N Engl J Med 336: 1066-1071, 1997

27. Henkel T, Machleidt T, Alkalay I, Kronke M, BenNeriah Y, Baeuerle PA: Rapid proteolysis of $1 \mathrm{kB}-\alpha$ is necessary for activation of the transcription factor NF-kB. Nature 365:182-185, 1993

28. Wang Y, Rangan GK, Tay Y-C, Harris DCH: Induction of monocyte chemoattractant protein-l by albumin is mediated by nuclear factor $\mathrm{kB}$ in proximal tubule cells. J Am Soc Nephrol 10:1204-1213, 1999

29. Olson JL, Hostetter TH, Rennke HG, Brenner BM, Venkatachalam MA: Altered glomerular permselectivity and progressive sclerosis following extreme ablation of renal mass. Kidney Int 22:112-126, 1982

30. Remuzzi G, Zoja C, Gagliardini E, Corna D, Abbate $\mathrm{M}$, Benigni A: Combining an antiproteinuric approach with mycophenolate mofetil fully suppresses progressive nephropathy of experimental animals. $J$ Am Soc Nephrol 10:15421549,1999

31. Benigni A, Corna D, Maffi R, Benedetti G, Zoja C, Remuzzi G: Renoprotective effect of contemporary blocking of angiotensin II and endothelin-1 in rats with membranous nephropathy. Kidney Int 54:353-359, 1998

32. Read SM, Northcote DH: Minimization of variation in the response to different proteins of the Coomassie blue $G$ dye-binding assay for protein. Anal Biochem 116:53-64, 1981

33. Negoro N, Kanayama $Y$, Haraguchi $M$, Umetani $N$, Nishimura $M$, Konishi $Y$, Iwai J, Okamura $M$, Inove $T$, Takeda T: Blood pressure regulates platelet-derived growth factor A-chain gene expression in vascular smooth muscle cells in vivo. An autocrine mechanism promoting hypertensive vascular hypertrophy. J Clin Invest 95:1140-1150, 1995

34. Satriano J, Schlondorff D: Activation and attenuation of transcription factor NF-kB in mouse glomerular mesangial cells in response to tumor necrosis factor- $\alpha$, immunoglobulin $G$, and adenosine $3^{\prime}: 5^{\prime}$-cyclic monophosphate. Evidence for involvement of reactive oxygen species. J Clin Invest 94:1629-1636, 1994

35. Rambaldi A, Young DC, Griffin JD: Expression of the M-CSF (CSF-1) gene by human monocytes. Blood 69:14091413,1987

36. Rollins BJ, Morrison ED, Stiles CD: Cloning and expression of JE, a gene inducible by platelet-derived growth factor and whose product has cytokine-like properties. Proc Natl Acad Sci U S A 85:3738-3742, 1988

37. Zoja C, Liu XH, Donadelli $R$, Abbate $M$, Testa $D$, Corna D, Taraboletti G, Vecchi A, Dong QG, Rollins BJ, 
Bertani T, Remuzzi G: Renal expression of monocyte chemoattractant protein-1 in lupus autoimmune mice. J Am Soc Nephrol 8:720-729, 1997

38. Morrissey JJ, Klahr S: Enalapril decreases nuclear factor $\mathrm{kB}$ activation in the kidney with ureteral obstruction. Kidney Int 52:926-933, 1997

39. Zoja C, Abbate M, Coma D, Capitanio M, Donadelli R, Bruzzi I, Oldroyd S. Benigni A, Remuzzi G: Pharmacologic control of angiotensin ll ameliorates renal disease while reducing renal TGF- $\alpha$ in experimental mesangioproliferative glomerulonephritis. Am J Kidney Dis 31:453-463, 1998

40. Sakurai H, Hisada $Y$, Ueno $M$, Sugiura $M, K a-$ washima $\mathrm{K}$. Sugita $\mathrm{T}$ : Activation of transcription factor NF-kB in experimental glomerulonephritis in rats. Biochim Biophys Acta 1316:132-138, 1996

41. Ruiz-Ortega M. Bustos C, Hernandez-Presa MA, Lorenzo O, Plaza JJ, Egido J: Angiotensin II participates in mononuclear cell recruitment in experimental immune complex nephritis through nuclear factor- $\mathrm{kB}$ activation and monocyte chenoattractant protein-1 synthesis. J Immunol 161:430439, 1998

42. Wendt TH, Zhang YM, Bierhaus A, Kriegsmann J, Deng $Y$, Waldherr $R$, Teske $T$, Luther $T$, Fünfstück $R$, Nawroth PP. Stein G: Tissue factor expression in an animal model of hydronephrosis. Nephrol Dial Transplant 10:18201828,1995

43. Perkins ND, Schmid RM, Duckett CS, Leung K, Rice NR, Nabel GJ: Distinct combinations of NF-kB subunits determine the specificity of transcriptional activation. Proc Natl Acad Sci U S A 89:1529-1533, 1992

44. Sheppard KA, Rose DW, Haque ZK, Kurokawa R, McInemey E, Westin S, Thanos D, Rosenfeld MG, Glass CK, Collins T: Transcriptional activation by NF-kB requires multiple coactivators. Mol Cell Biol 19:6367-6378, 1999

45. Tang WW, Qi M, Warren JS, Van GY: Chemokine expression in experimental tubulointerstitial nephritis. J Immunol 159:870-876, 1997

46. Ruggenenti P, Perna A, Gherardi G, Gaspari F, Benini $R$, Remuzzi G, on behalf of Gruppo Italiano di Studi Epidemiologici in Nefrologia (GISEN): Renal function and requirement for dialysis in chronic nephropathy patients on long-term ramipril: REIN follow-up trial. Lancet 352:12521256,1998

47. Rangan GK, Wang Y, Tay Y-C, Harris DCH: Inhibition of nuclear factor- $k B$ activation reduces cortical tubulointerstitial injury in proteinuric rats. Kidney Int 56:118-134, 1999

48. Klahr S, Morrissey J: Angiotensin II and gene expression in the kidney. Am J Kidney Dis 31:171-176, 1998 



\title{
CHAPTER 4
}

\section{Antiproteinuric therapy while preventing the abnormal protein traffic in proximal tubule abrogates protein- and complement-dependent interstitial inflammation in experimental renal disease}

\author{
M. Abbate, C. Zoja, D. Rottoli, D. Corna, N. Perico, \\ T. Bertani and G. Remuzzi
}

Journal of the American Society of Nephrology 1999; 10:804-813 


\title{
Antiproteinuric Therapy while Preventing the Abnormal Protein Traffic in Proximal Tubule Abrogates Protein- and Complement-Dependent Interstitial Inflammation in Experimental Renal Disease
}

\author{
MAURO ABBATE,* CARLA ZOJA,* DANIELA ROTTOLI,* DANIELA CORNA,* \\ NORBERTO PERICO, ${ }^{*}{ }^{\dagger}$ TULLIO BERTANI, ${ }^{* \dagger}$ and GIUSEPPE REMUZZI* ${ }^{\dagger}$ \\ *Mario Negri Institute for Pharmacological Research, and ${ }^{\dagger}$ Unit of Nephrology and Dialysis, Azienda \\ Ospedaliera, Ospedali Riuniti di Bergamo, Bergamo, Italy.
}

Abstract. In proteinuric glomerulopathies, the excess traffic of proteins into the renal tubule is a candidate trigger of interstitial inflammatory and immune events leading to progressive injury, and a key target for the renoprotective action of antiproteinuric drugs. Among proteins trafficked to the proximal tubule, the third component of complement (C3) can be activated locally and contribute to inflammation at sites of protein reabsorption. Experiments were performed in rats with renal mass reduction (RMR, 5/6 nephrectomy) with the following aims: $(l)$ to study $\operatorname{Ig}(\mathrm{IgG})$ and complement deposition in proximal tubules, and interstitial macrophage infiltration and MHC class II expression at intervals after surgery by double immunofluorescence analysis; (2) to assess whether lisinopril (angiotensin-converting enzyme inhibitor [ACEi], $25 \mathrm{mg} / \mathrm{L}$ in the drinking water, from either day 1 or day 7) limited $\operatorname{IgG}$ and C3 accumulation and interstitial inflammation at day 30. In 7-d remnant kidneys, intracellular staining for both IgG and C3 was detectable in proximal tubules in focal areas: $\mathrm{C} 3$ was restricted to IgG-positive tubular cells, and there were no interstitial ED-1 macrophage and MHC Il-positive cellular infiltrates. In 14-d and 30-d remnant kidneys, proximal tubular IgG and C3 staining was associated with the appearance of interstitial infiltrates that preferentially localized to areas of tubules positive for both proteins. RMR rats given ACEi had no or limited increases in levels of urinary protein excretion, tubular IgG, and $\mathrm{C} 3$ reactivity, and interstitial cellular infiltrates in kidneys at $30 \mathrm{~d}$, even when ACEi was started from day 7 after surgery. These findings document that $(l)$ in RMR, IgG and $\mathrm{C} 3$ accumulation in proximal tubular cells is followed by leukocyte infiltration and MHC II overexpression in the adjacent interstitium; (2) ACEi while preventing proteinuria limits both tubular accumulation of $\mathrm{IgG}$ and $\mathrm{C} 3$ and interstitial inflammation. The data suggest that $\mathrm{ACE}$ inhibition can be renoprotective by limiting the early abnormal protein traffic in proximal tubule and consequent deleterious effects of excess protein reabsorption, including the accumulation and local activation of complement as well as the induction of chemokines and endothelin genes known to promote interstitial inflammation and fibrosis.
Proteinuric nephropathies can progress to end-stage renal failure independently of the type of initial insult(s). The results of the most recent studies in this field indicate that proteinuria, commonly taken as a marker of severity, is in fact a major if not the best independent predictor of progression of disease $(1,2)$. Years of basic research on common pathways of injury have also led us to consider the underlying ultrafiltration of proteins into the tubule as a likely trigger of cellular events ultimately responsible for irreversible lesions and decline of function (3). In support of this possibility, together with data of

Received July 21, 1998. Accepted October 14, 1998.

Dr. Sharon Anderson served as Guest Editor and supervised the review and final disposition of this manuscript.

Correspondence to Dr. Mauro Abbate, "Mario Negri" Institute for Pharmacological Research, Via Gavazzeni 11, 24125 Bergamo, Italy. Phone: + 39 (35) 319.888; Fax: + 39 (35) 319.331; E-mail: abbate@irfmn.mnegri.it

1046-6673/1004-0804\$03.00/0

Journal of the American Society of Nephrology

Copyright 1999 by the American Society of Nephrology correlations of proteinuria and renal histopathology in humans (4-8), are the results of studies in rat models showing that the disruption of glomerular permselectivity to protein precedes chronic parenchymal damage and that inhibitors of angiotensin-converting enzyme while preventing proteinuria ameliorated renal structural and functional injury (9-15).

Studies to identify cellular processes by which the abnormal trafficking of proteins into the tubule may contribute to the progression of disease have focused on tubulointerstitial lesions, which along with proteinuria well correlated with faster decline of renal function $(4,7,16-19)$. Findings that both proteinuria and protein accumulation in the tubulointerstitium were associated with interstitial inflammation in Adriamycin nephrosis or aging rats $(20,21)$ and that the same effects together were elicited by systemic injections of large amounts of albumin (22) suggested that the increased protein delivery to the tubule may promote recruitment of inflammatory cells into the interstitium. Furthermore, proximal tubular cells cultured in vitro were induced by exposure to excess protein to upregulate 
and release chemokines $(23,24)$ and endothelin (25) into the basolateral medium, a polarized type of secretion that in vivo would act in turn to promote monocyte and lymphocyte recruitment into interstitium and synthesis of extracellular matrix components by fibroblasts. That this may occur in the initial phase of injury is indicated by findings that in kidneys of rats after $5 / 6$ renal mass ablation, albumin and immunoglobulins accumulate in proximal tubular cells early after surgery, and in the tubular regions preferentially surrounded by inflammatory infiltrates into adjacent interstitium thereafter (26). On the whole, these data suggest that excess protein reabsorption in proximal tubular cells activates pathways of interstitial inflammation and fibrosis in the long term.

Among secondary processes leading to interstitial damage in proteinuric conditions, the activation of complement proteins in the proximal tubule has proinflammatory potential and thus a major role to play $(27,28)$. Complement deposits (C3, C5b-9) were found along the luminal side and in proximal tubular cells in kidneys of proteinuric patients (29), as well as in rat kidneys in which the disease was induced by the primarily nonimmune insults, protein overload, and renal mass ablation $(7,22)$. In rats with aminonucleoside nephrosis, complement is pathogenic to the extent that the treatment with soluble complement receptor presumably by inhibiting $\mathrm{C} 3$ activation in proximal tubule attenuated interstitial lesions (27). In addition to activating exogenous complement (30), proximal tubular cells can remarkably synthesize C3 $(31,32)$. Both functional properties are in the same pathway to possibly mediate interstitial inflammation in response to protein load.

If the traffic of circulating proteins and the accumulation of complement components in proximal tubular cells are both linked together to subsequent interstitial injury, then drugs known to limit the abnormal passage of proteins into the tubule should also limit both protein accumulation in proximal tubular cells and interstitial inflammation. The ultimate aim of the present study was to test this hypothesis in a primarily nonimmune model. We performed an immunohistochemical analysis of the remnant kidney after $5 / 6$ renal mass reduction in the rat, with the following specific purposes: (l) to assess whether complement (C3) can be detected in proximal tubular cells in regions of ultrafiltered protein (IgG) accumulation, (2) to compare the localization of $\mathrm{C} 3$ and $\operatorname{IgG}$ in proximal tubules with those of monocyte/macrophages and other infiltrating cells bearing MHC II expression into the interstitium, and (3) to establish whether treatment with the antiproteinuric drug lisinopril limits the accumulation of ultrafiltered proteins and $\mathrm{C3}$ in proximal tubules and early interstitial inflammation in this model.

\section{Materials and Methods \\ Animals}

Male Sprague Dawley, CD-COBS rats of 240 to $260 \mathrm{~g}$ initial body weight were obtained from Charles River SpA (Calco, Italy). Animal care and treatment were conducted in accordance with institutional guidelines that are in compliance with national (D.L. no.116, G.U., suppl 40, 18 Febbraio 1992, Circolare No 8, G.U., 14 Luglio 1994) and international laws and policies (EEC Council Directive 86/609,
OJL 358, Dec 1987; Guide for the Care and Use of Laboratory Animals, U.S. National Research Council, 1996). All animals were housed in a constant temperature room with a 12-h dark 12-h light cycle and fed a standard diet.

\section{Disease Model and Experimental Design}

Renal mass ablation was performed by surgical removal of right kidney and ligation of two or three branches of the left renal artery (33). Age-matched rats were used as controls after sham operation, consisting of a laparotomy and manipulation of renal pedicles only. Three groups of rats with renal mass reduction (groups I, II, and III) were sacrificed at 7, 14, and $30 \mathrm{~d}$ after surgery, respectively; shamoperated controls (group IV) were sacrificed at day 30 . To assess the effects of angiotensin-converting enzyme inhibitor, rats with renal mass reduction received lisinopril ( $25 \mathrm{mg} / \mathrm{L}$ in the drinking water) starting from either day 1 (group V) or day 7 (group VI) after surgery and were sacrificed at day 30 ( $n=4$ each group). Lisinopril at this dose in separate experiments was found to cause significant reduction in systolic BP but not hypotension in rats after $5 / 6$ renal mass ablation (34). Twenty-four hour urine samples were collected in metabolic cages both before the time of disease induction and at sacrifice for determination of urinary protein. Proteinuria was determined by the modified Coomassie blue $G$ dye-binding assay for proteins with bovine serum albumin (BSA) as standard (35).

\section{Tissue Preparation}

At sacrifice, the animals were anesthetized with sodium pentobarbital solution intraperitoneally $(0.1 \mathrm{ml} / 100 \mathrm{~g}$ body wt of a $65 \mathrm{mg} / \mathrm{ml}$ solution), and the kidneys were fixed by perfusion via abdominal aorta (36). Kidneys were first perfused with Hanks' solution for $5 \mathrm{~min}$ and then with periodate-lysine paraformaldehyde fixative (37) for $10 \mathrm{~min}$, followed by overnight immersion in the same fixative at $4^{\circ} \mathrm{C}$. The fragments from remnant kidneys were taken from the center of noninfarcted areas. Fixed tissue specimens were extensively washed with phosphate-buffered saline (PBS) $(0.9 \% \mathrm{NaCl}$ in $10 \mathrm{mM}$ sodium phosphate buffer, $\mathrm{pH}$ 7.4) and stored in the same buffer.

\section{Immunohistochemistry}

Tissue specimens were immersed in $30 \%$ sucrose/PBS for at least $1 \mathrm{~h}$ at room temperature, embedded in OCT medium, and frozen in liquid nitrogen. Tissue sections ( $5 \mu \mathrm{m}$ thick) were cut using a Mikrom $500 \mathrm{O}$ cryostat (Mikrom, Walldorf, Germany) and either stained immediately or stored at $-20^{\circ} \mathrm{C}$ until further processing. Nonspecific binding of antibodies was blocked with PBS/1\% BSA for $15 \mathrm{~min}$ (room temperature). The sections were incubated for direct immunofluorescence with FITC-conjugated goat anti-rat IgG (Jackson; 30 $\mu \mathrm{g} / \mathrm{ml}$ in PBS), FITC goat anti-rat C3 (whole C3) (Cappel, Cochranville, NC; $20 \mu \mathrm{g} / \mathrm{ml}$ ), or Texas Red-anti-rat IgM (Jackson, $30 \mu \mathrm{g} / \mathrm{mI}$ ) for $1 \mathrm{~h}$ at room temperature. After three washes in PBS, slides were mounted using $100 \mathrm{mM}$ Tris-HCl:glycerol 50:50, 2\% N-propyl gallate, $\mathrm{pH} 8$. Sections were examined with a Leika DM-R microscope equipped with epilluorescence and appropriate filters.

Mouse monoclonal antibodies against a cytoplasmic antigen present in rat monocytes and macrophages (EDi) (Serotec, Oxford, United Kingdom) (38) or against rat MHC class II antigen (MHC II) monomorphic determinant (OX-6) (Sera-Lab Lid, Crawley Down, Sussex, United Kingdom) (39) were used for the localization of infiltrating cells and MHC II expression. Tissue sections were blocked with $\mathrm{PBS} / 1 \% \mathrm{BSA}$, incubated overnight at $4^{\circ} \mathrm{C}$ with primary antibody (EDI, $10 \mu \mathrm{g} / \mathrm{ml}$; OX-6, $10 \mu \mathrm{g} / \mathrm{ml}$ ), washed with PBS, and then incubated with $\mathrm{Cy3}$-conjugated donkey anti-mouse $\mathrm{IgG}$ antibodies 
(affinity-purified, absorbed with rat IgG, Jackson ImmunoResearch Laboratories, West Grove, PA; $5 \mu \mathrm{g} / \mathrm{ml}$ in PBS) for $1 \mathrm{~h}$ at room temperature. Double immunofluorescence labeling was performed by the following sequence: mouse monoclonal (EDI, OX-6), Cy3-antimouse IgG, and FITC-anti-rat IgG or FITC-anti-rat C3. In a separate set of incubations on sections of normal kidneys and 30-d remnant kidneys, monoclonal antibody to RECA- 1 antigen present on rat endothelial cells (HIS52, Serotec, Kidlington, United Kingdom; cell supernatant, diluted 1:5) was used to assess the relationship between sites of linear peripheral C3 staining with peritubular capillary structures. Primary antibodies were omitted in control experiments. Absence of cross-reactions between antibodies was further confirmed by comparing individual patterns on adjacent sections or after inversion of the incubation sequences.

\section{Evaluation of Tubular Staining and Comparison with the Distribution of MHC II-Positive Cells and}

\section{ED-1 Macrophages}

Semiquantitative analysis of proximal tubular IgG or C3 staining compared with cells detected by OX- 6 antibody in the same areas was performed by two independent investigators by examining randomly selected fields of view $(\times 400)$ of cortical areas in double-stained sections (26), using the appropriate filters for FITC and Cy3 fluorescence staining, respectively. The total number of proximal tubules and the number of proximal tubules positive for intracellular IgG or $\mathrm{C} 3$ staining were counted in each field (mean number of fields for each animal, 15), and the numbers of OX-6-positive cells in the interstitium were counted in the same fields. Infiltrating ED-1-positive cells were detectable at the sites of OX-6 staining as shown previously in this model (26) and were counted in adjacent sections.

\section{Statistical Analyses}

The results are expressed as mean $\pm S D$. Data were analyzed by ANOVA and multiple comparisons. Statistical significance was defined as $P<0.05$.

\section{Results \\ Localization of Complement $C 3$ and Comparison with Interstitial Sites of Enhanced MHC Class II Antigen Expression and ED-1 Macrophage Infiltration}

The patterns of $\mathrm{C} 3$ staining at intervals after $5 / 6$ renal mass ablation are illustrated in Figures 1 and 2, and the results of semiquantitative analysis are represented in Figure $3 \mathrm{~A}$. In the cortex of control kidneys, C3 reactivity was confined to a linear interrupted staining at the periphery of proximal tubules and some distal segments. No intracellular C3 was detectable in proximal tubular epithelial cells (Figure 1A). In contrast to control kidneys, intracellular $\mathrm{C} 3$ became detectable in remnant kidneys along with $\mathrm{IgG}$ in increasing numbers of proximal tubular profiles at each time point after surgery, and this was paralleled by increasingly high levels of urinary protein excretion $(\mathrm{mg} / \mathrm{d}: 7 \mathrm{~d}, 45.9 \pm 24.8 ; 14 \mathrm{~d}, 143.4 \pm 53.5 ; 30 \mathrm{~d}, 218.8 \pm$ 65.9; sham-operated controls, $21.7 \pm 2.2$ ). At $7 \mathrm{~d}$, granular C3 staining in the cytoplasm of proximal tubular epithelial cells was weak (Figure 1B), and brush border deposits were found in some tubules. At 14 and $30 \mathrm{~d}$ after surgery (Figure 1, C and D), the percentage of proximal tubules positive for $\mathrm{C} 3$ and $\mathrm{IgG}$ staining further increased $(P<0.05$ at both time points compared to $7 \mathrm{~d}$ ). Tubular casts and cell debris also stained for $\mathrm{C} 3$ and IgG. The staining for $\mathrm{C} 3$ in tubules displayed variable intensity and localization to intracellular sites, brush borders, and cell debris. In addition, there were heterogeneous changes in the linear $\mathrm{C} 3$ reactivity at the periphery of the tubules, with partial loss or circumferential staining.

The comparison of intracellular C3 and IgG staining on adjacent sections revealed colocalization to the proximal tubular profiles and overall comparable levels of intensity (Figure 2, A and B). A minor percentage of tubules showing weak or irregular intracellular IgG staining had no $\mathrm{C} 3$ reactivity (mean percentage of tubules stained for both $\mathrm{IgG}$ and $\mathrm{C} 3: 7 \mathrm{~d}, 94.9 \%$; $14 \mathrm{~d}, 95.2 \% ; 30 \mathrm{~d}, 85.8 \%$ ). Besides the localization to intracellular sites consistent with subapical and lysosomal compartments that was common to both proteins, an additional finding at high magnification in the sections stained for $\mathrm{C} 3$ was the presence of granular or diffuse cytoplasmic staining in the basal region of some proximal tubular cells (Figure $2 \mathrm{C}$ ). The linear C3 staining along proximal tubules had apparent basement membrane distribution that was not associated with peritubular capillary structures as revealed by double staining for $\mathrm{C} 3$ (Figure 2C) and RECA-1 antigen (Figure 2D). In control experiments, sections of remnant kidneys did not exhibit any tubular staining for rat IgM (not shown).

The time course of interstitial infiltration of MHC II-positive cells, as detected by OX-6 antibody, and of ED-1-positive monocytes/macrophages is given in Figure 3B. There were significant increases both in the numbers of OX-6-positive cells and ED-1 monocyte/macrophages in 14-d and 30-d remnant kidneys compared with sham-operated rats. Focal ED-1 macrophage infiltrates were found in the peritubular cortical interstitium in all of the rats at these time points, and they clearly localized to the interstitial areas of high MHC II expression by comparison on adjacent sections. Interstitial cellular infiltrates were also recognized both by OX-6 and ED-1 antibodies in perivascular sites and at the vascular pole of glomeruli.

To compare the distribution of the tubular sites positive for C3 with the localization of MHC II and ED-1-positive cellular infiltrates in peritubular interstitium, sections of remnant kidneys were double-immunostained and analyzed for simultaneous detection using secondary antibodies conjugated with FITC or Cy3 (green and red staining, respectively) (Figure 4). As documented previously for comparison with IgG (26), a strict spatial relationship was found between the regions of C3 accumulation in proximal tubules and the interstitial sites of inflammatory cell infiltration both in the 14-d (Figure 4C; compare with control kidney in Panel A and with 7-d remnant kidney in Panel B) and 30-d remnant cortex (Figure 4E). Infiltrates of MHC II-positive cells and ED-1 macrophages were less dense or absent in other peritubular regions. The comparison of the distribution of IgG staining and ED-1 infiltrating cells (Figure 4D) confirmed the same type of association as found for $\mathrm{C3}$ and $\mathrm{MHC}$ II in adjacent sections (Figure $4 \mathrm{C}$ ). Given the heterogeneous intracellular and/or brush border patterns of $\mathrm{C} 3$ within sites of positive staining, it was not possible to establish whether preferential association occurred 

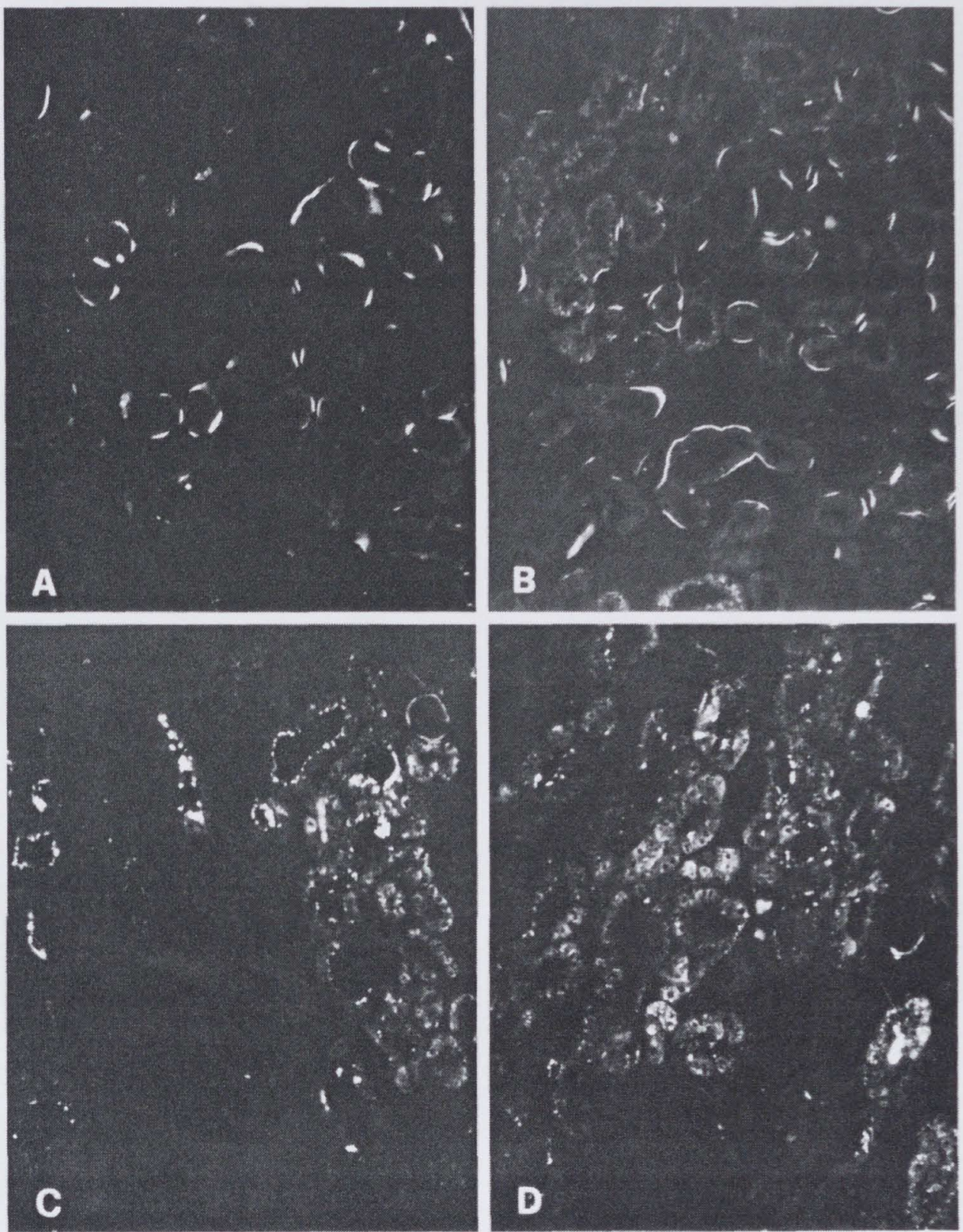

Figure 1. Immunofluorescence analysis of $\mathrm{C} 3$ in cryostat sections of normal rat kidney (A) and remnant kidneys after $5 / 6$ renal mass ablation (B through D). (A) Photomicrograph of normal kidney cortex showing interrupted linear C3 reactivity at the periphery of tubules. Note the absence of intracellular staining. (B) In contrast, an area of a 7-d remnant kidney displays intracellular staining in proximal tubular epithelial cells in addition to the peripheral pattern. In areas of remnant kidneys at 14-d (C) or 30-d (D) after surgery, C3 staining is more diffuse in proximal tubules and detectable in brush borders. The linear peripheral staining of most tubules was attenuated or lost in these areas. The kidneys were fixed by perfusion with periodate-lysine paraformaldehyde, and the sections were stained with FITC-conjugated goat anti-rat C3. Magnification, $\times 250$. 

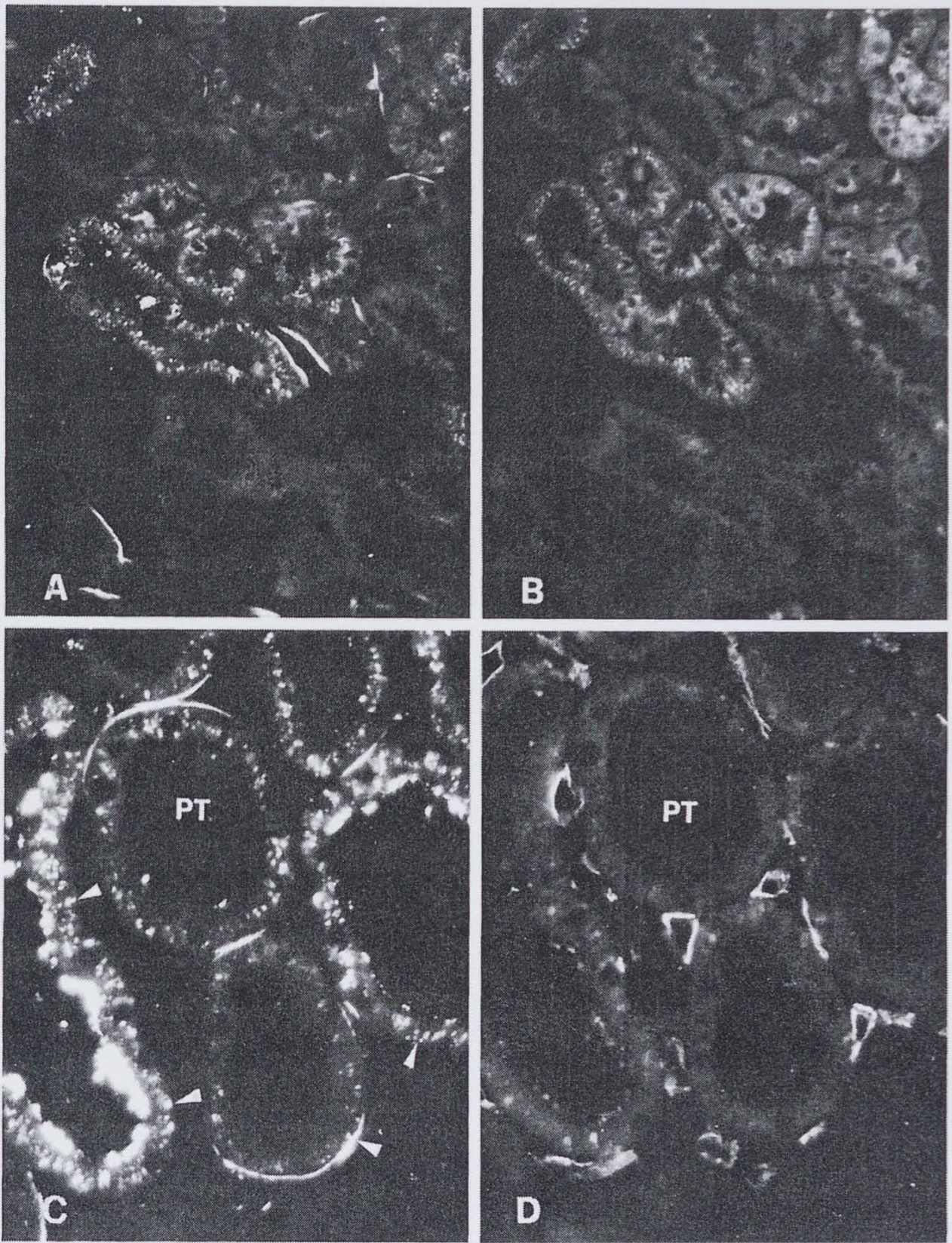

Figure 2. Comparison of $\mathrm{C} 3$ and IgG staining in adjacent sections of cortex of a 30-d remnant kidney ( $\mathrm{A}$ and $\mathrm{B}$ ), and relationship of $\mathrm{C} 3$ peripheral staining with peritubular capillary structures (C and D). Both C3 (A) and IgG (B) are stained in tubular epithelial cells of the same proximal tubules showing prevalent apical or irregular intracellular distribution. (C and D) Linear C3 reactivity at the periphery of tubular profiles is strictly associated with the interstitial aspect of the tubules, and it is not localized to peritubular capillaries in a section that was double-stained for C3 (C) and RECA-1 endothelial cell antigen (D). PT, proximal tubule. Arrowheads in C point to granular staining for C3 in the basal region of the cells. Magnification: $\times 310$ in $\mathrm{A}$ and $\mathrm{B} ; \times 800$ in $\mathrm{C}$ and $\mathrm{D}$. 

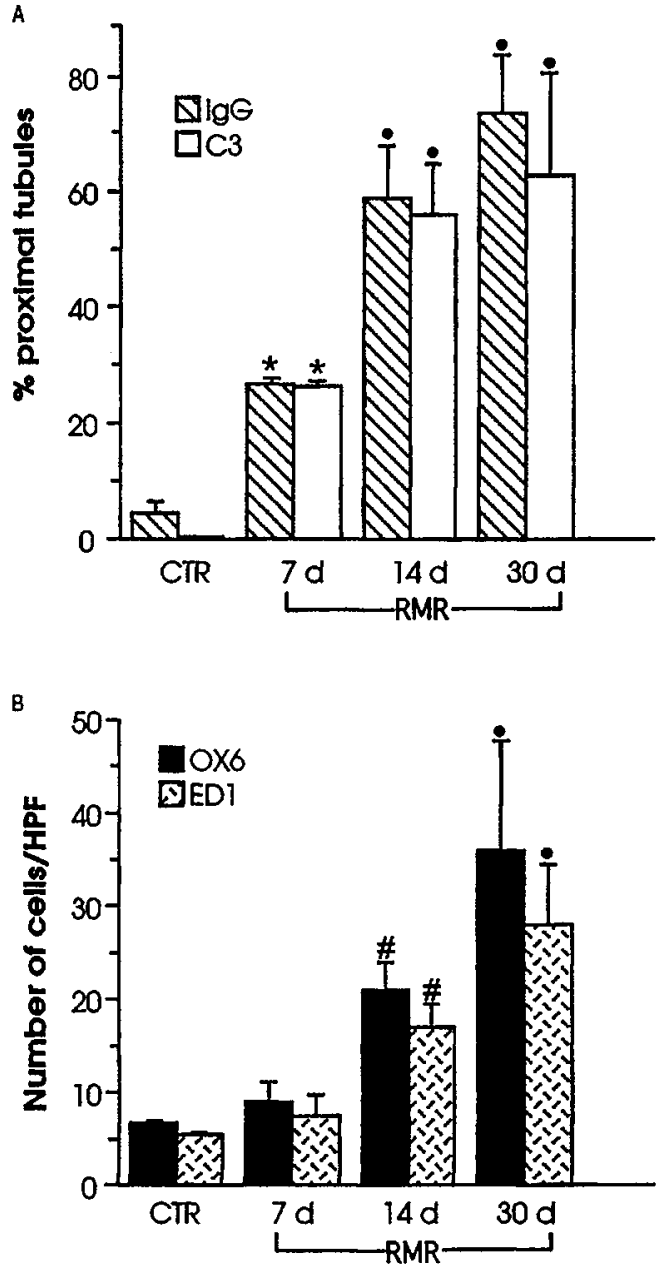

Figure 3. Time course of $\mathrm{IgG}$ and $\mathrm{C} 3$ accumulation in proximal wbules (A) and interstitial cellular infiltration (B) in $5 / 6$ remnant kidneys. OX-6, MHC II-positive cells; ED-1, monocyte/macrophages; HPF, high-power $(\times 400)$ field of vicw: CTR, sham-operated control rats; RMR, rats with $5 / 6$ remnant kidney. ${ }^{*} P<0.01$ versus $\mathrm{CTR}$, ${ }^{\circ} P$ $<0.01$ versus $\mathrm{CTR}$ and 7-d RMR; ${ }^{P}<0.05$ versus $\mathrm{CTR}$ and $7-\mathrm{d}$ RMR.

with either one of these patterns, although this was not apparent.

\section{Effects of Lisinopril on $C 3$ and $\lg G$ Tubular Cell Accumulation and Interstitial Inflammatory Cell Infiltration}

As shown in Table 1, rats given lisinopril from either day 1 or day 7 after surgery had levels of urinary protein excretion at
$30 \mathrm{~d}$ comparable to sham-operated controls, in contrast to the high levels found in the untreated rats with $5 / 6$ remnant kidneys at this time. This effect was associated with limited increases in the percentage of proximal tubular profiles showing positive staining for $\mathrm{IgC}$ and $\mathrm{C} 3$ to levels that were significantly lower in the $5 / 6$ remnant kidneys of rats treated with lisinopril compared with untreated tats with $5 / 6$ remnant kidneys at this time. Thus, the patterns of staining were comparable to those of sham-operated controls in $50 \%$ of rats treated with lisinopril from day 1 (Figure 4F, compare with $5 / 6$ remnant kidney of untreated rat in Figure $4 \mathrm{E}$ ), as well as in one of the rats treated from day 7 . In the other kidneys, abnormal staining for IgG and $\mathrm{C} 3$ was present in variable percentages of tubules and it was overall similar to remnant kidneys at $7 \mathrm{~d}$ after surgery as described in the above section. In the rats treated with lisinopril, numbers of MHC Il-positive cells and ED-1 monocytes/macrophages in remnant peritubular interstitium at $30 \mathrm{~d}$ were also significantly lower than in remnant kidneys of untreated rats, and they were reduced to control values in the rats given lisinopril from day 1 after surgery.

\section{Discussion}

The results of the first set of experiments in the present study show that in rats with proteinuria of glomerular origin due to 5/6 renal mass ablation, intracellular $\mathrm{C} 3$ staining was detectable in proximal tubules in focal areas as early as $7 \mathrm{~d}$ after surgery and was still restricted to proximal tubules at subsequent time points. At variance, in normal kidneys $\mathrm{C} 3$ reactivity was confined to a linear interrupted staining at the periphery of tubules and not detectable within the cells. That the abnormal C3 staining in proximal nubules of remnant kidneys was associated with ultrafiltered protein was indicated by evidence of C3 and $\mathrm{IgG}$ colocalization to the same tubules in adjacent sections. This was also supported in the same experimental model by detection of protein reabsorption droplets in remnant glomenuli (26), reflecting early events of altered glomerular protein traffic. Thus, the combined pattern is consistent with tubular accumulation of ultrafiltered complement as suggested by studies of other rat models of proteinuric nephropathy. Deposition of $\mathrm{C} 3$ in proximal tubules was found in rats with protein overload proteinuria induced by the parenteral administration of heterologous albumin, that develop acute tubulointerstitial nephritis (22). Similarly, in rats with aminonucleoside nephrosis, complement components $\mathrm{C} 3$ and $\mathrm{C} 5 \mathrm{~b}-9$ were found on the luminal side of proximal tubular cells as early as $7 \mathrm{~d}$ after injection of puromycin aminonucleoside (27). Recently. deposition of rat $\mathrm{C} 3$ and $\mathrm{C} 5 \mathrm{~b}-9$ was also observed at the luminal surface and within absorption droplets of proximal tubular cells in the kidneys of proteinuric rats with mesangial proliferative glomerulonephritis (28).

C3 is an essential component of both the classical and alternative pathways of complement activation. In normal kidney, small amounts of $\mathrm{C} 3$ are activated by the cleavage of its internal thiolester bond by the reaction with ammonia (40). The activated $C 3$ can bind to factor $B$, which is cleaved by factor D to form $\mathrm{C} 3$ convertase. Although $\mathrm{C} 3$ convertase has the ability to cleave the $\mathrm{C} 3$ molecule into $\mathrm{C} 3 \mathrm{a}$ and $\mathrm{C} 3 \mathrm{~b}$, further reaction is 

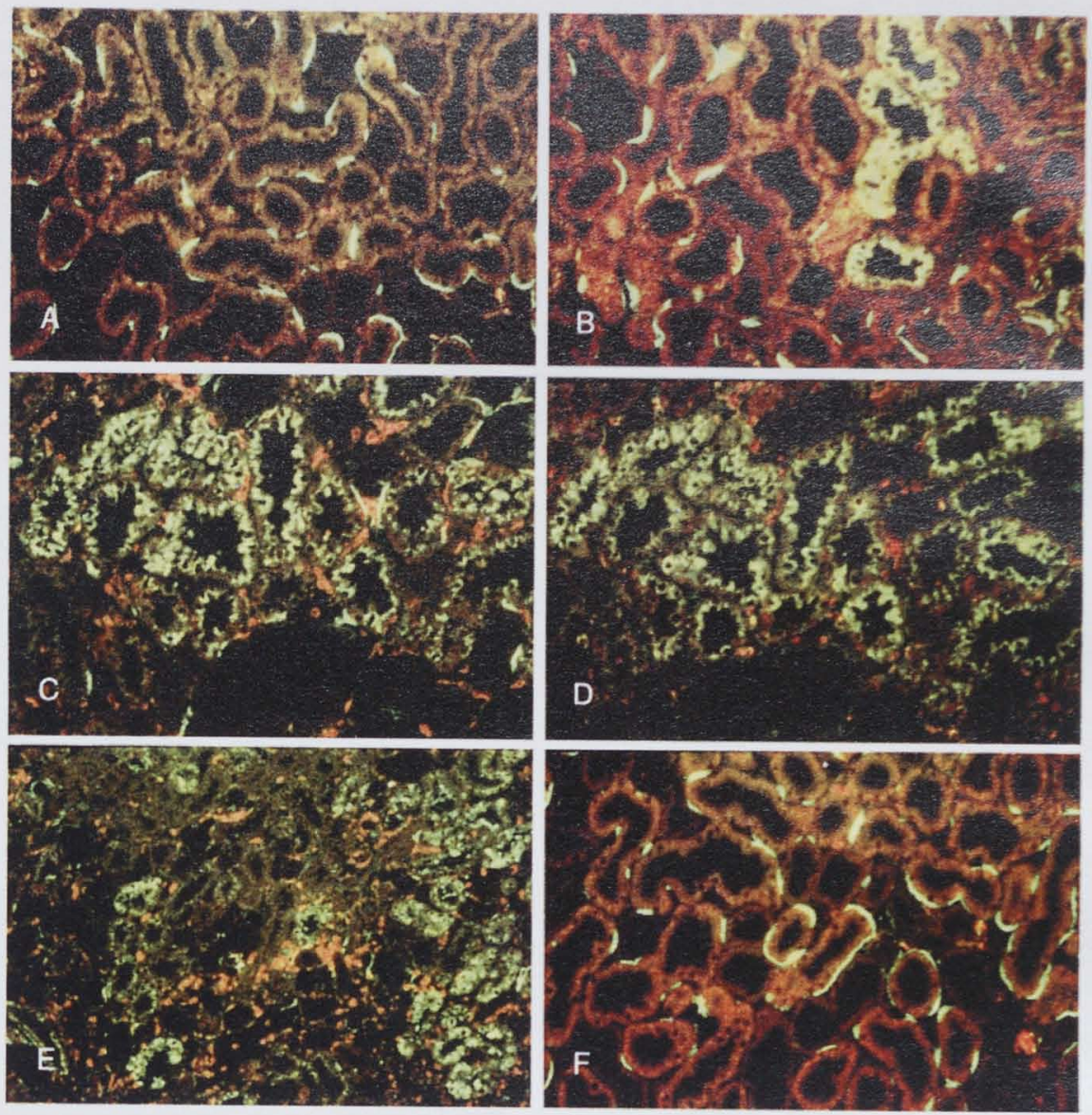

Figure 4. Comparison of C3 staining with interstitial sites of enhanced MHC class II antigen expression (OX-6-positive cells) and ED-1-positive macrophage infiltration, and effects of angiotensin-converting enzyme (ACE) inhibitor on C3 protein accumulation (FITC, green fluorescence) and interstitial inflammation (red fluorescence). Panels A, B, C, and E are representative of results of double immunofluorescence staining for C3 and MHC II antigen in control kidney (A) and remnant kidneys at $7 \mathrm{~d}$ (B), $14 \mathrm{~d}$ (C), or $30 \mathrm{~d}$ (E) after surgery. OX-6-positive cellular infiltrates were present in the peritubular interstitium of $14-\mathrm{d}$ and $30-\mathrm{d}$ remnant kidneys, and had preferential localization at the sites of $\mathrm{C} 3$ protein accumulation. Panel D shows the same area from Panel $\mathrm{C}$ at $14 \mathrm{~d}$ in an adjacent tissue section stained for IgG and ED-1 macrophages. As shown in Panel F, patterns of C3 and OX-6-positive staining were comparable to control in the $5 / 6$ remnant kidney of a rat treated with ACE inhibitor from day 1 and sacrificed at day 30 after surgery. Magnification: $\times 250$ in A, B, C, D, and F; $\times 125$ in E.

usually inhibited by the complement regulatory proteins present on the cell membrane or in plasma (41). However, regulatory proteins active at the level of $\mathrm{C} 3$ convertase were not detectable at the luminal surface of the proximal tubular cells in the normal kidney $(42,43)$. Thus, it is possible that complement components, which are otherwise absent in the tubular lumen, are activated on the apical surface of proximal tubular cells in the proteinuric condition, such that $\mathrm{C} 3$ activation may not be effectively modulated by decay accelerating factor, which is locally induced (43). In vitro evidence is actually available that proximal tubular cells activate complement via the alternative pathway (30) leading to fixation of the C5b-9 MAC neoantigen on the cell surface (44). This, in addition, was followed by cytoskeletal alterations, superoxide anion and hydrogen peroxide production, and synthesis of proinflammatory cytokines such as interleukin-6 and tumor necrosis factor- $\alpha$ (45). Although the generation of C $5 b-9$ on the apical surface can contribute to functional impairment of proximal tubular cells linked to proteinuria, the $\mathrm{C} 3$ component may have additional and independent proinflammatory actions 
Table 1. Effect of ACE inhibitor on proteinuria, accumulation of $\operatorname{lgG}$ and $\mathrm{C} 3$ in proximal tubules, and interstitial infiltration of MHC II-positive cells and ED-1 macrophages in remnant kidneys after $5 / 6$ renal mass ablation ${ }^{2}$

\begin{tabular}{lcccrc}
\hline \multicolumn{1}{c}{ Group } & $\begin{array}{c}\text { Proteinuria } \\
(\mathrm{mg} / \mathrm{d})\end{array}$ & \multicolumn{2}{c}{$\begin{array}{c}\text { IgG } \\
\text { (\% proximal tubules) }\end{array}$} & \multicolumn{2}{c}{$\begin{array}{c}\text { OX-6 (MHC II) } \\
\text { (No. of cells/HPF) }\end{array}$} \\
\hline 30-d RMR & $218.8 \pm 65.9$ & $73.5 \pm 12.0$ & $62.7 \pm 18.9$ & $36.0 \pm 12.9$ & $28.2 \pm 7.2$ \\
30-d RMR + ACEi-(day 1) & $14.3 \pm 5.1^{\mathrm{b}}$ & $6.7 \pm 7.1^{\mathrm{b}}$ & $3.2 \pm 3.7^{\mathrm{b}}$ & $9.2 \pm 4.3^{\mathrm{b}}$ & $8.0 \pm 3.1^{\mathrm{b}}$ \\
30-d RMR + ACEi-(day 7) & $34.4 \pm 18^{\mathrm{b}}$ & $30.7 \pm 22.9^{\mathrm{b}}$ & $7.0 \pm 6.1^{\mathrm{b}}$ & $13.0 \pm 1.8^{\mathrm{b}}$ & $8.6 \pm 1.1^{\mathrm{b}}$ \\
30-d control & $21.7 \pm 2.2^{\mathrm{b}}$ & $4.3 \pm 1.9^{\mathrm{b}}$ & 0 & $6.6 \pm 0.9^{\mathrm{b}}$ & $5.5 \pm 1.3^{\mathrm{b}}$ \\
\hline
\end{tabular}

- Values are mean $\pm S D$. ACE, angiotensin-converting enzyme; RMR, renal mass ablation; ACEi, ACE inhibitor.

${ }^{\mathrm{b}} P<0.01$ versus 30-d RMR. ACE inhibitor treatment was started at day 1 or day 7 up to day 30 after RMR.

in proteinuric settings (46). In this respect, we found evidence of granular $\mathrm{C} 3$ staining in the basolateral region of proximal tubular cells, in addition to intracellular sites consistent with subapical and lysosomal compartments. Such reactivity together with the linear peripheral $\mathrm{C} 3$ staining may reflect polarized secretion of newly synthesized $\mathrm{C} 3$ into the interstitium, a pathway that would reinforce the role of proximal tubular cells as a trigger of tubulointerstitial injury. Previous in vitro studies did show that proximal tubular epithelial cells synthesize complement components including C3 (32). Moreover, exposure of human proximal tubular epithelial cells in culture to serum proteins at the apical surface upregulated C 3 mRNA expression and enhanced the secretion of the protein predominantly at the basolateral site (47). Exactly how excess protein exposure may activate a C3-dependent inflammatory pathway in proximal tubular cells has been theoretically linked, among multiple mechanisms of activation, to excess peptide degradation and consequent ammonia production, in turn leading to activation of alternative pathway, cleavage of unreacted C3, and additional generation of reactive complement components (46). Amidated $\mathrm{C} 3$ is one such molecule that can bind to $\mathrm{CR} 1$ receptors of monocytes and stimulate phagocyte metabolism (6).

Whatever the mechanisms of $\mathrm{C} 3$ accumulation in the proximal tubules, the present study indicates temporal and spatial relationships of intratubular $\mathrm{C} 3$ accumulation with events of interstitial inflammation. Abnormal C3 staining was found in proximal tubular epithelial cells in remnant kidneys at 7-d after surgery in a stage closely preceding the appearance of inflammation. Indeed, interstitial infiltrates of MHC class II-positive cells and ED-1 monocytes/macrophages were first detectable in the peritubular interstitium of 14-d remnant kidneys and then more evident at $30 \mathrm{~d}$. More importantly, in double-stained sections, the infiltrating cells concentrated almost exclusively in regions containing C3-positive proximal tubules, and they were less frequent or absent in other peritubular areas. These findings provide morphologic evidence to implicate complement $\mathrm{C} 3$ activation in the proximal tubule as an early process with potential role in the local recruitment of inflammatory cells at tubular sites of accumulation of filtered plasma proteins.

Our findings also strengthen the general role of complement in the early stages of induction of tubulointerstitial injury as shown in other models $(22,27,28)$. However, complement is not the single factor responsible for the full manifestation of leukocyte recruitment and tubulointerstitial injury even in the immune or toxic models in which the latter was limited by anticomplement reagents $(27,28)$. We suggest that complement proteins may add their pathogenic potential to other proteindependent mechanisms of proximal tubular cell activation in proteinuric disease leading to interstitial inflammation. Actually, in cultured proximal tubular cells, IgG, albumin, or transferrin caused concentration-dependent increases in the transcription of NF- $\mathrm{kB}$-dependent genes for vasoactive and inflammatory mediators (48) and in the rate of synthesis of endothelin-1 (25), a peptide with potent vasoactive and chemotactic properties. Similarly, albumin and transferrin stimulate transcription of the gene for monocyte chemoattractant protein-1 in these cells (23). Albumin and IgG also stimulate the production of RANTES (Regulated upon Activation, Normal T cell Expressed and Secreted) (24), an immunoregulatory cytokine with chemotactic properties for monocytes and memory T cells (49).

If the interstitial inflammatory reaction were the consequence of proximal tubular cell uptake of filtered proteins including C3, limiting protein filtration and reabsorption should prevent tubular cell activation and $\mathrm{C} 3$ accumulation and eventually preserve tubuiointerstitial structure. Drugs that limit the synthesis or biologic activity of angiotensin II have attracted great interest as a result of their unique property of slowing the rate of progression of renal disease $(48,50)$. Consistent experimental and clinical evidence $(14,51)$ tends to suggest that one mechanism for the beneficial effect of ACE inhibitors is related to their ability to reduce glomerular protein traffic. Here we found that the ACE inhibitor lisinopril given to rats with renal mass ablation prevented or stabilized urinary protein excretion, respectively, when treatment was started from day 1 or day 7 after surgery. This functional effect was associated with reduction of $\mathrm{C} 3$ and IgG staining in proximal tubules to comparable levels of sham-operated control rats, and with the normalization of the number of MHC class II-positive cells and monocyte/macrophages in the interstitium at least for animals given lisinopril from day 1 after surgery. These findings offer additional support to the potential role of protein traffic to the induction of tubulointerstitial inflammation in proteinuric renal disease, at least in part via activation of 
proximal tubular cells leading to complement accumulation and new synthesis of proinflammatory molecules including the $\mathrm{C} 3$ component itself. The contribution of tubular $\mathrm{C} 3$ complement is supported by recent data in rats with aminonucleoside nephrosis showing that a soluble form of recombinant human complement receptor type 1 (SCRl), which inhibits complement activation by decay acceleration of $\mathbf{C} 3$ convertase, limited tubulointerstitial cell infiltration and injury (27). Simjlar effects were observed in rats given cobra venom factor to deplete serum complement (27). Interference with complement activation of $\mathrm{C} 3$ convertase with soluble CR 1 presumably by local inhibition at sites of tubular deposition was also effective in reducing the severity of lesions in rats with mesangial proliferative glomerulonephritis (28). Our findings do not exclude the possibility that additional mechanisms of tissue injury can be interrupted by ACE inhibitor while exerting its salutary action, mainly those linked to hemodynamic changes in this model or to the fibrogenic potential of angiotensin 11 (52).

In summary, we have shown that in rats with renal mass ablation ( $l$ ) proteinuria is associated with enhanced protein traffic and $\mathrm{C} 3$ complement accumulation in proximal tubules in the early stage of progressive disease; (2) abnormal accumulation of complement and possibly basolateral secretion of newly synthesized $\mathrm{C} 3$ are followed by macrophage infiltration and $\mathrm{MHC} \mathrm{II}$ overexpression into the peritubular interstitium and may have role in the inflammatory response; (3) inhibition of ACE with lisinopril while limiting the abnormal traffic of complement and other proteins abrogates interstitial inflammation.

Given the role of tubulointerstitial injury in subsequent scarring and renal function impairment, strategies to prevent or retard progression of tubulointerstitial lesions in humans should be focused on the reduction of proteinuria. Future approaches, however, may consider intracellular congestion of proteins and downstream cellular signaling as well as other secondary protein-independent pathways as possible target mechanisms, particularly when permselective properties of glomerular capillary barrier are irreversibly compromised.

\section{Acknowledgment}

We thank Dr. Elena Gagliardini for kind help in the preparation of photomicrographic material.

\section{References}

1. The Gisen Group: Randonised placebo-controlled trial of effect of ramipril on decline in glomerular filtration rate and risk of terminal renal failure in proteinuric, non-diabetic nephropathy. Lancet 349: 1857-1863, 1997

2. Ruggenenti P, Gaspari F, Perna A, Remuzzi G: Cross sectional longitudinal study of spot morning urine protein: Creatinine ratio, 24 hour urine protein excretion rate, glomerular filtration rate, and end stage renal failure in chronic renal disease in patients without diabetes. $\mathrm{Br}$ Med J 316: 504-509, 1998

3. Remuzzi G, Ruggenenti $P$. Benigni A: Understanding the nature of renal disease progression. Kidney Int 51: 2-15, 1997

4. Schainuck LI, Striker GE, Cutler RE, Benditt EP: Structural- functional correlation in renal disease. II. The correlations. Hum Pathol 1: 631-641, 1970

5. Magi] AB: Tubulointerstitial lesions in human membranous glomerulonephritis: Relationship to proteinuria. Am J Kidney Dis 23: 375-379, 1995

6. Isenman DE, Kells DIC, Cooper NR, Muller-Eberhard J, Pangburn MK: Nucleophilic modification of human complement protein C3: Correlation of conformational changes with acquisition of C3b-like functional properties. Biochemistry 20: 4458-4467, 199 !

7. Mackensen-Haen R, Eissele R, Bohle A: Contribution on the correlation between morphometric parameters gained from the renal cortex and renal function in lgA nephritis. Lab Invest 59 : $239-244,1988$

8. Mackensen-Haen S, Bohle A, Christensen J, Wehrmann M, Kendziorra $H$, Kokot $F$ : The consequences for renal function of widening of the interstitium and changes in the tubular epithelium of the renal cortex and outer medulla in various renal diseases. Clin Nephrol 37: 70-77, 1992

9. Anderson S, Diamond JR, Karnovsky MJ, Brenner BM: Mechanisms underlying transition from acute glomerular injury to late glomerular sclerosis in a rat model of nephrotic syndrome. $J$ Clin Invest 82: 1757-1768, 1988

10. Zatz R, Dunn BR, Meyer TW, Anderson S, Rennke HG. Brenner BM: Prevention of diabetic glomerulopathy by pharmacological amelioration of glomerular capillary hypertension. $J$ Clin Invest 77: 1925-1930, 1986

11. Brown DM, Steffes MW, Thibert P, Azar S, Mauer SM: Glomerular manifestations of diabetes in the $\mathrm{BB}$ rat. Metabolism 32: $131-135,1983$

12. Cohen AJ, McCarthy DM, Rossetti RG: Renin sectetion of the spontaneously diabetic rat. Diabetes 35: 341-345, 1986

13. Anderson S, Meyer TW, Rennke HG, Brenner BM: Control of glomerular hypertension limits glomerular injury in rats with reduced renal mass. J Clin Invest 76: 612-619, 1985

14. Remuzzi A, Puntorieri S, Battaglia C, Bertani T, Renuzzi G: Angiotensin converting enzyme inhibition ameliorates glomerular filtration of macromulecules and water and lessens glomerular injury in the rat. $J$ Clin Invest 85: 541-549, 1990

15. Zoja C, Corna D, Bnuzzi I, Foglieni C. Bertani T, Remuzzi G, Benigni A: Passive Heymann nephritis: Evidence that angiotensin-converting enzyme inhibition reduces proteinuria and retards renal structural injury. Exp Nephrol 4: 213-221, 1996

16. D'Amico G: Influence of clinical and histological features on actuarial renal survival in adult patients with idiopathic IgA nephropathy, membranous nephropathy, and membranoproliferative glomerulonephritis: Survey of the recent literature. Am J Kidney Dis 20: 315-323, 1992

17. Wehrmann M, Bohle A, Held H, Schumm G, Kendziorra H, Pressler H: Long-term prognosis of focal sclerosis glomenulonephritis: An analysis of 250 cases with particular regard to tubulointerstitial changes. Clin Nephrol 33: 115-122, 1990

18. Bohle A, Wehmann M, Bogenschutz $\mathrm{O}$, Batz $\mathrm{C}$, Muller CA. Muller GA: The pathogenesis of chronic renal failure in diabetic nephroparhy: Investigation of 488 cases of diabetic glomerulosclerosis. Pathol Res Pract 187: 251-259, 1991

19. Wehrmann M, Bohle A, Bogenschuız O, Eissele R, Freislederer A, Ohlschlegel C, Schumun G, Barz C, Gartner H-V: Long-term prognosis of chronic idiopathic membranous glomerulonephritis. Clin Nephrol 31: 67-76, 1989

20. Berani T, Cutillo F, Zoja C. Broggini M. Remuzzi G: Tubulo- 
interstitial lesions mediate renal damage in Adriamycin glomenulopathy. Kidney Int 30: 488-496, 1986

21. Bertani T, Zoja C, Abbate M, Rossini M, Remuzzi G: Agerelated nephropathy and proteinuria in rats with intact kidneys exposed to diets with different protein contents. Lab Invest 60 : 196-204, 1989

22. Eddy AA, McCulloch L, Adams J, Liu E: Interstitial nephritis induced by protein-overioad proteinuria. Am J Pathol 135: 719733, 1989

23. Wang Y, Chen J, Chen L. Tay Y-C, Rangan GK, Harris DCH: Induction of monocyte chemoattractant protein-1 in proximal tubule cells by urinary protein. J Am Soc Nephrol 8: I537-1545, 1997

24. Zoja C, Donadelli R, Colleoni S, Figliuzzi M, Bonazzola S, Morigi M, Remuzzi G: Protein overload stimulates RANTES production by proximal tubular cells depending on NF- $\kappa$ B activation. Kidney Int 53: 1608-1615, 1998

25. Zoja C, Morigi M, Figliuzzi M, Bruzzi I, Oldroyd S, Benigni A, Ronco PM, Remuzzi G: Proximal tubular cell synthesis and secretion of endothelin-1 on challenge with albumin and other proteins. Am J Kidney Dis 26: 934-941, 1995

26. Abbate M, Zoja C, Corna D, Capitanio M, Bertani T, Remuzzi G: In progressive nephropathies, overload of tubular cells with filtered proteins translates glomerular permeability dysfunction into cellular signals of interstitial inflammation. J Am Soc Nephrol 9: 1213-1224, 1998

27. Nomura A, Morita Y, Maruyama S, Hotta N, Nadai M, Wang L, Hasegawa T, Matsuo S: Role of complement in acute tubulointerstitial injury of rats with aminonucleoside nephrosis. Am $J$ Pathol 151: 539-547, 1997

28. Morita Y, Nomura A, Yuzawa Y, Nishikawa K, Hotta N, Smimizu F, Matsuo $S$ : The role of complement in the pathogenesis of tubulointerstitial lesions in rat mesangial proliferative glomerulonephritis. J Am Soc Nephrol 8: 1363-1372, 1997

29. Camussi G, Stratta P. Mazzucco G, Gaido M, Tetta C, Castello $R$, Rotunno $M$, Vercellone $A$ : In vivo localization of $C 3$ on the brush border of proximal tubules of kidneys from nephrotic patients. Clin Nephrol 23: 134-141, 1985

30. Camussi G, Rotunno M, Segoloni G, Brentjens JR, Andres GA: In vitro alternative pathway activation of complement by the brush border of proximal tubules of normal rat kidney. $J$ Immunol 128: 1659-1663, 1982

31. Sasaki O, Zhou W, Miyazaki M, Abe K, Koji T, Verroust $P$, Tsukasaki S, Ozono Y, Harada T, Nakane PK, Kohno S, Sacks SK: Intraglomerular C3 synthesis in rats with passive Heymann nephritis. Am J Pathol 151: 1249-1256, 1997

32. Brooimans RA, Stegmann APA, van Dorp WT, van der Ark AAJ, van der Woude FJ, van Es LA, Daha MR: Interleukin 2 mediates stimulation of complement $\mathrm{C} 3$ biosynthesis in human proximal tubular epithelial cells. J Clin Invest 88: 379-384, 1991

33. Olson JL, Hostetter TH, Rennke HG, Brenner BM, Venkatachatam MA: Altered glomerular permselectivity and progressive sclerosis following extreme ablation of renal mass. Kidney Int 22: $112-126,1982$

34. Remuzzi G, Zoja C, Gagliardini E, Corna D, Abbate M, Benigni $B$ : Combining an antiproteinuric approach with mycophenolate mofetil fully suppresses progressive nephropathy of experimental animals. J Am Soc Nephrol 1999, in press

35. Read SM, Northcote DH: Minimization of variation in the response to different proteins of the Coomassie blue $\mathrm{G}$ dye-binding assay for protein. Anal Biochem 116: 53-64, 1981
36. Abbate $M$, Bachinsky $D$, Zheng $G$, Stamenkovic I, McLaughlin M, Niles JL, McCluskey RT, Brown D: Location of $g$ p330/ $\alpha_{2}-M$ receptor-associated protein ( $\alpha_{2}$-MRAP) and its binding sites in kidney: Distribution of endogenous $\alpha_{2}$-MRAP is modified by tissue processing. Eur J Cell Biol 61: 139-149, 1993

37. McLean IW, Nakane PF: Periodate-lysine paraformaldebyde fixative: A new fixative for immunoelectron microscopy. $J$ Histochem Cytochem 22: 1077-1083, 1974

38. Yamamoto T, Yamamoto K, Kawasaki K, Yaoita E, Shimizu F, Kihara I: Immunoelectron microscopic demonstration of Thy-1 antigen on the surfaces of mesangial cells in the rat glomerulus. Nephron 43: 293-298, 1986

39. Kaissling B, Le Hir M: Characterization and distribution of interstitial cell types in the renal cortex of rats. Kidney Int 45: 709-720, 1994

40. Hostetter MK, Gordon DL: Biochemistry of C3 and related thioester proteins in infection and inflammation. Rev Infect Dis 9 : 97-109, 1987

41. Hourcade D, Holers VM, Atkinson JP: The regulators of complement activation (RCA) gene cluster. Adv Immunol 45: 381416, 1989

42. Ichida S, Yuzawa Y, Okada H, Yoshioka K, Matsuo S: Localization of the complement regulatory proteins in the normal kidney. Kidney Int 46: 89-96, 1994

43. Abe K, Miyazaki M, Koji T, Furusu A, Ozono Y, Harada T, Sakai $H$, Nakane PK, Kohno S: Expression of decay accelerating factor mRNA and complement C3 mRNA in human diseased kidney. Kidney Int 54: 120-130, 1998

44. Biancone L, David S, Della Pietra V, Montrucchio G, Cambi V, Camussi G: Alternative pathway activation of complement by cultured human proximal tubular epithelial cells. Kidney Int 45: $451-460,1994$

45. David S, Biancone L. Caserta C, Bussolati B, Cambi V, Camussi G: Alternative pathway complement activation induces proinfiammatory activity in human proximal tubular epithelial cells. Nephrol Dial Transplant 12: 51-56, 1997

46. Nath KA, Hostetter MK, Hostetter TH: Pathophysiology of chronic tubulo-interstitial disease in rats: Interactions of dietary acid load, ammonia, and complement component $\mathrm{C} 3$. J Clin Invest 76: 667-675, 1985

47. Tang S, Sheerin NS, Zhou W, Brown Z, Sacks SH: Apical proteins stimulate complement synthesis by cultured human proximal tubular epithelial cells. J Am Soc Nephrol 10: 69-76, 1999

48. Remuzzi G, Bertani T: Pathophysiology of progressive nephropathies. $N$ Engl J Med 339: 1448-1456, 1998

49. Schall TJ, Bacon K, Toy KJ, Goeddel DV: Selective attraction of monocytes and $T$ lymphocytes of the memory phenotype by cytokine RANTES. Nature 347: 669-671, 1990

50. Benigni A, Remuzzi G: Glomerular protein trafficking and progression of renal disease to terminal uremia. Semin Nephrol 16: $151-159,1996$

51. Remuzzi A, Ruggenenti P, Mosconi L, Pata V, Viberti G, Remuzzi $\mathrm{G}$ : Effect of low-dose enalapril on glomerular size-selectivity in human diabetic nephropathy. $J$ Nephrol 6: 36-43, 1993

52. Johnson RJ, Alpers CE, Yoshimura A, Lombardi D, Pritzl D, FloegeJ, Schwartz SM: Renal injury from angiotensin II-mediated hypertension. Hypertension 19: 464-474, 1992 



\section{CHAPTER 5}

\section{Combining an antiproteinuric}

approach with mycophenolate mofetil fully suppresses progressive nephropathy of experimental animals

G. Remuzzi, C. Zoja, E. Gagliardini, D. Corna, M. Abbate and A. Benigni Journal of the American Society of Nephrology 1999; 10:1542-1549 


\title{
Combining an Antiproteinuric Approach with Mycophenolate Mofetil Fully Suppresses Progressive Nephropathy of Experimental Animals
}

\author{
GIUSEPPE REMUZZI,*+ CARLA ZOJA,* ELENA GAGLIARDINI,* \\ DANIELA CORNA,* MAURO ABBATE,* and ARIELA BENIGNI* \\ *Mario Negri Institute for Pharmacological Research and ${ }^{\dagger}$ Unit of Nephrology and Dialysis, Azienda \\ Ospedaliera, Ospedali Riuniti di Bergamo, Bergamo, Italy.
}

\begin{abstract}
Chronic renal diseases progress to organ insuffjciency, which may require replacement therapy within one to three decades even independently of the type of initial insults. In the majority of cases, the degrees of proteinuria and interstitial leukocyte infiltration and scarring are strictly correlated with the rate of disease progression. This study tests the hypothesis that excess intrarenal protein traffic may cause lymphocyte-dependent interstitial injury that, while not fully controlled by antiproteinuric therapy, can be further inhibited by concomitant immunosuppression. A primarily nonimmune model was used to reproduce progressive renal disease due to a critical loss of nephron mass. Angiotensin-converting en-
\end{abstract}

zyme (ACE) inhibitur limited proteinuria, interstitial inflammation, MHC class II antigen expression, and severe lesions. Combined treatment with $A C E$ inhibitor and a specific antilymphocyte agent, mycophenolate mofetil, dramatically attenuated macrophage and $\mathrm{T}$ cell infiltration, MHC-class II overexpression, dendritic cells, and all manifestations of the disease. Evidence of lymphocyte-mcdiated renal injury in the setting of excess protein traffic provides the basis for combining $\mathrm{ACE}$ inhibition and immunosuppression to halt progression of proteinuric kidney disease and minimize the need for dialysis or transplantation.
The accumulation of macrophages and $T$ lymphocytes into the renal interstitium is a common feature of proteinuric nephropathies leading to end-stage fibrosis and organ failure. Cytokine-mediated pathways underlying interstitial inflammation can be activated by the abnormal intrarenal protein traffic that is also responsible for proteinuria, the main clinical predictor of progressive renal disease regardless of etiology (1-3). The specific role for abnormal protein traffic as a common trigger of tubulointerstitial injury was suggested by studies with proximal tubular epithelial cells in culture showing that abumin and other proteins that have trafficked across the glomerular barrier into the urinary tubule can stimulate the cells to synthesize and release mediators responsible for macrophage and lymphocyte recruitment (monocyte chemoattractant protein-1 [MCP-1], RANTES) (4,5) and fibrosis (endothelin) (6). Both in nonimmune and immune models in the rat, including the extensive ablation of the renal mass (7-9), puromycin aminonucleoside nephrosis (10), or passive Heymann nephritis (11), such cytokine $(7,10)$ and endothelin pathways $(8,9,11)$ were activated in the kidney as shown by detection of high mRNA

Reccived October 29, 1998. Accepted January 19.1999.

Dr. Sharon Anderson served as Guest Editor and supervised the review and final disposition of this manuscript.

Correspondence to Dr. Mauro Abbate. "Mario Negri" Institute for PharmacoJogical Research, Via Gavazzeni 11. 24125 Bergamo, Italy. Phune: +39035 319 888; Fax: + 39035319331 ; E-mail: abbate@irfmn.mnegri.it

1046-6673/1007-1542

Journal of the American Socicty of Nephrology

Copyright $\bigcirc 1999$ by the American Suciety of Nephrology and/or protein levels in the stages of interstitial leukocyte infiltration. The pathologic significance of cytokine-recruited leukocytes was strengthened by evidence that the treatment with neutralizing MCP-1 antibodies attenuated the severity of inflammation and renal function impairment (10).

Among antihypertensive drugs, angiotensin-converting enzyme inhibitors ( $\mathrm{ACEi}$ ) have potent antiproteinuric and renoprotective actions both in laboratory animals and in human renal diseases. Thus, in proteinuric patients, the greater the effect of ACEi on proteinuria, the greater the rate of reduction of progressively declining GFR (2). In rat models, ACEi were also found to consistently prevent severe structural injury (12) including interstitial lesions (13-15), presumably by the drug's ability to limit excess protein traffic across the altered glomerular barrier and its deleterious consequences. However, the ultimate step of halting renal disease progression in the long term is not expected to be achieved with ACEi alone. We have reported previously that along with proteinuria and macrophage accumulation into the interstitium, the expression of MHC class II antigen (MHC II) is markedly enhanced in the rat kidney in the peritubular interstitium at the sites of excess protein traffic, even after a primary nonimmune insult (16). This led us to hypothesize that in proteinuric diseases only partially responsive to $\mathrm{ACEi}$, protein-dependent stimuli persist and may trigger MHC-II overexpression and $\mathrm{T}$ lymphocytedependent interstitial reactions. This process should be targeted successfully by concomitant immunosuppressive therapy.

In the present study, we tested the possibility that immune mechanisms have a role in the proteinuric nephropathy of rats 
after reduction of renal mass, in which the progressive renal disease is caused by a nonimmune insult to the kidney. A potentially important role can be played by dendritic cells, highly immunogenic cells of the immune system that capture and process antigens in peripheral organs and initiate immune responses (17). We characterized the mononuclear cell populations infiltrating the interstitium, and compared the effects of combining $\mathrm{ACEi}$ and an antilymphocyte agent versus either drug alone against disease. Both lymphocytes and cells positive for a dendritic cell antigen participate in the interstitial cellular infiltrate. The combined ACEi and immunosuppressive approach abrogates the disease, suggesting the underlying activation of protein-dependent immune mechanisins of renal injury.

\section{Materials and Methods Experimental Design}

Male Sprague Dawjey rats (Charles River Italia, Calco, Italy) with initial body weights of 275 to $320 \mathrm{~g}$ were used in these studies. Animal care and treatment were conducted according to the institutional guidelines that are in compliance with national (D.L. n.116, G.U., suppl 40, 18 febbraio 1992, Circolare No.8, G.U., 14 luglio 1994) and international laws and policies (EEC Council Directive 86/609, OJL358, December 1987; Guide for the Care and Use of Laboratory Animals, U.S. National Research Council, 1996). All animals were housed in a constant-temperature room with a 12-h dack/12-h light cycle and fed a standard diet. Renal mass reduction (RMR) was obtained by right nephrectomy and ligation of two or three branches of the left renal artery under anesthesia according to Olson et al. (18). The first set of experiments was designed to characterize the time course and the cell types infiltrating the remnant interstitiom and to analyze the effect of ACEI on proteinuria and interstilial leukocyte infiltration. Four groups of animals ( $n=4$ each) were sacrificed on days $7,14,30$, and 60 after surgery. Four shamoperated rats served as controls. A group of four RMR rats treated with ACEi (lisinopril, given from day 7 at the daily dose of $25 \mathrm{mg} / \mathrm{L}$ in the drinking water; Merck Sharp \& Dohme, Rome, Italy) was sacrificed on day 60 . Twenty-four-hour urine samples were collected in metabolic cages for the determination of urinary protein excretion.

The second set of experiments was designed to compare the effect of lisinopril, mycophenolate mofetil (MMF), or their combination on proteinuria, leukocyte infiltration, and renal structural and functional damage in this model. Sixty Sprague Dawley rats underwent $5 / 6$ nephreclomy. Seven days after surgery, they were divided into four groups receiving vehicle $(0.5 \%$ carboxymethylcellulose, $n=15$ ), lisinopril ( $25 \mathrm{mg} / \mathrm{L}$ in the drinking water, $n=12$ ), MMF (Roche, 20 $\mathrm{mg} / \mathrm{kg}$ in $0.5 \%$ carboxymethylcellutose by gavage, $n=18$ ), and lisinopril + MMF $(n=15)$ until day 60 . Systolic BP. urinary protein excretion, and serum creatinine were assessed at each time point (days $0.7,14$, and 60 ). At the end of the study, the rats were anesthetized and the kidneys were removed for histology and immunohistology as described below.

\section{Systolic $B P$} (19).

Systolic BP was recorded by tail plethysmography in conscious rats

\section{Urinary Protein Excretion}

Twenty-four-hour samples were collected using metabolic cages, and proteinuria was determined by the modified Coomassie blue $G$ dye-binding assay for proteins with bovine scrum albumin as standard (20).

\section{Serum Creatinine}

Blood was collected from the tail vein of anesthetized animals. Serum was obtained after whole blood clotting and kept frozen at $-20^{\circ} \mathrm{C}$ until assayed. Creatinine was measured by the alkaline picrate method (21).

\section{Renal Histology and Immunohistochemistry}

Light Microscopy. Fragments from remnant kidneys were taken from the center of noninfarcted areas. The specimens were fixed for $6 \mathrm{~h}$ in Dubosq-Brazil, dchydrated in alcohol, and embedded in paraffin. Sections ( $3 \mu \mathrm{m}$ ) were stained with Masson's trichrome, bematoxylin and eosin, and periodic acid-Schiff reagent (PAS stain). Tubular (atrophy, casts, and dilation) and interstitial (fibrosis and inflammation) changes were graded on a scale of 0 to $4+(0$. no changes; $1+$, changes affecting $<25 \%$ of the sample; $2+$, changes affecting 25 to $50 \%$ of the sample; $3+$, changes affecting 50 to $75 \%$ of the sample: $4+$, changes affecting 75 to $100 \%$ of the sample). At least 100 glomeruli were examined for each animal, and the extent of glomerular damage was expressed as the percentage of glomeruli presenting focal or global sclerotic lesions. All renal biopsies were analyzed by the same patholugist who was unaware of the nature of the experimental groups.

Immunohistochemical Analysis. Mouse monoclonal antibodies were used for the immunohistochemical detection of the following antigens: ( $I$ ) EDl antigen present in rat monocytes and macrophages (Chemicon, Temecula, CA); (2) a rat MHC class Il antigen monomorphic determinant (OX6) (Serotec, Oxford. United Kingdom); (3) $\mathrm{CD} 4+$ cell surface glycoprotein, a $55-\mathrm{kD}$ molecule expressed by helper T cells, thymocytes, and macrophages (W3/25) (Serotec); (4) rat $C D 8+$ cell surface glycoprotein expressed by $T$ suppressor cells (OX8) (Chemicon); and (5) an $\alpha$-like integrin subunit on rat dendritic cells (OX62) (Serotec) (17,22). Detection of EDI antigen was performed on paraffin sections using an alkaline phosphatase-Fast Red technique as described (23). The slides were heated twice for $5 \mathrm{~min}$ in $0.01 \mathrm{~mol} / \mathrm{L}$ sodium citrate buffer, $\mathrm{pH} 6.0$, at an operating frequency of $2450 \mathrm{MHz}$ and $600-\mathrm{W}$ power output of a microwave oven. They were allowed to cool for $15 \mathrm{~min}$, then rinsed in distilled water twice and in phosphate-buffered saline (PBS) for $5 \mathrm{~min}$. The sections were then incubated with the primary antibody for $\mathrm{l} \mathrm{h}$ at room temperature. After washing in PBS, biotinylated sheep anti-mouse IgG (Boehringer Mannheim Biochemica, Mannheim, Germany) was applied for $30 \mathrm{~min}$ at room temperature. Sections were washed with PBS and incubated with alkaline phosphatase-conjugated streptavidin (Boehringer Mannheim Biochemica) for $30 \mathrm{~min}$ at room tcmperature. followed by washes with PBS and by development with Fast Red substrate (Boehringer Mannheim Biochemica). Sections were counterstained with Harris-type hematoxylin and mounted using an aqueous mounting medium (Bio-Optica, Milan, Italy).

Other leukocyte markers and MHC class II antigens were analyzed by indirect immunofluorescence technique. The tissue fragments were fruzen in liquid nitrogen. Tissue sections ( $5 \mu \mathrm{m}$ thick) were cut using a Mikrom $500 \mathrm{O}$ cryostat (Walldorf, Germany). The sections were blocked with PBS/I\% BSA, incubated overnight at $4^{\circ} \mathrm{C}$ with the primary antibody $(\mathrm{W} 3 / 25,40 \mu \mathrm{g} / \mathrm{ml}$; OX8, 1:100: OX6, $5 \mu \mathrm{g} / \mathrm{ml}$; OX62. $10 \mu \mathrm{g} / \mathrm{ml}$ ), washed with PBS, and then incubated with Cy3conjugated donkey anti-mouse IgG antibodies (aftinity-purified. absorbed with rat IgG, $5 \mu \mathrm{g} / \mathrm{ml}$ in PBS: Jackson ImmunoResearch, West Grove, PA) for $1 \mathrm{~h}$ at room temperature. For each marker, the number 
of cells was counted in at least 10 randomly selected high-power microscopic fields $(\times 400)$ for each animal.

\section{Statistical Analyses}

Results are expressed as mean \pm SEM. Data were analyzed using the nonparametric Kruskal-Wallis test for multiple comparisons. The statistical significance level was defined as $P<0.05$.

\section{Results}

\section{Analysis of Immune and Inflammatory Cellular} Infiltrates in the Remnant Kidney and Effects of Antiproteinuric Drug Therapy

The time course of inflammatory cell infiltration into the interstitium, its relationship with proteinuria, and the effect of lisinopril on these parameters are shown in Figure 1. Rats with RMR developed progressively high levels of urinary protein excretion that were significantly increased compared with sham-operated rats starting from day 7 after surgery. The

\begin{tabular}{|cccccc|}
\hline \multicolumn{5}{c|}{ Usthary profeln excretton (ma/day) } \\
18.2 & $34.7^{\circ}$ & $91.9^{\circ}$ & $190.7^{*}$ & $408.1^{*}$ & $47.2^{\circ}$ \\
\pm 0.8 & \pm 6.5 & $\pm 4.9^{\circ}$ & \pm 18.2 & $\pm 43.6^{\circ}$ & \pm 13.7 \\
\hline
\end{tabular}
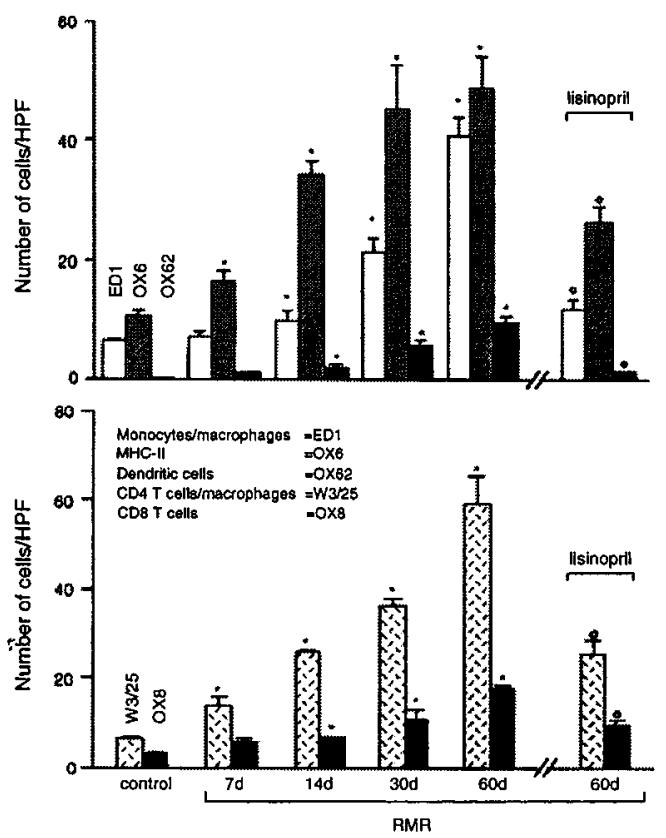

Figure 1. Concomitant increase of urinary protein excretion levels and inflammatory cell infiltrates in the renmant kidney over time and effect of the angiotensin-converting enzyme (ACE) inhibitor lisinopril. The number of infiltrating cells progtessively increased in remnant kidneys, while lessened by ACE inhibitor treatment. ${ }^{*} P<0.05$ for renal mass reduction (RMR) rats versus controls. ${ }^{\circ} P<0.05$ for RMR rats treated with lisinopril versus RMR on day 60. increase in urinary protein excretion over time was associated with the accumulation of increasingly high numbers of cells expressing $\mathrm{MHC}$ class II antigen into the cortical interstitium, confirming our previous findings in this model (16). ED1positive cells (monocytes/macrophages) were a major component of the interstitial cellular infiltrate, and their numbers increased significantly from day 14 after surgery. Increased numbers of cells with CD4 or CD8 phenotype were found in the remnant kidney interstitium from day 7 , together with the appearance of OX62-positive cells, which were absent in the kidneys of sham-operated rats. The numbers of all of these cell types further increased at subsequent time points, in parallel with increasing levels of proteinuria.

Lisinopril given from day 7 after surgery attenuated the increases both in urinary protein excretion and in infiltrating macrophage and $T$ cell numbers compared with untreated RMR rats (RMR vehicle versus lisinopril, EDI: $40 \pm 5$ versus $12 \pm 2, \mathrm{CD} 4: 59 \pm 6$ versus $25 \pm 3, \mathrm{CD} 8: 17 \pm 2$ versus $10 \pm$ 1 cells/high-power field; $P<0.05$ ). The numbers of $\mathrm{MHC}$ II-positive cells and of dendritic cells were also reduced significantly in RMR rats treated with lisinopril (OX6: $49 \pm 5$ versus $26 \pm 3$, OX62: $10 \pm 2$ versus $2 \pm 1 ; P<0.05$ ).

\section{Comparison of the Effects of Lisinopril, $M M F$, and Their Combination on the Renal Disease of Rats with Remnant Kidney}

These experiments were designed to assess whether concomitant immunosuppression from day 7 after surgery may further attenuate lymphocyte-dependent injury that was not fully prevented by antiproteinuric therapy alone.

Rats with RMR given vehicle, MMF, or combined lisinopril and MMF gained weight in a comparable manner (day 60 , vehicle: $428 \pm 15 ;$ MMF: $411 \pm 15$; lisinopril + MMF: $412 \pm$ $10 \mathrm{~g})$. Rats treated with lisinopril tended to grow more than the other groups (468 $\pm 7 \mathrm{~g}, P<0.05$ ).

Urinary Protein Excretion. Lisinopril reduced urinary protein excretion both over vehicle and MMF alone at a statistically significant extent (lisinopril $64 \pm 15$ versus MMF

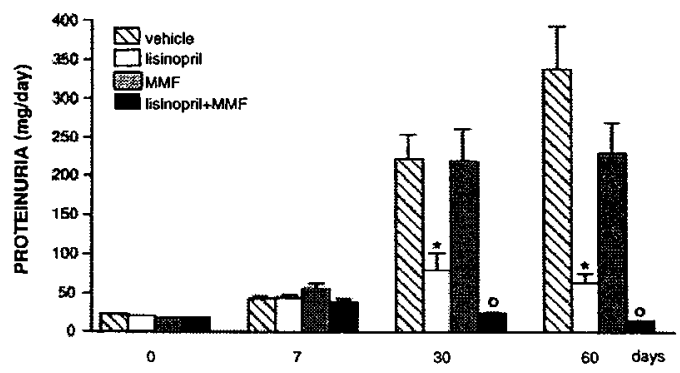

Figure 2. Time course of urinary protein excretion in RMR rats given vehicle $(n=15)$, lisinopril ( $n=12)$, mycophenolate mofetil (MMF) $(n=18)$, or lisinopril + MMF $(n=15)$. Results are mean \pm SEM. ${ }^{*} P<0.01$ for RMR rats treated with lisinopril versus vehicle and MMF. ${ }^{\circ}<0.01$ for RMR rats treated with the combined therapy versus the other groups. 
$229 \pm 45$, or vehicle $336 \pm 62 \mathrm{mg} / \mathrm{d}$ ) (Figure 2). MMF had a mild lowering effect on proteinuria detectable at $60 \mathrm{~d}$ after surgery that, however, did not reach significance. In contrast. both at 30 and $60 \mathrm{~d}$ the combined lisinopril and MMF therapy reduced urinary protein excretion more effectively than single drugs to very low levels comparable to baseline $(16 \pm 4 \mathrm{mg} / \mathrm{d}$, $P<0.01$ versus the other groups) (Figure 2).

Immunohistology. The results of the analysis of mononuclear cell subpopulations at day 60 are summarized in Table 1. Lisinopril markedly reduced the numbers of infiltrating ED1+, $\mathrm{CD} 4+, \mathrm{CD} 8+$, or OX62+ cells, as well as cells expressing MHC II antigen compared with vehicle. MMF treatment was also effective in reducing the numbers of infiltrating cells into the interstitium. However, MMF caused a less marked reduction of ED1,+ MHC II + , and OX62 + cells $(P<0.05$ versus lisinopril); in contrast, CD8 + cells and CD4 + cells were more effectively reduced by MMF ( $P<0.05$ versus lisinopril).

The combined lisinopril and MMF treatment dramatically attenuated the interstitial accumulation of all infiltrating cell types as well as the overexpression of MHC Il antigen at the end of the study more effectively than any other treatment (Table 1).

Renal Funetion and Pathology. In RMR rats given lisinopril or the combined lisinopril and MMF treatment, serum creatinine levels at $60 \mathrm{~d}$ after surgery were lower than in the vehicle group $(P<0.05$ and $P<0.01$ versits vehicle, respectively). In contrast, in animals given MMF, serum creatinine values remained similar to those measured in vehicle rats (Table 2).

The inspection of periodic acid-Schiff-stained sections of kidney cortex of vehicle-treated rats at $60 \mathrm{~d}$ after surgery revealed the presence of glomerular sclerotic lesions, tubular dilation, atrophy, proteinaceous casts in tubular lumina, and areas of interstitial hypercellularity and tibrosis. Sclerotic lesions were present in $62 \%$ of glomeruli, and the mean score for tubulointerstitial damage was 2.4 in rats receiving vehicle (Table 2, Figure 3A). Lisinopril consistently reduced both the frequency of glomerular sclerosis ( $9 \%$ ) and rubulointerstitial damage (score: 0.9$)(P<0.01$ versus vehicle and MMF) (Figure 3B). MMF was less effective in attenuating the exten-
Table 2. Serum creatinine and renal histology in rats with remnant kidney untreated or treated with lisinopril and $\mathrm{MMF}^{\mathrm{a}}$

\begin{tabular}{lccc}
\hline \multicolumn{1}{c}{ Group } & $\begin{array}{c}\text { Serum } \\
\text { Creatinine } \\
(\mathrm{mg} / \mathrm{dl})\end{array}$ & $\begin{array}{c}\text { Glomeruli } \\
\text { with } \\
\text { Sclerotic } \\
\text { Changes } \\
(\%)\end{array}$ & $\begin{array}{c}\text { Tubulointerstitial } \\
\text { Damage } \\
\text { (score) }\end{array}$ \\
\hline Vehicle & $1.6 \pm 0.2$ & $62 \pm 9$ & $2.4 \pm 0.3$ \\
Lisinopril & $1.0 \pm 0.1^{\mathrm{b}}$ & $9 \pm 2^{\mathrm{c}}$ & $0.9 \pm 0.2^{\mathrm{c}}$ \\
MMF & $1.3 \pm 0.2$ & $41 \pm 9$ & $1.8 \pm 0.3$ \\
Lisinopril + MMF & $0.8 \pm 0.1^{\text {d.e }}$ & $2 \pm 1^{\mathrm{f}}$ & $0.5 \pm 0.1^{\mathrm{c}}$ \\
\hline
\end{tabular}

\footnotetext{
Values are mean \pm SEM at day 60 .

${ }^{b} P<0.05$ versus vehicle.

c $P<0.01$ versus vehicle and MMF

${ }^{d} P<0.01$ versus vehicle.

e $P<0.05$ versus MMF.

f $P<0.01$ versus other groups.
}

sion and severity of lesions (41\%; score: 1.8 ) (Figure 3C). In contrast, the combination of lisinopril and MMF fully prevented interstitial cellular infiltration and both glomerular sclerosis (2\%; $P<0.01$ versus the other groups) and tubulointerstitial damage (score: $0.5 ; P<0.01$ versus vehicle and MMF) (Figure 3D). No significant histologic changes were found in kidneys of sham-operated rats (not shown).

Blood Pressure. Vehicle-treated animals developed hypertension (182 $\pm 11 \mathrm{mmHg}$ ). Lisinopril, but not MMF, controlled systolic BP (139 $\pm 10 \mathrm{mmHg})$. Combined administration of Jisinopril and MMF had a remarkable antihypertensive effect maintaining systolic $B P$ at $109 \pm 6 \mathrm{mmHg}$, a mean value lower than normal range (110 to $135 \mathrm{mmHg}$ ) (Figure 4).

\section{Discussion}

Results of immunohistology in this study show that cells of the immune system accumulate into the renal interstitium in rats after $5 / 6$ nephrectomy, a paradigm model for progressive proteinuria and renal parenchymal injury (24). The feature of lymphocyte and macrophage infiltration is shared with immune

Table 1. Effect of lisinopril, mycophenolate mofetil (MMF), and their combination on immunostaining of ED1 + macrophages, CD4+ and CD8 + cells, OX6 $+(\mathrm{MHC} 11+)$ cells, and $\mathrm{OX62}+$ cells $^{\mathrm{a}}$

\begin{tabular}{lccccc}
\hline \multicolumn{1}{c}{ Group } & ED1+ & CD4+ & CD8 & OX6+ & OX62+ \\
\hline Vehicle & $42 \pm 4$ & $49 \pm 4$ & $16 \pm 3$ & $50 \pm 4$ & $10 \pm 1.3$ \\
Lisinopril & $11 \pm 1^{\text {b.c }}$ & $22 \pm 1^{\mathrm{b}}$ & $7 \pm 0.6^{\mathrm{b}}$ & $26 \pm 2.0^{\mathrm{c.d}}$ & $2 \pm 0.3^{\text {c.d }}$ \\
MMF & $17 \pm 2^{\mathrm{b}}$ & $18 \pm 1^{\mathrm{b} . \mathrm{c}}$ & $3 \pm 0.3^{\mathrm{b} . \mathrm{c}}$ & $33 \pm 1.0^{\mathrm{d}}$ & $7 \pm 0.5^{\mathrm{d}}$ \\
Lisinopril + MMF & $5 \pm 1^{\mathrm{f}}$ & $13 \pm 1^{\mathrm{b}}$ & $1 \pm 0.1^{\mathrm{b}}$ & $16 \pm 1.0^{\mathrm{g}}$ & $1 \pm 0.1^{\mathrm{g}}$ \\
\hline
\end{tabular}

\footnotetext{
"Data are expressed as mean \pm SEM (cells/high-power field).

${ }^{b} P<0.01$ versiss vehicle.

c $P<0.05$ iersus MMF.

' $P<0.05$ versus vehicle.

${ }^{c} P<0.05$ versus lisinopril.

${ }^{r} P<0.01$ verstes other groups.

s $P<0.05$ versus other groups.
} 

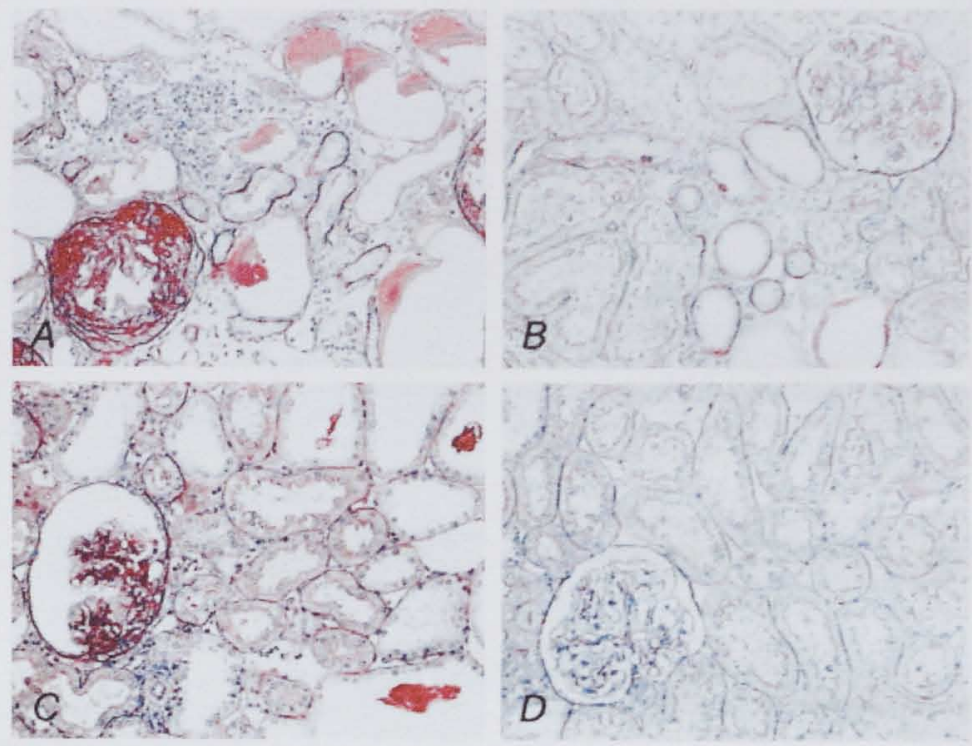

Figure 3. Light microscopy of periodic acid-Schiff-stained sections of renal cortex at $60 \mathrm{~d}$ after $5 / 6$ nephrectomy, representative of rats receiving vehicle (A), lisinopril (B), MMF (C), or combined lisinopril + MMF (D) from day 7. Magnification, $\times 125$.

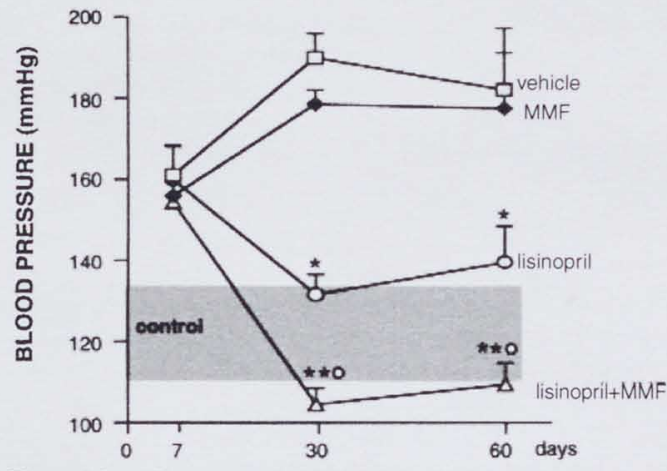

Figure 4. Systolic BP measured during a $60-$ d observation in rats with $5 / 6$ nephrectomy. ${ }^{*} P<0.05$ versus vehicle; ${ }^{* * P}<0.01$ versus vehicle; ${ }^{\circ} P<0.05$ versus lisinopril or $\mathrm{MMF}$ alone.

diseases of the kidney that have intrinsic tendency to progress to the loss of renal function. In the remnant kidney and other proteinuric rat models, however, immune cell infiltration and tubulointerstitial injury are not caused by a primary immune insult. Evidence from clinical studies, as well as data on animal models and cell culture systems, led us to suggest that the enhanced passage of proteins across the giomerular barrier due to any insult to the filtration compartment, including the hemodynamic abnormalities found in remnant kidneys, may exert deleterious effects on the kidney and promote disease progres- sion in part by eliciting a mononuclear cell inflammatory reaction $(1,25,26)$. In this respect, we have recently documented that in the early phase of injury, macrophages and other cells expressing high MHC class II levels accumulate into the peritubular interstitium at the sites of tubular epithelial cell loading with proteins that are ultrafiltered in abnormal amounts and reabsorbed by proximal tubules (16). CD4+ and CD8+ lymphocytes and macrophages were found to accumulate into the renal interstitium in animals in which the hyperfiltration of proteins in the renal tubule was induced by repeated injections of albumin (27). Here, the early concomitant increases in the numbers of ED1 macrophages, OX62+ dendritic cells, and CD4 + and CD8 + lymphocytes as detected in the interstitium at $7 \mathrm{~d}$, when animals were already proteinuric, point to putative roles for the interaction of lymphocytes, macrophages, and specialized antigen-presenting cells in immunologic processes possibly linked to endogenous protein processing and unfolding.

Proteinuria is the best predictor of disease progression to organ failure and can be uniquely lowered by ACEi independently of the underlying etiology (1-3). We found that antiproteinuric therapy by lisinopril given from day 7 after surgery attenuated the increases both in urinary protein excretion and in macrophage and $\mathrm{T}$ cell numbers in the interstitium. Enhanced $\mathrm{MHC}$ class $\mathrm{U}$ expression and numbers of dendritic cells were also limited by lisinopril. No studies found evidence to support direct anti-inflammatory or immunosuppressive effects of lisinopril. ACEi are known to ameliorate the function of the glomerular barrier to protein, thus preventing protein traffic in 
proximal tubule $(1,28)$. ACEi also control glomerular capillary pressure, which is increased as a consequence of functional adaptation to loss of functional kidney mass (12), and is in turn a factor leading to excess protein traffic (29). In proteinuric disease elicited by either immune or nonimmune insults, macrophage and $T$ cell accumulation into the renal interstitium can be caused by locally upregulated chemoattractant cytokines and other proinflammatory molecules of tubular epithelial cell origin $(4,5)$, and by activated ultrafiltered proteins themselves $(30,31)$. Such pathways, thus limited by antiproteinuric action of ACEi in remnant kidney, include enhanced gene expression for the macrophage, lymphocyte, and dendritic cell attractant MCP-1 (4), as well as for tumor necrosis factor- $\alpha$ (32) and osteopontin (16), and activation of complement C3 (30).

Nexi, because our data suggested that lymphocytes may contribute to tubulointerstitial injury despite no primary immune insult and that the accumulation of lymphocytes into the interstitium can be reduced by antiproteinuric therapy, we assessed the effects of a specific immunosuppressant agent versus $\mathrm{ACEi}$ and the potential therapeutic advantage of their combination to simultaneously interfere with lymphocyte function and with the protein traffic determinant of interstitial inflammation. MMF selectively inhibits lymphocyte proliferation among eukaryotic cells by inhibition of purine metabolism (33). MMF has been successfully used in human renal transplantation $(34,35)$, it is well tolerated $(34,35)$, and is being tested for other immune renal diseases in which antiproteinuric therapy may be recommended. We found that MMF greatly limited the accumulation of CD4+ and CD8+ cells. CD8+ lymphocytes were even lowered to control values, an effect predicted by the MMF action of inbibiting the generation of cytotoxic $T$ cells (33). The associated reduction of infiltrating macrophages and MHC class II + expression by MMF, reminiscent of studies in other models $(36,37)$, can occur by virtue of secondary effects of lymphocyte inhibition with consequent perturbed $T$ cell-dependent macrophage recruitment, as well as by impaired glycosylation of adhesion molecules (33). In contrast to jisinopril, however, MMF had little effect on protein traffic as reflected by persistent high proteinuria, and it was consistently less effective in reducing structural and functional damage at day 60 . In particular, the glomerular sclerotic lesions, which often, but not exclusively, develop at the site of abnormal protein ultrafiltration, were only reduced by $30 \%$ by MMF vis-a-vis over $80 \%$ by lisinopril. MMF had no effect on systemic BP, suggesting that the partial beneficial effect of MMF alone was not due to interference with hemodynamic mechanisms of injury in this model. Comparing the immunohistology data, it is interesting that the numbers of macrophages and remarkably dendritic cells, as well as MHC class II+ expression, were significantly lower in the remnant interstitium of rats receiving lisinopril compared with MMF, suggesting that the upstream mechanism of protein traffic determinant possibly controlled by lisinopril is critical both to initiate and maintain severe inflammation and immune injury.

The combined lisinopril and MMF treatment dramatically lowered urinary protein excretion to normal levels and suppressed interstitial accumulation of macrophages, $T$ cells, den- dritic cells, and MHC class II overexpression at the end of the experiment to degrees that were comparable and even lower than those found in RMR rats at $7 \mathrm{~d}$, when treatment was started. Remarkably, the combined treatment also preserved glomerular and tubular structural integrity, as well as renal function, better than lisinopril alone. BP was also lowered from the high levels found at day 7 to normal values in contrast to persistent hypertension of vehicle or MMF rats, an effect that was even more pronounced than that achieved by lisinopril Thus, antiproteinuric therapy completely suppressed the disease in this model only if combined with MMF, which would suggest that immunologic mechanisms can perpetuate parenchymal damage in the circumstance of enhanced protein traffic. Our data do not exclude, however, that the benefit of the addition of MMF to lisinopril could be linked in part to additional anti-inflammatory effects in the glomerulus accounting for full restoration of the integrity of the glomerular filtration compartment and further amelioration of excess protein traffic, or other independent effects of MMF on glomerular cell function in the proteinuric setting.

Intrarenal processing of self epitopes has a role in immune tubulointerstitial injury $(38,39)$. Central in this process is the interaction between the $T$ cell receptor on lymphocyte surface and peptide epitope/MHC class II complexes on dendritic cells, macrophages (17), and renal tubular epithelial cells endowed with antigen-presenting capacity $(40,41)$. Because the disease of remnant kidney is both primarily nonimmune and proteindependent, our results suggest that protein traffic may provide a load of self epitopes possibly including ultrafiltered proteins themselves for local immune processing and consequent lesion progression. Regardless of the underlying mechanism with proteinuria, the ultimate consequences of concomitant antigenindependent and antigen-dependent mechanisms of injury are tubular loss and parenchymal scarring that were inhibited aitogether by combined therapy.

Combined ACE inhibition and MMF immunosuppression is a novel route to therapy and remission of disease for the many conditions of known or undefined etiology associated with enhanced protein traffic that lead to kidney failure. The current treatment is ACEi, which slow, but may not halt. the progression of the disease, and which may not be effective to the same degree in all patients. A kidncy transplant in turn does not lead to lifelong interruption of the process despite available therapies and otherwise noncomplicated course. Patients with a kidney transplant and late graft dysfunction are also candidates for such combined therapy, because their functioning kidney mass is reduced, they are proteinuric, and they need immunosuppression.

\section{Acknowledgments}

We thank Dr. Tullio Bertani for histologic analysis and Patrizia Rossi, Daniela Rottoli, and Gianfranco Marchetti for excellent technical assistance. Dr. Gagliardini is the recipient of a fellowship from the "Collegio dei ragionieri e periti commerciali di Bergamo." 


\section{References}

1. Remuzzi G, Ruggenenti $P$, Benigni A: Understanding the nature of renal disease progression. Kidney Int 51: 2-15, 1997

2. The Gisen Group: Randomised placebo-controlled trial of effect of ramipril on decline in glomerular fituration rate and risk of terminal renal failure in proteinuric, non-diabetic nephropathy. Lancet 349: 1857-1863, 1997

3. Ruggenenti P, Perna A, Mosconi L. Pisoni R, Remuzzi G, on behalf of the GISEN Group: Urinary protein excretion rate is the best independent predictor of ESRF in non-diabetic proteinuric chronic nephropathies. Kidney Int 53; 1209-1216, 1998

4. Wang $\mathrm{Y}$, Chen J, Chen L, Tay Y-C, Rangan GK, Harris DCH: Induction of monocyte chemoattractant protein-1 in proximal tubule cells by urinary protein. $J$ Am Soc Nephrol 8: 1537-1545. 1997

5. Zoja C. Donadelli R. Colleoni S, Figliuzzi M, Bonazzola S, Morigi M, Remuzzi G: Protein overload stimulates RANTES production by proximal tubular cells depending on $N F-\kappa B$ activation. Kidney Int 53: 1608-1615, 1998

6. Zoja C, Morigi M. Figliuzzi M, Bruzzi I, Oldroyd S, Benigni A, Ronco PM, Remuzzi G: Proximul tubular cell synthesis and secretion of endothelin- 1 on challenge with albumin and other proteins. Am J Kidney Dis 26: 934-941, 1995

7. Donadelli R, Zoja C, Benigni A, Bruzzi I, Abbate M, Balducci D, Zanchi $C$. Remuzzi G: ACE inhibition while reducing proteinuria also suppresses NF- $\mathrm{kB}$ activation and reduces renal MCP-1 in rats with remnant kidney [Abstract]. J Am Soc Nephrol 9: 453A, 1998

8. Orisio S, Benigni A, Bruzzi I, Corna D, Perico N, Zoja C, Benatti $\mathrm{L}$, Remuzzi $\mathrm{G}$ : Renal endothelin genc expression is increased in remnant kidney and correlates with disease progression. Kidney Int 43: 354-358, 1993

9. MacCumber MW, Ross CA, Glaser BM, Suyder SH: Endothelin: Visualization of mRNAs by in situ hybridization provides evidence for local action. Proc Natl Acad Sci USA 86: 7285-7289, 1989

10. Tang WW, Qi M, Warren JS, Van GY: Chemokine expression in experimental tubulointerstitial nephritis. $J$ Immunol 159: 870876,1997

11. Zoja C, Liu X-H, Abbate M, Corna D, Schiffrin EL, Remuzzi G. Benigni A: Angiotensin II blockade limits tubular protein overreabsorption and the consequent upregulation of endothelin 1 gene in experimental membranous nephropathy. Exp Nephrol 6: 121-131, 1998

12. Anderson S, Meyer TW, Rennke HG, Brenner BM: Control of glomerular hypertension limits glomerular injury in rats with reduced renal mass. $J$ Clin Invest 76: 612-619, 1985

13. Zoja C, Corna D, Bruzzi I, Foglieni C, Bertani T, Remuzzi G, Benigni A: Passive Heymann nephritis: Evidence that angiotensin-converting enzyme inhibition reduces proteinuria and retards renal structural injury. Exp Nephrol 4: 213-221, 1996

14. Zoja C. Donadelli R, Corna D, Testa D, Facchinetti D, Maffi R, Luzzana E, Colosio V, Bertani T, Remuzzi G: The renoprotecrive properties of angiotensin-converting enzyme inhibitors in a chronic model of membranous nephropathy are solely due to the inhibition of angiotensin II: Evidence based on comparative studies with a receptor antagonist. Am J Kidney Dis 29: 254-264, 1997

15. Ots M, Mackenzie HS, Troy JL, Rennke HG, Brenner BM: Effects of combination therapy with enalapril and losartan on the rate of progression of renal injury in rats with $5 / 6$ renal mass ablation. J Am Soc Nephrol 9: $224-230,1998$
16. Abbate M, Zoja C, Coma D, Capitanio M, Bertani T, Remuzzi G: In progressive nephropathies, overload of tubular cells with filtered proteins translates glomerular permeability dysfunction into cellular signals of interstitial inflammation. $J$ Am Soc Neph. rol 9: 12!3-1224, 1998

17. Banchereau J, Steinman RM: Dendritic cells and the control of immunity, Nature 392: 245-252, 1998

18. Olson JL, Hostetter TH, Rennke HG, Brenner BM, Venkatachalam MA: Altered glomerular permselectivity and progressive sclerosis following extreme ablation of renal mass. Kidney $\mathrm{Imt}$ 22: 112-126, 1982

19. Pfeffer JM, Pfeffer MA, Frohlich ED: Validity of an indirect tail-cuff method for determining systolic anerial pressure in unanesthctized normotensive and spontaneously hypertensive rass. J Lab Clin Med 78: 957-962, 1971

20. Read SM, Northcote DH: Minimization of variation in the response to different proteins of the Coomassie blue $G$ dye-binding assay for protein. Anal Biochem 116: 53-64, 1981

21. Bonses RW, Tausski HA: The colorimetric determination of creatinine of the Jaffé reaction. J Biol Chem 158: 581, 1945

22. Demetris AJ, Murase N, Ye Q. Galvao FHF, Richen C, Saad R, Pham S, Duquesnoy RJ, Zeevi A, Fung JJ, Starzl TE: Analysis of chronic rejection and obliterative arteriopathy. Am J Pathol 150: 563-578, 1997

23. Zoja C, Abbate M, Corna D, Capitanio M, Donadelli R, Bruzzi I, Oldroyd S, Benigni A, Remuzzi G: Pharmacologic control of angiotensin II ameliorates renal disease while reducing renal TGF- $\beta$ in experimental mesangioproliferative glomerulonephritis. Am J Kidney Dis 31: 453-463, 1998

24. Brenner BM, Meyer TW, Hostetter TH: Dietary protein intake and the progressive nature of kidney disease: The role of hemodynamically mediated glomerular injury in the pathogenesis of progressive glomerular sclerosis in aging, renal ablation, and intrinsic renal disease. $N$ Engl $J$ Med 307: 652-659, 1982

25. Remuzzi G, Bertani $T$ : Is glomerulosclerosis a consequence of altered glomerular permeability to macromolecules? Kidney Int 38: $384-394,1990$

26. Remuzzi G, Bertani T: Pathophysiology of progressive nephropathies. $N$ Engl J Med 339: 1448-1456, 1998

27. Eddy AA, McCulloch L, Adams J, Liu E: Interstitial nephritis induced by protein-overload proteinuria. Am J Pathol 135: 719733,1989

28. Remuzzi A, Puntorieri S, Battaglia C, Bertani T, Remuzzi G: Angiotensin converting enzyme inhibition ameliorates glonerular filtration of macromolecules and water and lessens glomerular injury in the rat. $J$ Clin lnvest 85: 541-549. 1990

29. Yoshioka T, Rennke HG, Salant DJ, Deen WM, Ichikawa I: Role of abnormally high transmural pressure in the permselectivity defect of glomenular capillary wall: A study in early passive Heymann nephritis. Circ Res 61: 531-538, 1987

30. Nath KA, Hostetter MK, Hostetter TH: Pathophysiology of chronic tubulo-interstitial disease in rats: Interactions of dietary acid luad, ammonia, and complement compunent C3. I Clin lnvest 76: 667-675, 1985

31. Kees-Folts D, Sadow JL, Schreiner GF: Tubular catabolism of albumin is associated with the release of an inflammatory lipid. Kidney Int 45: 1697-1709. 1994

32. Lee KW, Nadeau K, Troy JL, Tilney NL, Brenner BM, Mackenzie HS: Cytokines and growth factor expression in remnant kidneys of $5 / 6$ nephrectomized Munich-Wistar rats (5/6NPX) [Abstract]. J Am Soc Nephrol 7: 1858, 1996 
33. Eugui EM, Mirkovich A. Allison AC: Lymphocyte-selective antiproliferative and immunosuppressive effects of mycophenolic acid in mice. Scand $J$ Immunol 33: 175-183, 1991

34. Danovitch GM: Mycophenolate mofetil in renal transplantation: Results from the U.S. randomized trials. Kidney Int 48[Suppl 52]: S93-S96, 1995

35. European Mycophenolate Mofetil Cooperative Study Group: Placebo-controlled study of mycophenolate mofeti] combined with cyclosporin and corticosteroids for prevention of acute rejection. Lancet 345: 1321-1325, 1995

36. Azuma H, Binder J. Heemann U, Schmid C, Tulljus SG, Tilney NL: Effects of RS61443 on functional and morphological changes in chronically rejecting rat kidney allografts. Transplantation 59: $460-466,1995$

37. Heemann U, Azuma H, Hamar P, Schmid C, Tilney N, Philipp T: Mycophenolate mofetil inhibits lymphocyte binding and the up- regulation of adhesion molecules in acute rejection of rat kidney allografts. Transplant Immunol 4: 64-67. 1996

38. Hagerty DT, Allen PM: Processing and presentation of self and foreign antigens by the renal proximal tubule. $J$ Immunol 148 : 2324-2330, 1992

39. Haverty TP, Kelly CJ, Hines WH. Amenta PS, Watanbe $M$, Harper RA, Kefalides NA, Neilson EG: Characterization of a renal tubular epithelial cell line which secretes the autologous target antigen of autoimmune experimental interstitial nephritis. J Cell Biol 107: 1359-1368. 1988

40. Haverty TP, Watanabe M, Neilson EG, Kelly CJ: Protective modulation of class II MHC gene expression in tubular epithelium by target antigen-specific antibodies. $J$ Immunol 143: 11331141,1989

41. Rubin-Kelley VE, Jevnikar AM: Antigen presentation by renal tubular epithelial cells. J Am Soc Nephrol 2: 13-26, 1991 



\title{
CHAPTER 6
}

\section{Effect of combining ACE inhibitor and statin in severe experimental nephropathy}

\author{
C. Zoja, D. Corna, D. Rottoli, D. Cattaneo, C. Zanchi, \\ M. Abbate and G. Remuzzi
}

Kidney International 2001, submitted 


\section{ABSTRACT}

Background. Angiotensin converting enzyme (ACE) inhibitor therapy given soon after disease induction uniformly prevents proteinuria in virtually all models of disease progression. This does not necessarily apply to patients with proteinuric nephropathies, who might be referred late in the course of their disease. Here we used a severe rat model of passive Heymann nephritis (PHN), which may mimic advanced phases of human membranous nephropathy, to study the response to $A C E$ inhibitor alone or in combination with a $H M G$ CoA reductase inhibitor (statin) that independently of the cholesterol-lowering effect influences pathways involved in inflammatory and fibrogenic processes. Therapies started when animals had massive proteinuria and renal lesions.

Methods. PHN was accelerated by uninephrectomy 7 days after i.v. injection of rabbit anti-FXIA Ab. Four months later, when massive proteinuria and renal lesions were present, rats were divided into 5 groups and daily given orally: vehicle; lisinopril $40 \mathrm{mg} / \mathrm{L}$; lisinopril $400 \mathrm{mg} / \mathrm{L}$; simvastatin $2 \mathrm{mg} / \mathrm{kg}$ b.i.d; lisinopril $40 \mathrm{mg} / \mathrm{L}$ plus simvastatin. Six normal rats served as controls. Animals were sacrificed at 10 months.

Results. By the end of the study three PHN rats died in the vehicle group, four in the group given lisinopril at $40 \mathrm{mg} / \mathrm{L}$ and two in the group at $400 \mathrm{mg} / \mathrm{L}$, whereas all rats on simvastatin or combined therapy were alive. Blood pressure increased during time in PHN and was normalized by treatment with ACE inhibitor and combined therapy. Lisinopril, even at the high dose, failed to reduce proteinuria. Simvastatin only partially affected proteinuria. Combining lisinopril with simvastatin had instead a remarkable antiproteinuric effect, such that at 10 months urinary proteins were comparable to pre-treatment values and significantly lower than vehicle or lisinopril groups. Hypercholesterolemia of PHN rats was limited by combined therapy, and a positive correlation was found between serum cholesterol and proteinuria. Renal function was only partially ameliorated by simvastatin but significantly improved by combined therapy. Drug combination significantly limited glomerulosclerosis, tubular damage and interstitial inflammation, compared to vehicle or drugs alone. Upregulation of monocyte chemoattractant protein-1 (MCP-1) mRNA in PHN kidneys was not affected by lisinopril, inhibited by $30 \%$ after simvastatin, and almost completely normalized by lisinopril plus simvastatin.

Conclusions. These data suggest that a combined ACE inhibitor and statin approach could represent a therapeutic option for patients with advanced renal disease in whom ACE inhibitors alone fail to lower proteinuria and injury to any substantial extent. 


\section{INTRODUCTION}

Progression to renal parenchymal damage and end-stage renal failure is the final common pathway of chronic proteinuric nephropathies in animals and humans, and appears to be largely independent of the initial type of insult. Pathogenetic factors include altered glomerular permeability to proteins, which are then filtered in excessive quantities to reach the lumen of proximal tubuli. The reabsorption of filtered proteins can contribute to renal interstitial injury by activating proximal tubular cell to behave like an inflammatory cell [1]. Evidence is indeed available that the nuclear transcription factor NF- $\mathrm{kB}$ is activated in proximal tubular cells in conditions of increased protein traffic [2-4], which serves to enhance monocyte chemoattractant protein-1 (MCP-1) gene transcription, whose protein product has potent chemotactic and inflammatory activity in the tubulo-interstitial compartment [5]. Interstitial inflammation and disease progression are both limited by enhanced glomerular permselective function, which effectively limits protein-dependent signaling for interstitial cell infiltration and extracellular matrix deposition [6].

In virtually all experimental models of disease progression, blockade of the renin-angiotensin system by angiotensin converting enzyme (ACE) inhibitors or angiotensin II receptor antagonists, reduces proteinuria and renal injury when the treatment is started in concomitance or soon after disease induction [7-10]. This does not necessarily apply to patients with proteinuric nephropathies who are usually referred much later in the course of their disease. Lipid abnormalities have been implicated in the progression of renal disease [11]. Using the remnant kidney model in rats, Kasiske et al [12] showed that increasing serum cholesterol concentration with cholesterol feeding accelerated the development of progressive renal lesions. Treatment with lipid-lowering agents, namely the 3-hydroxy-3-methylglutaryl coenzyme A (HMG-CoA) reductase inhibitors, or statins, by blocking mevalonate production and thus the rate-limiting step in cholesterol biosynthesis, ameliorated renal function and structure in several rat models of progressive renal diseases, including 5/6 nephrectomy [13], obese Zucker rats [14], streptozotocin-induced diabetes [15] and puromycin-induced nephrotic syndrome $[16,17]$. Suppression of mesangial cell proliferation and macrophage infiltration was achieved in rats with mesangial proliferative nephritis [18]. However, statins' effects exceeded what could be expected on the basis of improvement of dyslipidemia per se, and recently, a direct influence is emerging on important intracellular signaling systems involved in cell proliferation, inflammatory and fibrogenic responses [19]. Thus, statins have been reported to reduce in vitro proliferation of mesangial cells [20] and of tubular epithelial cells [21], to inhibit expression of chemokines such as MCP-1 [22], and 
to modulate mRNAs coding for TGF $\beta$ and matrix components [15,23]. These effects result from the modification of signal transduction proteins by geranylgeranyl- or farnesyl-pyrophosphates generated by the mevalonate pathway [24]. Actually, statins interfere with prenylation of Ras and Rho family small GTPbinding proteins, thereby blocking the activation of mitogen-activated protein kinase (MAPK) signaling pathways and various transcription factors including NF-kB $[19,23]$, which regulates the expression of inflammatory, vasoactive and fibrogenic genes critical to renal disease progression [25].

The present studies have been done in a severe model, accelerated passive Heymann nephritis (PHN) in the rat [26], which may mimic advanced phases of human membranous nephropathy. We sought to investigate the response to $A C E$ inhibitor alone -given in increasing doses- or in combination with simvastatin. Treatment was started when the animals had already massive proteinuria and renal lesions. Outcome parameters included blood pressure control, the magnitude of proteinuria, the degree of renal function and glomerular and tubulo-interstitial changes at 10 months.

\section{MATERIALS AND METHODS}

Experimental design. Male Sprague-Dawley rats (Charles River Italia s.p.a., Calco, Italy) with initial body weights of 300 to $350 \mathrm{~g}$ were used in this study. Animal care and treatment were conducted in accordance with the institutional guidelines that are in compliance with national (Decreto Legislativo n.116, Gazzetta Ufficiale suppl 40, 18 febbraio 1992, Circolare n.8, Gazzetta Ufficiale 14 luglio 1994) and international laws and policies (EEC Council Directive 86/609, OJL358-1, December 1987; Guide for the Care and Use of Laboratory Animals, U.S. National Research Council, 1996). All animals were housed in a room in which the temperature was kept constant on a 12-hour dark/12-hour light cycle and allowed free access to standard diet containing $20 \%$ protein by weight and tap water. Passive Heymann nephritis (PHN) was induced in nonanesthetized rats by a single intravenous injection of $0.4 \mathrm{ml} / 100 \mathrm{~g}$ body wt of rabbit anti-Fx1A antibody. Unilateral nephrectomy at day 7 , when animals are proteinuric, was performed to accelerate the onset of renal histological damage without exacerbating hypertension [26]. Four months later, animals underwent renal biopsy. A small portion of the upper pole of the kidney was surgically removed, and bleeding from the biopsy wound controlled with application of gelform. The renal tissue thus obtained was processed for histological examination as described below. Rats were then divided into 5 groups with equal average glomerular and tubulo-interstitial changes and daily treated up to 10 
months as follows: vehicle (group 1, $\mathrm{n}=8$ ); lisinopril (Merck Sharp \& Dohme Italia, Rome, Italy) $40 \mathrm{mg} / \mathrm{L}$ in the drinking water (group 2, $\mathrm{n}=8$ ); lisinopril $400 \mathrm{mg} / \mathrm{L}$ (group 3, $\mathrm{n}=8$ ); simvastatin (Merck Sharp \& Dohme Italia) $2 \mathrm{mg} / \mathrm{kg}$ b.i.d (group 4, $\mathrm{n}=6$ ); lisinopril $40 \mathrm{mg} / \mathrm{L}$ plus simvastatin $2 \mathrm{mg} / \mathrm{kg}$ b.i.d by gavage (group $5, \mathrm{n}=8$ ). Doses of lisinopril (for group 2) and simvastatin were chosen on the basis of previously published studies $[10,18]$. In group 3 rats, the final dose of $400 \mathrm{mg} / \mathrm{L}$ lisinopril was reached by incremental increases (50 $\mathrm{mg} / \mathrm{L} /$ week) in the dose over the first month, beginning with $200 \mathrm{mg} / \mathrm{L}$. An additional group of normal rats served as control (group 6, $\mathrm{n}=6$ ). Systolic blood pressure, urinary protein excretion and serum creatinine were measured every two months. Serum levels of cholesterol, triglycerides, aspartate transaminase (AST) and alanine aminotransferase (ALT) were assessed at month 4 (before treatment) and at the end of the study. At month 10, rats were anesthetized and kidneys were removed for histology, immunohistochemistry, and Northern blot analysis for MCP-1 mRNA expression. At this time no difference was found in the fixation of rabbit FX1A antibody to glomerular capillary walls by indirect immunofluorescence analysis on kidneys from PHN rats given vehicle $(n=3)$ or treated with lisinopril plus simvastatin $(n=6)$.

Systolic blood pressure (SBP) was recorded by tail plethysmography in conscious rats [27]. Twenty-four hour urine samples were collected using metabolic cages and proteinuria was determined by modified Coomassie blue $\mathrm{G}$ dye-binding assay for proteins with bovine serum albumin as standard [28]. Blood was collected from the tail vein of anesthetized animals. Serum was obtained after whole blood clotting and kept frozen at $-20^{\circ} \mathrm{C}$ until assayed. Creatinine was measured by alkaline picrate method [29]. Serum cholesterol, triglycerides, and transaminase levels were measured using an autoanalyzer (CX5, Beckman Instruments Inc., Fullerton, CA).

Renal histology. The removed kidneys were fixed for 6 h in Dubosq-Brazil, dehydrated in alcohol, and embedded in paraffin. Kidney samples were sectioned at $3 \mu \mathrm{m}$ intervals and the sections were stained with Masson's trichrome, hematoxylin and eosin, and periodic-acid Schiff reagent (PAS stain). Tubular (atrophy, casts, and dilatation) and interstitial changes (fibrosis and inflammation) were graded from 0 to $4+(0$, no changes; $1+$, changes affecting less than $25 \%$ of the sample; $2+$, changes affecting 25 to $50 \%$ of the sample; $3+$, changes affecting 50 to $75 \%$ of the sample; $4+$, changes affecting 75 to $100 \%$ of the sample). At least 100 glomeruli were examined for each animal and the extent of glomerular damage was expressed as the percentage of glomeruli presenting sclerotic lesions. All renal biopsies were analyzed by the same pathologist who was unaware of the nature of the experimental groups. 
Immunohistochemical analysis. Mouse monoclonal antibodies were used for the immunohistochemical detection of the following antigens: ED-1 antigen present in rat monocytes and macrophages (Chemicon, Temecula, CA); CD4+ cell surface glycoprotein, a $55-\mathrm{kD}$ molecule expressed by helper $\mathrm{T}$ cells, thymocytes, and macrophages (W3/25) (Valter Occhiena srl, Torino, Italy); rat CD8+ cell surface glycoprotein expressed by T-suppressor cells (OX8) (PharMingen, Los Angeles, $\mathrm{CA}$ ); and a rat MHC class II antigen monomorphic determinant (OX6) (Valter Occhiena). Detection of ED-1 and CD8 antigens was performed on paraffin sections using an alkaline phosphatase-Fast Red technique as previously described [30]. CD4 and MHC class II antigens were analyzed by indirect immunofluorescence technique. Fragments of renal tissues were frozen in liquid nitrogen and cut at $5 \mu \mathrm{m}$ using a Mikrom $500 \mathrm{O}$ cryostat (Walldorf, Germany). The sections were blocked with $1 \% \mathrm{PBS} / \mathrm{BSA}$, incubated overnight at $4^{\circ} \mathrm{C}$ with the primary antibody (W3/25, $40 \mu \mathrm{g} / \mathrm{ml}$; OX6, $5 \mu \mathrm{g} / \mathrm{ml}$ ), washed with PBS, and then incubated with Cy3-conjugated donkey anti-mouse IgG antibodies $(5 \mu \mathrm{g} / \mathrm{ml}$ in PBS; Jackson ImmunoResearch Laboratories, West Grove, PA) for 1 hour at room temperature. For each marker, positive cells were counted in at least 10 randomly selected high power microscopic fields $(x 400)$ per each animal.

Northern blot analysis. Total RNA was isolated from whole kidney tissue by the guanidium isothiocyanate/cesium chloride procedure, as previously described [31]. Twenty $\mu \mathrm{g}$ of total RNA was then fractionated on $1.6 \%$ agarose gel and blotted onto synthetic membranes (Zeta-probe, Biorad, Richmond, CA). Plasmid containing murine JE/MCP-1 probe was kindly provided by Dr. Charles D. Stiles (Harvard Medical School and Dana-Faber Cancer Institute, Boston, MA). MCP-1 mRNA was detected by using the 577 basepair (bp) of a MCP-1 cDNA. The probes were labeled with $\alpha-32 \mathrm{P}$ dCTP by random-primed method as previously described [4]. Hybridization was performed overnight in 0.5 $\mathrm{mol} / \mathrm{L} \mathrm{Na}_{2} \mathrm{HPO}_{4}, \mathrm{pH} 7.2,7 \%$ SDS. Filters were washed twice for 30 minutes with $40 \mathrm{mmol} / \mathrm{L} \mathrm{Na} \mathrm{HPO}_{4}, \mathrm{pH} \mathrm{7.2,5 \%} \mathrm{SDS} \mathrm{and} \mathrm{two} \mathrm{times} \mathrm{for} 10$ minutes with $40 \mathrm{mmol} / \mathrm{L} \mathrm{Na}_{2} \mathrm{HPO}_{4}, \mathrm{pH} 7.2,1 \% \mathrm{SDS}$ at $65^{\circ} \mathrm{C}$. Membranes were subsequently probed with a glyceraldehyde-3-phosphate dehydrogenase (GAPDH) cDNA, taken as internal standard of equal loading of the samples on the membrane. MCP-1 mRNA optical density was normalized to that of the constituently released GAPDH gene expression.

Statistical analysis. Data are expressed as mean \pm SE. Data were analyzed using the non parametric Kruskal-Wallis test for multiple comparisons. Linear regression analysis was performed between proteinuria and serum cholesterol or triglycerides. The statistical significance level was defined as $\mathrm{P}<0.05$. 


\section{RESULTS}

By the end of the study three PHN rats died in the vehicle group, four in the group given lisinopril $40 \mathrm{mg} / \mathrm{L}$ and two in the group given the high dose of lisinopril $(400 \mathrm{mg} / \mathrm{L})$, while all rats on simvastatin alone or combined therapy were alive.

\section{Food intake and body weight}

Food intake was comparable in all $\mathrm{PHN}$ and control rats for the entire study period. The average food intake at month 10 was as follows: PHN+vehicle, 25 \pm 1 ; PHN+lisinopril $40 \mathrm{mg} / \mathrm{L}, 27 \pm 0.2$; PHN+lisinopril $400 \mathrm{mg} / \mathrm{L}, 26 \pm 0.3$; PHN+simvastatin, 25 \pm ; PHN+lisinopril+simvastatin, 26 \pm ; control, $24 \pm 1$ g/day. All PHN gained weight in a similar manner and at the end of the study body weight values were comparable (vehicle, $613 \pm 32$; lisinopril $40 \mathrm{mg} / \mathrm{L}, 598 \pm 11$; lisinopril 400 $\mathrm{mg} / \mathrm{L}, 588 \pm 26$; simvastatin, $603 \pm 31$ lisinopril + simvastatin, $597 \pm 15 \mathrm{~g}$ ). Body weights of control rats were numerically higher than those of PHN rats, although a statistical significance was not reached $(670 \pm 17 \mathrm{~g})$.

\section{Systolic blood pressure}

As shown in Figure 1, PHN animals were normotensive until 4 months after disease induction (PHN, 135 \pm ; control, $121 \pm 2 \mathrm{mmHg}$ ). Then they exhibited an increase in SBP, which averaged $156 \pm 5 \mathrm{mmHg}$ at the end of the study $(\mathrm{P}<0.01$ vs control, $130 \pm 1 \mathrm{mmHg})$. Treatment with lisinopril alone or combined with simvastatin controlled SBP, with values being significantly $(\mathrm{P}<0.01)$ lower than those of vehicle-rats (lisinopril $40 \mathrm{mg} / \mathrm{L}, 117 \pm 7$; lisinopril 400 $\mathrm{mg} / \mathrm{L}, 119 \pm 6$; lisinopril + simvastatin, $106 \pm 5 \mathrm{mmHg}$ ). In rats given the combined therapy SBP levels were even lower $(\mathrm{P}<0.05)$ than those of control rats. In $\mathrm{PHN}$ rats treated with simvastatin alone SBP values tended to be lower than those of PHN given vehicle (simvastatin, $141 \pm 4 \mathrm{mmHg}$ ).

\section{Urinary protein excretion}

At month 4, before treatments, PHN rats had high levels of urinary protein excretion $(492 \pm 20 \mathrm{mg} /$ day, $\mathrm{n}=38)$. In animals given vehicle proteinuria augmented during time averaging $718 \pm 100 \mathrm{mg} /$ day at month 10 (Figure 2). Lisinopril failed to reduce proteinuria, even at the high dose $(40 \mathrm{mg} / \mathrm{L}, 792 \pm 38 \mathrm{mg} / \mathrm{day}$; $400 \mathrm{mg} / \mathrm{L}, 661 \pm 107 \mathrm{mg} /$ day). In rats given simvastatin alone urinary protein excretion values were numerically lower -although not different-from those of vehicle-group $(601 \pm 84 \mathrm{mg} /$ day). By contrast, combining lisinopril $(40 \mathrm{mg} / \mathrm{L})$ with simvastatin had a remarkable antiproteinuric effect, to the extent that in 4 out of 8 animals urinary proteins at 10 months were less than at 4 months, and 


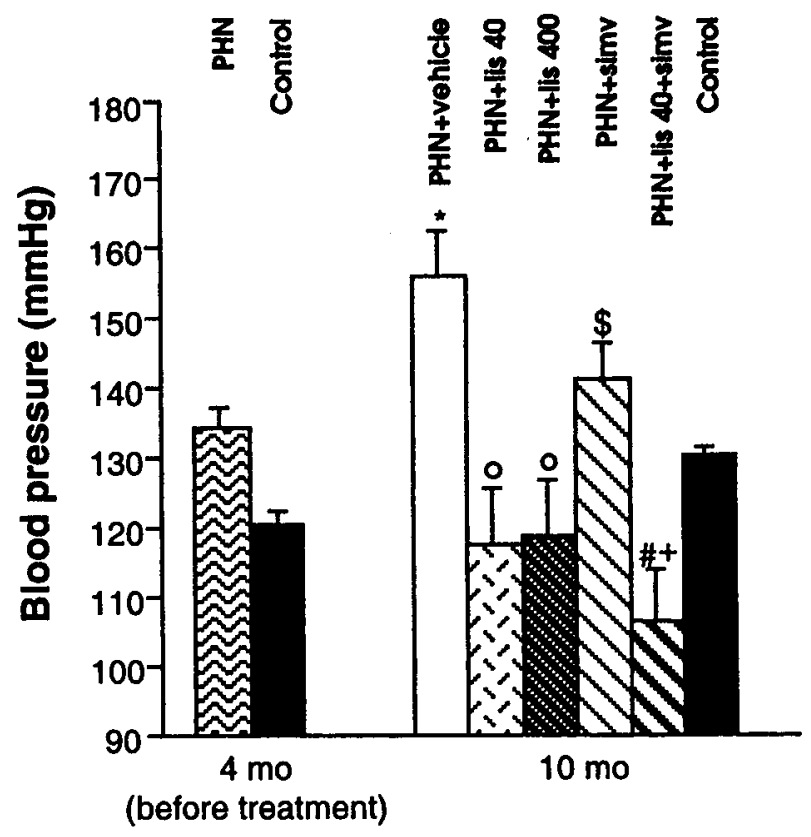

Figure 1: Systolic blood pressure. Data are mean \pm SE. ${ }^{*} \mathrm{P}<0.01$ vs control; ${ }^{\circ} \mathrm{P}<0.01$ vs vehicle; $₫ \mathrm{P}<0.01$ vs lisinopril; $\# \mathrm{P}<0.0$ lvs vehicle and simvastatin; $+\mathrm{P}<0.05$ vs control.

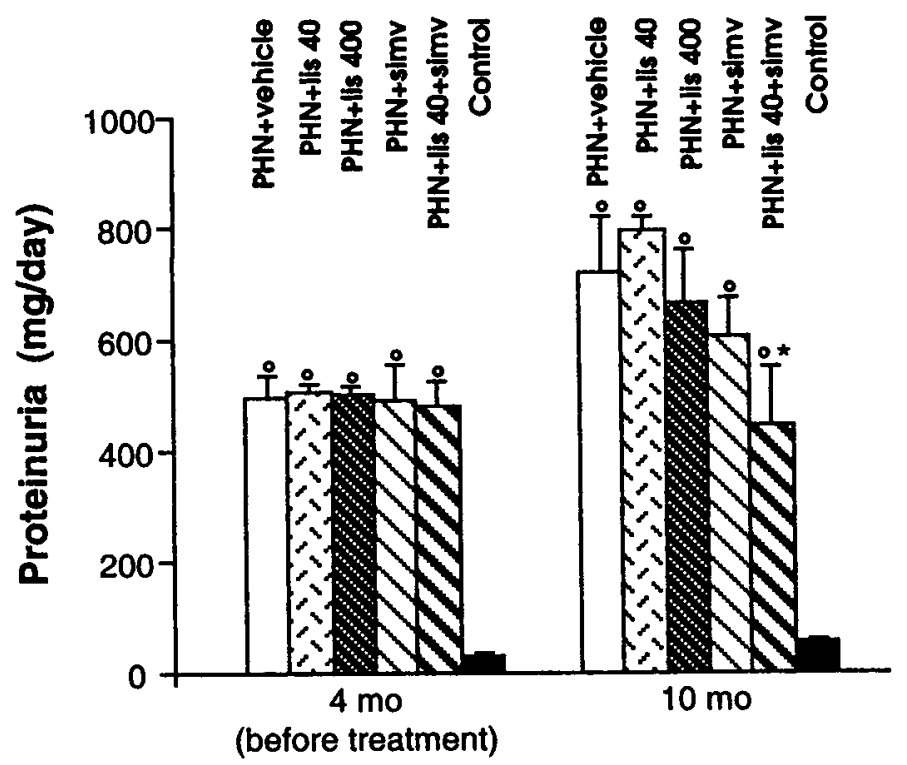

Figure 2: Urinary protein excretion. Data are mean $\pm \mathrm{SE} .{ }^{\circ} \mathrm{P}<0.01$ versus control; ${ }^{*} \mathrm{P}<0.05$ versus vehicle and lisinopril $40 \mathrm{mg} / \mathrm{L}$. 
in 3 rats levels remained stable during time, whereas only one rat did nor respond to therapy. As shown in Figure 2, in this group, at the end of the study, mean value of proteinuria was comparable to that measured before treatment and it was significantly $(P<0.05)$ reduced compared to rats treated with vehicle.

\section{Renal function}

Renal function in PHN rats was already impaired at 4 months and worsened at 10 months, as indicated by serum creatinine levels significantly $(\mathrm{P}<0.01)$ higher than controls (month $4,0.99 \pm 0.02$ vs $0.65 \pm 0.01 \mathrm{mg} / \mathrm{dl}$; month $10,1.54 \pm 0.24$ vs $0.69 \pm 0.02 \mathrm{mg} / \mathrm{dl}$ ) (Figure 3). Lisinopril at both doses did not affect renal function $(40 \mathrm{mg} / \mathrm{L}, 1.55 \pm 0.15 \mathrm{mg} / \mathrm{dl} ; 400 \mathrm{mg} / \mathrm{L}, 1.65 \pm 0.08 \mathrm{mg} / \mathrm{dl}$ ). In PHN rats treated with simvastatin mean value of serum creatinine tended to be lower than in rats given vehicle or lisinopril $(1.32 \pm 0.16 \mathrm{mg} / \mathrm{dl})$, although a statistical significance was not achieved. By contrast, in rats on lisinopril+simvastatin therapy serum creatinine at 10 months $(0.82 \pm 0.04 \mathrm{mg} / \mathrm{dl})$ was fairly comparable to that measured in the same animals before treatment $(0.93 \pm 0.03 \mathrm{mg} / \mathrm{dl})$, and it was significantly $(\mathrm{P}<0.01)$ lower than in other $\mathrm{PHN}$ groups.

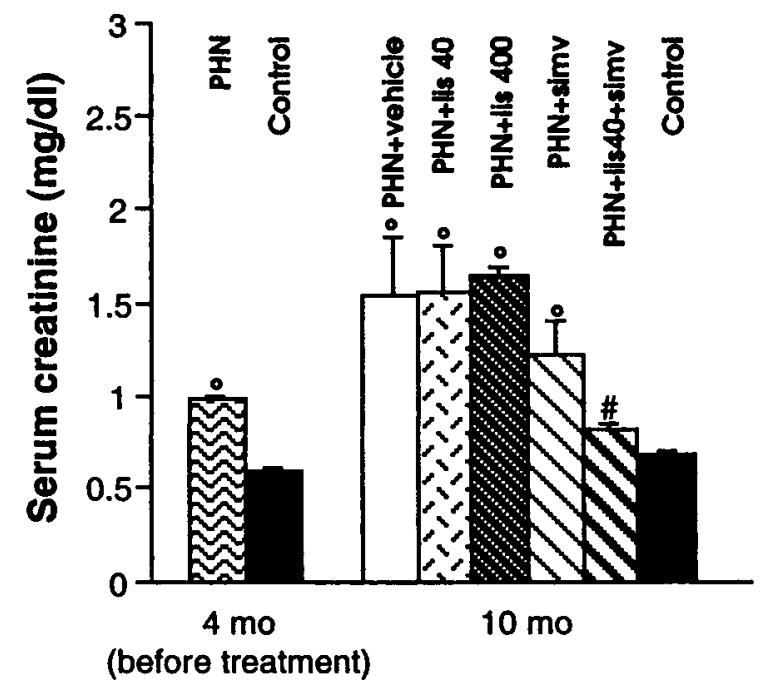

Figure 3: Serum creatinine. Data are mean $\pm \mathrm{SE}$. ${ }^{\circ} \mathrm{P}<0.01$ versus control; $\# \mathrm{P}<0.01$ versus other PHN groups.

\section{Serum cholesterol and triglycerides}

In PHN rats serum cholesterol level increased over time in respect to controls (month $4,132 \pm 11$ vs $58 \pm 4 \mathrm{mg} / \mathrm{dl}$; month $10,151 \pm 22$ vs $70 \pm 6, \mathrm{P}<0.05$ ). As shown in Table 1, treatment with lisinopril did not ameliorate hypercholesterolemia. In the simvastatin group mean value of serum cholesterol tended to 
be lower than in vehicle-rats. This tendency was more evident in animals on lisinopril plus simvastatin therapy. Interestingly, in those 4 out of 8 rats that showed a reduction in proteinuria in respect to pre-treatment levels, serum cholesterol accounted for values within the control range.

Table 1: Serum lipid profile and transaminase levels

\begin{tabular}{lcccc}
\hline Groups & $\begin{array}{c}\text { Serum cholesterol } \\
(m g / d)\end{array}$ & $\begin{array}{c}\text { Serum trig/ycerides } \\
(m g / d)\end{array}$ & $\begin{array}{c}\text { ALT } \\
(I U / L)\end{array}$ & $\begin{array}{c}\text { AST } \\
(I U / L)\end{array}$ \\
\hline PHN+vehicle & $151 \pm 22^{a}$ & $300 \pm 33^{a}$ & $41 \pm 3$ & $86 \pm 10$ \\
PHN+lisinopril (40mg/L) & $246 \pm 15^{a, b}$ & $462 \pm 75^{\text {a,c }}$ & $32 \pm 1$ & $62 \pm 2$ \\
PHN+lisinopril (400mg/L) & $153 \pm 21^{a}$ & $243 \pm 45$ & $34 \pm 5$ & $63 \pm 8$ \\
PHN+simvastatin (4mg/kg) & $137 \pm 22^{a}$ & $342 \pm 56^{\text {a }}$ & $46 \pm 3$ & $73 \pm 4$ \\
PHN+lis40+simvastatin & $126 \pm 16^{a}$ & $235 \pm 45$ & $43 \pm 2$ & $86 \pm 5$ \\
Control & $70 \pm 5$ & $151 \pm 22$ & $58 \pm 6$ & $93 \pm 12$ \\
\hline
\end{tabular}

Values are mean \pm SE. Measurements were performed at month $10 .{ }_{p}^{a}<0.05$ vs control; ${ }^{b} p<0.05$ vs other PHN groups; $c_{p<0.05}$ vs lisinopril $400 \mathrm{mg} / \mathrm{L}$ and combined therapy.

A positive significant correlation $(r=0.85, P<0.001)$ was found between serum cholesterol and urinary protein excretion (Figure 4). Serum triglycerides also correlated with proteinuria, but to a lesser extent $(\mathrm{r}=0.63, \mathrm{P}<0.001)$, probably due to the wide variability of values, as shown in table 1 .

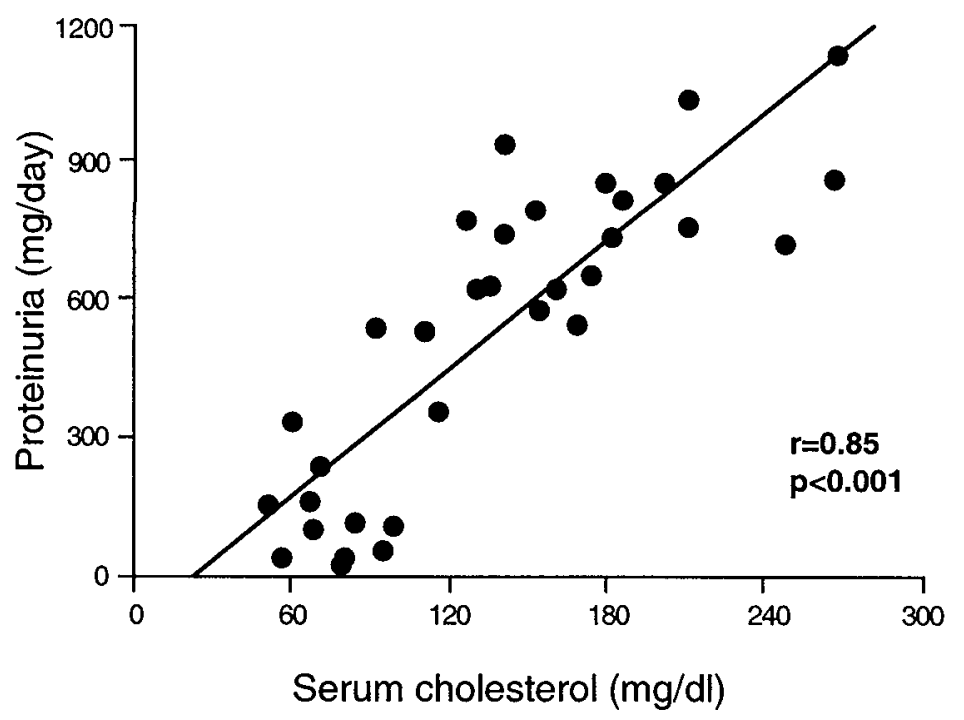

Figure 4: Linear regression analysis of relationship between proteinuria and serum cholesterol performed at 10 months in PHN and control rats. 


\section{Serum transaminase levels}

As depicted in table 1, treatment with lisinopril alone or in combination with simvastatin did not modify serum ALT and AST levels, which were comparable among the all experimental groups.

\section{Renal histology}

The results of the morphological evaluation at biopsy (month 4) and autopsy (month 10) are reported in Table 2. At 4 months, either the percentage of sclerotic glomeruli or the score of tubular damage and interstitial inflammation were significantly increased in PHN rats over controls, and were similar at this time among the five PHN groups by study design. At 10 months, in PHN rats given vehicle, focal and segmental glomerulosclerosis affected on average $68 \%$ of glomeruli, with a 4-fold increase in percentage of sclerotic glomeruli from biopsy to autopsy. Tubulo-interstitial changes consisted of interstitial fibrosis and inflammation associated with tubular atrophy and large eosinophilic casts in the tubular lumen. Scores for tubular damage and interstitial inflammation averaged 2.5 and 3.0, respectively. Both doses of lisinopril had no effect on glomerular and tubulo-interstitial changes. In simvastatin treated rats, glomerulosclerosis and tubular damage were comparable to vehicle-group, whereas interstitial inflammation tended to be less severe. In rats given the combined therapy glomerulosclerosis and tubulo-interstitial changes were dramatically reduced to statistically significant extent compared to the $\mathrm{PHN}$ rats given vehicle or drugs alone. Thus, sclerotic changes in this group were confined on average to $31 \%$ of glomeruli (1.8-fold increase in \% of sclerotic glomeruli from biopsy to autopsy) and the score for tubular damage and interstitial inflammation averaged 1.0 .

Table 2: Renal morphological parameters

\begin{tabular}{lcccccc}
\hline \multirow{2}{*}{ Groups } & \multicolumn{2}{c}{$\begin{array}{c}\text { Glomerulosclerosis } \\
\text { (\%) }\end{array}$} & \multicolumn{2}{c}{$\begin{array}{c}\text { Tubular damage } \\
\text { (score) }\end{array}$} & \multicolumn{2}{c}{$\begin{array}{c}\text { Interstitial Inflammation } \\
\text { (score) }\end{array}$} \\
\cline { 2 - 7 } & $4 \mathrm{mo}$ & $10 \mathrm{mo}$ & $4 \mathrm{mo}$ & $10 \mathrm{mo}$ & $4 \mathrm{mo}$ & $10 \mathrm{mo}$ \\
\hline PHN+vehicle & $18 \pm 4^{\mathrm{a}}$ & $68 \pm 7^{\mathrm{a}}$ & $1.1 \pm 0.1^{\mathrm{a}}$ & $2.5 \pm 0.2^{\mathrm{a}}$ & $1.0 \pm 0.2^{\mathrm{a}}$ & $3.0 \pm 0.2^{\mathrm{a}}$ \\
PHN+lisinopril (40mg/L) & $19 \pm 3^{\mathrm{a}}$ & $63 \pm 10^{\mathrm{a}}$ & $1.1 \pm 0.1^{\mathrm{a}}$ & $2.5 \pm 0.5^{\mathrm{a}}$ & $1.3 \pm 0.2^{\mathrm{a}}$ & $3.0 \pm 0.4^{\mathrm{a}}$ \\
PHN+lisinopril (400mg/L) & $18 \pm 3^{\mathrm{a}}$ & $55 \pm 8^{\mathrm{a}}$ & $1.1 \pm 0.2^{\mathrm{a}}$ & $2.3 \pm 0.5^{\mathrm{a}}$ & $1.2 \pm 0.2^{\mathrm{a}}$ & $2.8 \pm 0.3^{\mathrm{a}}$ \\
PHN+simvastatin (4mg/kg) & $17 \pm 4^{\mathrm{a}}$ & $66 \pm 8^{\mathrm{a}}$ & $1.0 \pm 0.2^{\mathrm{a}}$ & $2.2 \pm 0.2^{\mathrm{a}}$ & $1.2 \pm 0.3^{\mathrm{a}}$ & $2 \pm 0.4^{\mathrm{a}, \mathrm{d}}$ \\
PHN+lis40+simvastatin & $17 \pm 3^{\mathrm{a}}$ & $31 \pm 6^{\mathrm{a}, \mathrm{b}, \mathrm{c}}$ & $1.1 \pm 0.1^{\mathrm{a}}$ & $1.0 \pm 0^{\mathrm{b}, \mathrm{c}}$ & $1.1 \pm 0.1^{\mathrm{a}}$ & $1.1 \pm 0.1$ \\
Control & $0.3 \pm 0.2$ & $2.8 \pm 1.1$ & 0 & $0.5 \pm 0.2$ & 0 & 0 \\
\hline
\end{tabular}

Values are mean $\pm S E .^{a} p<0.01$ vs control; $b<0.01$ vs vehicle and $\operatorname{simvastatin;}^{\mathrm{c}} p<0.05$ vs lisinopril; $\mathrm{d} p<0.01$ vs vehicle and lisinopril 


\section{Inflammatory cell infiltrates in renal interstitium}

Data of the analysis of inflammatory cell infiltrates into the renal interstitium are shown in table 3. Compared with controls, high numbers of ED-1 positive monocytes/macrophages, $C D-4$ positive $T$ cells/macrophages, $C D-8$ positive T-cells, and OX-6 (MHC-II) -positive cells were detected in the interstitium of PHN rats given vehicle, as evaluated at the end of the study. Administration of lisinopril, at both doses, did not substantially affect the numbers of infiltrating cells. A tendency toward a less accumulation of ED-1, CD-8 and MHC-II positive cells was observed in the renal interstitium of rats treated with simvastatin alone in respect to vehicle-rats, although a statistical significance was not reached. By contrast, the degrees of cell infiltrates were significantly limited by the combined therapy, as compared to animals given vehicle or drugs alone.

Table 3: Effect of lisinopril, simvastatin, and their combination on immunostaining of ED1+ macrophages, CD4+ and CD8+ cells, and OX6+ (MHC II) cells

\begin{tabular}{lcccc}
\hline Groups & ED-1+ & CD4+ & CD8+ & OX6+ \\
\hline PHN+vehicle & $54 \pm 3^{\mathrm{b}}$ & $85 \pm 7^{\mathrm{a}}$ & $28 \pm 3^{\mathrm{b}}$ & $99 \pm 5^{\mathrm{a}}$ \\
PHN+lisinopril (40mg/L) & $48 \pm 4^{\mathrm{a}}$ & $100 \pm 6^{\mathrm{a}}$ & $21 \pm 3^{\mathrm{b}}$ & $102 \pm 2^{\mathrm{a}}$ \\
PHN+lisinopril (400mg/L) & $49 \pm 6^{\mathrm{a}}$ & $92 \pm 5^{\mathrm{a}}$ & $24 \pm 4^{\mathrm{b}}$ & $98 \pm 6^{\mathrm{a}}$ \\
PHN+simvastatin (4mg/kg) & $43 \pm 6^{\mathrm{a}}$ & $86 \pm 6^{\mathrm{a}}$ & $17 \pm 6^{\mathrm{a}}$ & $82 \pm 10^{\mathrm{a}}$ \\
PHN+lis 40+simvastatin & $26 \pm 4^{\mathrm{a}, \mathrm{d}, \theta}$ & $62 \pm 5^{\mathrm{a}, \mathrm{l}}$ & $17 \pm 2^{\mathrm{a}, \mathrm{c}}$ & $67 \pm 6^{\mathrm{a}, \mathrm{c}, \mathrm{g}}$ \\
Control & $9 \pm 2$ & $44 \pm 3$ & $2 \pm 1$ & $28 \pm 2$ \\
\hline
\end{tabular}

Values are mean $\pm S E$ (cells/high-power field). ${ }^{a} p<0.05,{ }^{b} p<0.01$ vs control; ${ }^{c} p<0.05,{ }^{d} p<0.01$ vs vehicle; ${ }^{\theta} p<0.05$ vs lisinopril 40 and $400 \mathrm{mg} / \mathrm{L}$ and simvastatin; ${ }^{f} p<0.05$ vs other PHN groups; ${ }^{9} p<0.05$ vs lisinopril 40 and $400 \mathrm{mg} /$.

\section{Renal expression of $M C P-1 \mathrm{mRNA}$}

Consistently with our previous study [4], upregulation of MCP-1 mRNA was observed in the kidney of PHN rats given vehicle in respect to age-matched controls (Figure 5). MCP-1 transcripts were still elevated after lisinopril treatment. In the rats given simvastatin MCP-1 gene upregulation was inhibited by $30 \%$ in respect to vehicle, whereas the MCP-1 signal appeared almost completely normalized after lisinopril plus simvastatin therapy. 


\section{GAPDH}

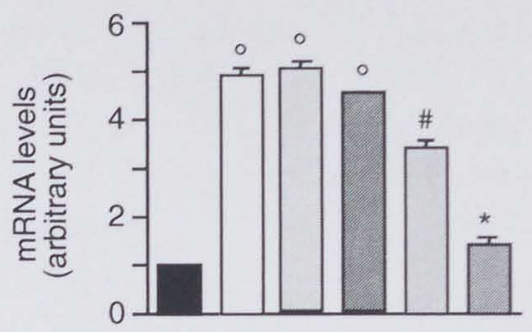

Figure 5: (Left) Renal expression of MCP-1 (Northern blot). (Right) Densitometric analysis. The optical density of the autoradiographic signals was quantitated and calculated as the ratio of MCP-1 to GAPDH mRNA. Results expressed as fold increase over control (represented as 1 ) in arbitrary units. ${ }^{\circ} \mathrm{P}<0.05$ versus control; \# $\mathrm{P}<0.05$ versus control, vehicle and lisinopril $40 \mathrm{mg} / \mathrm{L} ;{ }^{*} \mathrm{P}<0.01$ versus other PHN groups.

\section{DISCUSSION}

ACE inhibitors have a potent antiproteinuric and renoprotective action. In rat models, ACE inhibitors prevented proteinuria and severe structural injury including interstitial lesions, effects which along with blocking of angiotensin II (AII) mediated mechanisms of injury, can be attributed to the drug's ability to limit excess protein traffic across the altered glomerular barrier and its deleterious consequences [6]. This was almost invariably achieved when therapy started early after glomerular insult [7-10]. In proteinuric patients, the greater the effect of ACE inhibitor on proteinuria, the greater the rate of reduction of progressively declining GFR [32]. However, a delayed administration of ACE inhibitor may not be effective enough either in animal models [33-35], or, more importantly, in patients possibly referred late in the course of their disease $[36,37]$.

Here, we took advantage of the severe model of accelerated PHN in the rat [26] and started the treatment when the animals had heavy and persistent proteinuria and already measurable renal lesions, partly resembling advanced phases of human renal disease. We found that lisinopril, at conventional antihypertensive dose $(40 \mathrm{mg} / \mathrm{L})$, actually normalized blood pressure, but nevertheless uniformly failed to ameliorate proteinuria and renal function, and structural lesions. The 
lack of effect of the treatment given late in the course of disease, even in those rats that received up to $400 \mathrm{mg} / \mathrm{L}$ of the $\mathrm{ACE}$ inhibitor, contrasts with findings that earlier treatment ( 7 days after disease induction) had instead effective antiproteinuric properties and lessened tubulo-interstitial inflammation and scarring [4].

The identification of multiple cellular mechanisms of injury has led to the concept of simultaneously interrupting disparate events to slow progression of proteinuric glomerulopathies [26,38-41]. Given the available evidence that statins, independently of their cholesterol-lowering effect, may also influence pathways involved in inflammatory and fibrogenic processes [19], we assessed the effect of combining lisinopril with simvastatin. First we wanted to assess whether statin by itself could affect progression in this model. In fact, simvastatin alone had only quite limited effect on proteinuria and interstitial inflammation, not enough to affect lesion progression to any significant degree. Combined administration of lisinopril and simvastatin had instead a remarkable antiproteinuric and renoprotective effect. It even decreased urinary protein excretion in respect to pre-treatment values in $50 \%$ of rats, and maintained stable levels over time in almost all other animals. As a result, at 10 months the mean value of proteinuria was significantly lower in the combination group than in vehicle and lisinopril groups. Combined therapy afforded remarkable protection against renal function deterioration, and also limited glomerular and tubulo-interstitial damage.

So far, very few studies have evaluated the effect of combination of ACE inhibitor and statin -in comparison with single drug- in progressive renal disease. In the rat model, puromycin-induced nephrotic syndrome, it was shown that treatment with enalapril (from 2 to 8 weeks after puromycin injection), did not affect the course of the disease, whereas lovastatin improved renal function and structure [42]. The combined treatment resulted in further reduction of glomerulosclerosis and urinary protein excretion. It was suggested that lovastatin may promote the improvement in function and histology at least in part by its action of lowering circulating lipids in these rats, or by directly reducing proliferation of mesangial cells, while enalapril could act by lowering protein excretion. In another study, rats with $5 / 6$ nephrectomy were partially protected by enalapril or lovastatin alone (given from 8 to 16 weeks after renal ablation) against progressive glomerulosclerosis, which was almost halted by combination of the two drugs [43]. At variance with the above models, statin alone had a minimal effect against high serum cholesterol of PHN rats. However, a significant correlation was found between proteinuria and serum cholesterol, as evaluated at 10 months in all the experimental groups. Among rats given the combined therapy those with less proteinuria than before treatment also had their 
serum cholesterol kept within the control range. Hence, the amelioration of proteinuria in these animals may have led to improvement of secondary hypercholesterolemia after glomerular injury in PHN. However, hypercholesterolemia and presumably changes in the mevalonate pathway may concur to propagate renal injury [44] and we cannot formally exclude that reduction in high cholesterolemia can be interpreted as an additional factor of renal protection by combined therapy.

The mechanism(s) by which lisinopril plus simvastatin, when initiated late during the course of renal disease of PHN, prevented proteinuria from further worsening can be related to combined drugs' actions on the function of the glomerular filtration barrier to proteins. In a previous study, we found a decrease in the frequency of epithelial filtration slits and increased thickness of the glomerular basement membrane (GBM) in PHN rats. Early treatment with lisinopril preserved the frequency of epithelial slits and prevented the associated loss of the hydraulic permeability of the GBM [45]. Furthermore, blocking AII synthesis or activity preserved in PHN the expression of the slit diaphragm protein, nephrin, in the podocytes [46]. On the other hand, it has been recently reported that statins have the capability to prevent the loss of the anionic sites in the GBM, as documented in 5/6 nephrectomy rats fed a high-cholesterol diet (Suzuki T. personal communication) that may account for the additional antiproteinuric effect when combined with lisinopril. The possibility that the superior protective effect of combined drugs may be ascribed to antiproteinuric action rather than to effects on blood pressure is given further support by evidence that in the same model, the antihypertensive agent lacidipine despite keeping blood pressure within levels comparable to those achieved by the combined therapy in the present study, failed to substantially limit proteinuria and renal damage in contrast to early lisinopril treatment [47].

A major finding in the present study is that the combined therapy, in addition to maintaining proteinuria to stable levels, protected against tubulo-interstitial events that mediate progression of renal damage. Reports have clearly demonstrated that statins additionally interfere with intracellular signaling pathways and transcription of genes involved in inflammation and fibrogenesis [19]. In a rat model of angiotensin II-induced renal injury, treatment with cerivastatin did reduce renal MAP kinase activation and inhibited $A P-1$ and NF-kB activity, thereby limiting leukocyte adhesion and infiltration and ameliorating end-organ damage, independently of changes in serum cholesterol or blood pressure [48]. Here, since evidence is available that statins can reduce expression and production of MCP-1 in vitro [22], we looked at MCP-1, an NF-kB dependent gene, previously found by us to be overexpressed in the kidney of PHN rats in strict association with increase of proteinuria and renal NF-kB activity [4]. 
Upregulation of renal MCP-1 was confirmed in the current study. The high MCP-1 mRNA levels persisted after lisinopril treatment, whereas in rats given simvastatin MCP-1 gene upregulation was inhibited by $30 \%$ in respect to vehicle. Strikingly, in the kidney of PHN rats treated with lisinopril plus simvastatin, MCP-1 transcript levels were almost completely normalized, and interstitial inflammation was significantly reduced. Thus, the beneficial effects of combined therapy against injury can be attributed at least in part, to inhibition of MCP-1-dependent interstitial inflammation by simvastatin, which adds to the protection conferred against both the progressive dysfunction of the glomerular permselective barrier and the consequent proinflammatory phenotype of tubular cells. In this respect, one can also speculate that the molecular mechanisms whereby simvastatin may attenuate tubular cell activation in this setting relate to the ability of statins to inhibit NF-kB $[48,49]$.

In conclusion, the results of this study document that in a severe model of progressive nephropathy resistant to $\mathrm{ACE}$ inhibitor, combining the $\mathrm{ACE}$ inhibitor with a statin arrests proteinuria and protects from renal function and structure impairment. The likely targets of the combined drugs' action are the glomerular permselective dysfunction and, with simvastatin, the secondary proinflammatory activation of tubular epithelial cells, which fosters chronic tubulo-interstitial injury. Such an approach could represent a therapeutic option for patients with advanced renal disease in whom ACE inhibitors alone fail to lower proteinuria and injury to any substantial extent.

\section{References}

1. Remuzzi G: Nephropathic nature of proteinuria. Curr Opin Nephrol Hyperten 8:655663, 1999

2. Zoja C, Donadelli R, Colleoni S, et al: Protein overload stimulates RANTES production by proximal tubular cells depending on NF-kB activation. Kidney Int 53:16081615,1998

3. Wang Y, Rangan GK, Tay Y-C, Harris DCH: Induction of monocyte chemoattractant protein-1 by albumin is mediated by nuclear factor $\mathrm{kB}$ in proximal tubule cells. $\int \mathrm{Am}$ Soc Nephrol 10:1204-1213, 1999

4. Donadelli $\mathrm{R}, \mathrm{Abbate} \mathrm{M}$, Zanchi $\mathrm{C}$, et al: Protein traffic activates NF-kB gene signaling and promotes MCP-1-dependent interstitial inflammation. Am J Kidney Dis 36:1226-1241, 2000

5. Harris DC: Tubulointerstitial renal disease. Curr Opin Nephrol Hyperten 10:303-313, 2001

6. Remuzzi G, Bertani T: Pathophysiology of progressive nephropathies. $N$ Engl J Med 339:1448-1456, 1998 
7. Anderson S, Rennke HG, Brenner BM: Therapeutic advantage of converting enzyme inhibitors in arresting progressive renal disease associated with systemic hypertension in the rat. J Clin Invest 77:1993-2000, 1986

8. Zatz R, Dunn BR, Meyer TW, et al: Prevention of diabetic glomerulopathy by pharmacological amelioration of glomerular capillary hypertension. J Clin Invest 77:19251930,1986

9. Abbate M, Zoja C, Rottoli D, et al: Antiproteinuric therapy while preventing the abnormal protein traffic in proximal tubule abrogates protein- and complement-dependent interstitial inflammation in experimental renal disease. $\int$ Am Soc Nephrol 10:804813,1999

10. Zoja C, Donadelli $\mathrm{R}$, Corna $\mathrm{D}$, et al: The renoprotective properties of angiotensinconverting enzyme inhibitors in a chronic model of membranous nephropathy are solely due to the inhibition of angiotensin II: evidence based on comparative studies with a receptor antagonist. Am J Kidney Dis 29:254-264, 1997

11. Keane WF: Lipids and the kidney. Kidney Int 46:910-920, 1994

12. Kasiske BL, O'Donnell MP, Schmitz Pg, et al: Renal injury of diet-induced hypercholesterolemia in rats. Kidney Int 37:880-891, 1990

13. Kasiske BL, O'Donnell MP, Garvis WJ, Keane WF: Pharmacologic treatment of hyperlipidemia reduces glomerular injury in rat $5 / 6$ nephrectomy model of chronic renal failure. Circ Res 62:367-374, 1988

14. O'Donnell MP, Kasiske BL, Kim Y, et al: Lovastatin retards the progression of established glomerular disease in obese Zucker rats. Am J Kidney Dis 22:83-89, 1993

15. Kim SI, Han DC, Lee HB: Lovastatin inhibits transforming growth factor- $\beta 1$ expression in diabetic rat glomeruli and cultured rat mesangial cells. $J$ Am Soc Nephrol $11: 80-87,2000$

16. Harris KP, Purkerson ML, Yates J, Klahr S: Lovastatin ameliorates the development of glomerulosclerosis and uremia in experimental nephrotic syndrome. Am J Kidney Dis 15:16-23, 1990

17. Park YS, Guijarro C, Kim Y, et al: Lovastatin reduces glomerular macrophage influx and expression of monocyte chemoattractant protein-1 mRNA in nephrotic rats. $\mathrm{AmJ}$ Kidney Dis 31:190-194, 1998

18. Yoshimura A, Inui $\mathrm{K}$, Nemoto $\mathrm{T}$, et al: Simvastatin suppresses glomerular cell proliferation and macrophage infiltration in rats with mesangial proliferative nephritis. $J \mathrm{Am}$ Soc Nephrol 9:2027-2039, 1998

19. Oda H, Keane WF: Recent advances in statins and the kidney. Kidney Int 56 Suppl 71:S2-S5, 1999

20. O'Donnell MP, Kasiske BL, Kim Y, et al: Lovastatin inhibits proliferation of rat mesangial cells. $J$ Clin Invest 91:83-87, 1993

21. Vrtovsnik F, Couette $S$, Priè D, et al: Lovastatin-induced inhibition of renal epithelial tubular cell proliferation involves a p21 ras activated, AP-1-dependent pathway. Kidney Int 52:1016-1027, 1997 
22. Kim SY, Guijarro C, O'Donnell MP, et al: Human mesangial cell production of monocyte chemoattractant protein -1: modulation by lovastatin. Kidney Int 48:363371,1995

23. Kim SI, Kim HJ, Han DC, Lee HB: Effect of lovastatin on small GTP binding proteins and on TGF- $\beta 1$ and fibronectin expression. Kidney Int 58 Suppl 77:S88-S92, 2000

24. Khwaja A, Connolly JO, Hendry BM: Prenylation inhibitors in renal disease. Lancet 355:741-744, 2000

25. Guijarro C, Egido J: Transcription factor-kB (NF-kB) and renal disease. Kidney Int 59:415-424, 2001

26. Benigni A, Corna D, Maffi $\mathrm{R}$, et al: Renoprotective effect of contemporary blocking of angiotensin II and endothelin-1 in rats with membranous nephropathy. Kidney Int 54:353-359, 1998

27. Pfeffer JM, Pfeffer MA, Frohlich ED: Validity of an indirect tail-cuff method for determining systolic arterial pressure in unanesthetized normotensive and spontaneously hypertensive rats. J Lab Clin Med 78:957-962, 1971

28. Read SM, Northcote DH: Minimization of variation in the response to different proteins of the Coomassie blue G dye-binding assay for protein. Anal Biochem 116:5364, 1981

29. Bonsnes RW, Tausski HA: The colorimetric determination of creatinine of the Jaffé reaction. J Biol Chem 158:581, 1945

30. Zoja C, Abbate M, Corna D, et al: Pharmacologic control of Angiotensin II ameliorates renal disease while reducing renal TGF- $\beta$ in experimental mesangioproliferative glomerulonephritis. Am J Kidney Dis 31:453-463, 1998

31. Rambaldi A, Young DC, Griffin JD: Expression of the M-CSF (CSF-1) gene by human monocytes. Blood 69:1409-1413, 1987

32. The Gisen Group: Randomised placebo-controlled trial of effect of ramipril on decline in glomerular filtration rate and risk of terminal renal failure in proteinuric, nondiabetic nephropathy. Lancet 349:1857-1863, 1997

33. Beukers JJB, Van Der Wal A, Hoedemaeker PJ, Weening JJ: Converting enzyme inhibition and progressive glomerulosclerosis in the rat. Kidney Int 32:794-800, 1987

34. Anderson S, Rennke HG, Zatz R: Glomerular adaptations with normal aging and with long-term converting enzyme inhibition in rats. Am J Physiol 267:F35-F43, 1994

35. Scholey JW, Miller PL, Rennke HG, Meyer TW: Effect of converting enzyme inhibition on the course of adriamycin-induced nephropathy. Kidney Int 36:816-822, 1989

36. Fogari $R$, Zoppi A, Corradi $L$, et al: Long-term effects of ramipril and nitrendipine on albuminuria in hypertensive patients with type II diabetes and impaired renal function. J Hum Hypertens 13:47-53, 1999

37. Ruggenenti P, Mosconi L, Sangalli F, et al: Glomerular size-selective dysfunction in NIDDM is not ameliorated by ACE inhibition or by calcium channel blockade. Kidney Int 55:984-994, 1999 
38. Ruggenenti P, Schieppati A, Remuzzi G: Progression, remission, regression of chronic renal diseases. Lancet 357:1601-1608, 2001

39. Remuzzi G, Zoja C, Gagliardini E, et al: Combining an antiproteinuric approach with mycophenolate mofetil fully suppresses progressive nephropathy of experimental animals. J Am Soc Nephrol 10:1542-1549, 1999

40. Hamar P, Peti-Peterdi J, Razga $Z$, et al: Coinhibition of immune and renin-angiotensin systems reduces the pace of glomerulosclerosis in the rat remnant kidney. $J$ Am Soc Nephrol 10:S234-S238, 1999

41. Wang JL, Cheng HF, Shappell S, Harris RC: A selective cyclooxygenase-2 inhibitor decreases proteinuria and retards progressive renal injury in rats. Kidney Int 57:23342342,2000

42. Brouhard BH, Takamori $H$, Satoh $S$, et al: The combination of lovastatin and enalapril in a model of progressive renal disease. Pediatr Nephrol 4:436-440, 1994

43. Lee SK, Jin SY, Han DC, et al: Effects of delayed treatment with enalapril and/or lovastatin on the progression of glomerulosclerosis in $5 / 6$ nephrectomized rats. Nephrol Dial Transplant 8:1338-1343, 1993

44. Wanner $\mathrm{C}$, Quaschning T: Dyslipidemia and renal disease: pathogenesis and clinical consequences. Curr Opin Nephrol Hypertens 10: 195-201, 2001

45. Remuzzi A, Monaci N, Bonassi ME, et al: Angiotensin-converting enzyme inhibition prevents loss of glomerular hydraulic permeability in passive Heymann nephritis. Lab Invest 79:1501-1510, 1999

46. Benigni A, Tomasoni S, Gagliardini E, et al: Blocking angiotensin II synthesis/activity preserves glomerular nephrin in rats with severe nephrosis. J Am Soc Nephrol 12:941948, 2001

47. Benigni A, Gagliardini E, Remuzzi A. et al: ACE inhibition prevents glomerulartubule disconnection and atrophy in passive Heymann nephritis, an effect not observed with a calcium antagonist. Am J Pathol in press

48. Park JK, Muller DN, Mervaala EM, et al: Cerivastatin prevents angiotensin II-induced renal injury independent of blood pressure- and cholesterol-lowering effects. Kidney Int 58:1420-1430, 2000

49. Guijarro C, Kim Y, Schoonover CM, et al: Lovastatin inhibits lipopolysaccharide-induced NF-kB activaction in human mesangial cells. Nephrol Dial Transplant 11:990996, 1996 



\section{CHAPTER 7}

\section{General Discussion}




\section{General Discussion}

Chronic renal diseases with highly enhanced glomerular permeability to proteins are accompanied by tubulointerstitial inflammation and scarring and progression to renal failure [1]. The functional importance of tubulointerstitial events in progressive renal failure is supported by evidence that the severity of tubulointerstitial damage and in particular the macrophage infiltration strongly correlate with the risk of renal progression, even better than the glomerular lesions. Among cellular mechanisms that may trigger tubulointerstitial inflammation, proteins filtered through the glomerular capillary may have intrinsic renal toxicity and serve as an early trigger of interstitial inflammation through the tubular synthesis of excessive amount of vasoactive and inflammatory substances that are released into renal interstitium. Thus, in proximal tubular cells in culture exposed to increasing concentrations of delipidated albumin, IgG or transferrin, the rate of synthesis of endothelin- 1 was enhanced several times in a concentration-dependent fashion [2]. Similarly, albumin and transferrin upregulated MCP-1 gene, an event abrogated by lysine, which inhibits luminal uptake, and by actinomycin $\mathrm{D}$, which limits gene transcription [3].

In chapter 2 of the present thesis it has been described that exposure of proximal tubular cells to high concentrations of albumin resulted in a concentration and time-dependent increase in the production of RANTES, a potent chemoattractant for monocytes/macrophages and $T$ lymphocytes. A similar stimulatory effect on tubular RANTES was observed when cells were challenged with IgG. The large majority of RANTES was secreted into the basolateral compartment of the cells, which would imply that in vivo, RANTES generated in response to protein overload would accumulate into the interstitial space, thus contributing to inflammatory cell recruitment and subsequent fibrosis. The relevance of these findings to the pathophysiology of progressive nephropathies in the context of protein toxicity rests on the demonstration that the RANTES gene was upregulated in the kidneys of mice with crescentic glomerulonephritis that were markedly proteinuric, and that the administration of a RANTES antagonist partially reduced proteinuria and limited glomerular and interstitial accumulation of $\mathrm{T}$ cells and monocytes/macrophages in these animals [4]. Molecular studies have identified NF-kB binding sites within the promoter region of both MCP-1 and RANTES genes [5,6]. NF-kB consists of protein homodimers or heterodimers belonging to the Rel family and exists in an inactive form in the cytoplasm of cell bound to the inhibitory protein IkB [7-9]. Activation of NF$\mathrm{kB}$ by appropriate triggers which include cytokines, activators of protein kinase $\mathrm{C}$, viruses, and oxidants [9] promotes nuclear translocation of the DNA-binding subunits after they are released from IkB. Experiments of electrophoretic 
mobility shift assay performed in nuclear extracts of proximal tubular cells exposed to albumin revealed a dose-dependent increase in NF-kB-DNA binding activity, which was effectively and completely blocked by specific inhibitor interfering with pathways leading to $\mathrm{IkB}$ degradation. That upregulation of inflammatory genes in tubular cells overloaded with proteins is dependent on $\mathrm{NF}-\mathrm{kB}$ activation was proven by our additional data that inhibitors of NF-kB activation fully eliminated the property of albumin of inducing excess RANTES production by cultured tubular cells. The same may apply to other $\mathrm{NF}-\mathrm{kB}$ dependent genes that are rapidly induced in tubular cells by high concentrations of proteins [3]. It is therefore reasonable to assume that overloading proximal tubular cells with various proteins results in a common pathway of activation of NF-kB-dependent genes whose protein products may possibly play a determinant role in recruiting inflammatory cells into renal interstitium.

Relevant to this interpretation might be the data presented in chapter 3 that $\mathrm{NF}-\mathrm{kB}$ is activated in the kidney of rats with progressive proteinuric nephropathies. Thus, in the model of $5 / 6$ nephrectomy, in parallel with proteinuria, kinetic analysis of nuclear extracts by electrophoretic mobility shift assay revealed progressively increased $\mathrm{NF}-\mathrm{kB}$ activity in kidneys studied up to 3 months after surgery. Intense nuclear staining for the $\mathrm{p} 50 \mathrm{NF}-\mathrm{kB}$ subunit was localized to proximal tubular cells. NF-kB activation was paralleled by upregulation of MCP-1 gene expression with time in the remnant kidneys.

Strong MCP-1 mRNA signals were detected in tubular epithelial cells and to a lesser extent in interstitial infiltrating cells as documented by in situ hybridization experiments. MCP-1 mRNA upregulation preceded the accumulation of ED-1 positive monocytes/macrophages and CD8 positive $T$ lymphocytes in the remnant kidney interstitium, suggesting that in this model the initial mononuclear cell recruitment may occur at least in part by MCP-1 dependent mechanisms. In other models of proteinuric nephropathies, renal MCP-1 upregulation has been shown to precede or coincide with the infiltration of mononuclear cells into the renal interstitium $[10,11]$. Moreover, that MCP-1 is functionally important in promoting an interstitial inflammatory response can be derived from the evidence that the administration of a neutralizing anti-MCP-1 antibody to rats with tubulointerstitial nephritis significantly decreased macrophage infiltration [11]. We reasoned that if the interstitial inflammatory reaction were the consequence of the abnormal glomerular filtration and tubular reabsorption of proteins, that also promoted NF-kB activation and chemokine synthesis, limiting the enhanced protein traffic should also limit NF-kB activation, MCP-1 gene upregulation and inflammatory cell recruitment. The best strategy so far in experimental animals and human to lower protein traffic rests on ACE inhibitors which additionally limit renal disease pro- 
gression [1,12-15]. In our study, lisinopril given to rats with remnant kidneys from day 7 after surgery up to days 60 or 90 , while reducing proteinuria, suppressed the enhanced NF-kB binding activity and limited both MCP-1 upregulation and the secondary interstitial inflammatory response, presumably by a common underlying mechanism that can be primarily attributed to the antiproteinuric action of the drug. Similar considerations can be applied also to an immune model, passive Heymann nephritis (PHN). Infact in rats with PHN urinary protein excretion over time was associated with a remarkable increase in renal NF-kB activity, which was normalized by the early administration of lisinopril (from day 7 to month 8 after disease induction). The decrease of NF$\mathrm{kB}$ activation was associated with down-regulation of MCP-1 expression and reduction of mononuclear cell numbers in the renal interstitium.

In a prior study we described that in remnant kidneys after $5 / 6$ renal mass ablation, albumin and Ig accumulated in proximal tubular cells in the early stage, preceding interstitial infiltration of MHC-II positive cells and macrophages [16]. Infiltrates developed at or near tubules containing intracellular IgG or luminal casts. Similar patterns were found in the immune model of PHN, indicating that the interstitial inflammatory reaction develops at the sites of protein overload, regardless of the type of glomerular injury. Among proteins trafficked to the proximal tubule, the third component of complement (C3) can be activated locally and contribute to inflammation at sites of protein reabsorption. As described in chapter 4, we have performed an immunohistochemical analysis of the remnant kidney after 5/6 renal mass reduction to assess whether $\mathrm{C} 3$ can be detected in proximal tubular cells in regions of ultrafiltered protein (Ig) accumulation, and to compare the localization of $\mathrm{C} 3$ and $\mathrm{IgG}$ in proximal tubules with those of monocytes/macrophages and other infiltrating cells bearing MHC-II expression into the interstitium. Results showed that intracellular C3 staining was detectable in proximal tubules as early as 7 days after surgery and was still restricted to proximal tubules at subsequent time points. C3 colocalized with IgG to the same tubules in adjacent sections. Tubular accumulation of ultrafiltered complement has been documented in other models of proteinuric nephropathies. Deposition of C3 in proximal tubules was found in rats with protein overload proteinuria induced by the parenteral administration of heterologous albumin, that develop acute tubulointerstitial nephritis [17]. Similarly, in rats with aminonucleoside nephrosis complement components $\mathrm{C} 3$ and C5b-9 were found on the luminal side of proximal tubular cells as early as 7 days after injection of puromycin aminonucleoside [18]. Deposition of rat C3 and C5b-9 was also observed at the luminal surface and within absorption droplets of proximal tubular cells in the kidneys of proteinuric rats with mesangial proliferative glomerulonephritis [19]. C3 is an essential component of both the classical and 
alternative pathways of complement activation. In vitro evidence is available that proximal tubular cells activate complement via the alternative pathway [20] leading to fixation of the C5b-9 MAC neoantigen on the cell surface [21]. This, in addition, was followed by cytoskeletal alterations, superoxide anion and hydrogen peroxide production, and synthesis of proinflammatory cytokines such as IL- 6 and TNF- $\alpha$ [22]. While the generation of C5b-9 on the apical surface can contribute to functional impairment of proximal tubular cells linked to proteinuria, the $\mathrm{C} 3$ component may have additional and independent proinflammatory actions in proteinuric settings [23]. In this respect, we found evidence of granular C3 staining in the basolateral region of proximal tubular cells, in addition to intracellular sites consistent with subapical and lysosomal compartments. Such reactivity together with the linear peripheral C3 staining may reflect polarized secretion of newly synthesized C3 into the interstitium, a pathway that would reinforce the role of proximal tubular cells as trigger of tubulointerstial injury. Previous in vitro studies did show that proximal tubular epithelial cells synthesize complement components including C3 [24]. Moreover, exposure of human proximal tubular epithelial cells in culture to serum proteins at the apical surface upregulated C3 mRNA expression and enhanced the secretion of the protein predominantly at the basolateral site [26]. In our study protein accumulation in proximal tubular cells was followed by interstitial infiltrates of MHC-II positive cells and ED-1 monocytes/macrophages that were first detectable in the peritubular interstitium of remnant kidney at 14 days and then more evident at 30 days. Treatment with the ACE inhibitor lisinopril prevented or stabilized urinary protein excretion respectively when treatment was started from day 1 or day 7 after surgery. This functional effect was associated with reduction of $\mathrm{C} 3$ and $\operatorname{IgG}$ staining in proximal tubules to comparable level of sham operated control rats, and with the normalization of the number of MHC class II positive cells and monocyte/macrophages in the interstitium at least for those animals given lisinopril from day 1 after surgery. The data suggested that ACE inhibition can be renoprotective by limiting the early abnormal protein traffic in proximal tubule and consequent deleterious effects of excess protein reabsorption, including the accumulation and local activation of complement as well as the induction of endothelin and chemokine genes, whose products may promote interstitial inflammation and fibrosis.

In chapter 5 we addressed the possibility that immune-dependent mechanisms may contribute to severe renal injury in proteinuric rats after extensive renal mass reduction, that causes a primary non-immune insult to the surviving nephrons. By analysing the mononuclear cell populations infiltrating the interstitium of remnant kidney and its relationship with proteinuria, we found that the increase in urinary protein excretion observed from day 7 after surgery, was 
associated with the accumulation of increasingly high numbers of cells expressing $\mathrm{MHC}$ class II antigen into the cortical interstitium. ED-1 positive cells (monocytes/macrophages) were a major component of the interstitial cellular infiltrate, and their numbers increased significantly from day 14 after surgery. Increased numbers of cells with CD4 or CD8 phenotype were found in the remnant kidney interstitium from day 7 , together with the appearance of OX62 positive cells (dendritic cells), which were absent in the kidney of sham-operated control rats. The numbers of all these cell types increased further at subsequent time points, in parallel with increasing levels of proteinuria. These results would point to putative roles for the interaction of lymphocytes, macrophages, and specialized antigen presenting cells in immunologic processes possibly linked to endogenous protein processing and unfolding. Based on these observations suggesting the involvement of lymphocytes in tubulointerstitial injury, we evaluated the effect of combining a specific immunosuppressant, mycophenolate mofetil, with the ACE inhibitor lisinopril, to simultaneously interfere with lymphocyte function and with the protein traffic determinant of interstitial inflammation. Results indicated that the combined therapy dramatically lowered urinary protein excretion to normal levels, preserved glomerular and tubular structural integrity, and suppressed interstitial accumulation of macrophages, T cells, dendritic cells and MHC II overexpression, with such effects being more pronounced than those achieved by ACE inhibitor alone.

The identification of multiple cellular mechanisms of injury has led to the concept of simultaneously interrupting disparate events to slow progression of proteinuric glomerulopathies [1]. Actually, a multidrug approach would possibly represent a therapeutic option for patients in whom ACE inhibitors alone fail to lower proteinuria, particularly those referred late in the course of their disease. In chapter 6 , taking advantage of the severe model of accelerated passive Heymann nephritis (PHN) in the rat, which may mimic advanced phases of human membranous nephropathy, we assessed the effect of combining an ACE inhibitor with a HMG CoA reductase inhibitor (statin) that independently of the cholesterol-lowering effect influences pathways involved in inflammatory and fibrogenic processes [11]. Treatment was started at month 4 after disease induction -when the animals had already massive proteinuria and renal lesionsand lasted until 10 months. Results showed that lisinopril, even if administered to a very high dose, failed to reduce proteinuria. Simvastatin only partially affected proteinuria. Combining lisinopril with simvastatin had instead a remarkable antiproteinuric effect, such that at 10 months urinary proteins were comparable to pre-treatment values and significantly lower than vehicle or lisinopril groups. Drug combination improved renal function and limited glomerulosclerosis, tubular damage and interstitial inflammation, compared to vehicle or 
drugs alone. The mechanism(s) by which the combined therapy prevented proteinuria from further worsening can be related to combined drugs' actions on the function of the glomerular filtration barrier to proteins. In a previous study, we found a decrease in the frequency of epithelial filtration slits and increased thickness of the glomerular basement membrane (GBM) in PHN rats. Early treatment with lisinopril preserved the frequency of epithelial slits and prevented the associated loss of the hydraulic permeability of the GBM [27]. Furthermore, blocking angiotensin II synthesis or activity preserved in PHN the expression of the slit diaphragm protein, nephrin, in the podocytes [28]. On the other hand, it has been recently reported that statins have the capability to prevent the loss of the anionic sites in the GBM, as documented in 5/6 nephrectomy rats fed a high-cholesterol diet that may account for the additional antiproteinuric effect when combined with lisinopril. An important finding of our study is that the combined therapy, in addition to maintaining proteinuria to stable levels, protected against tubulo-interstitial events that mediate progression of renal damage. Reports have clearly demonstrated that statins additionally interfere with intracellular signaling pathways and transcription of genes involved in inflammation and fibrogenesis [26]. Based on the evidence that statins can reduce expression and production of MCP-1 in vitro [29], we looked at MCP-1, an NF-kB dependent gene, which is overexpressed in the kidney of PHN rats in strict association with increase of proteinuria and renal NF-kB activity [see chapter 3]. Upregulation of renal MCP-1 persisted after lisinopril treatment, whereas in rats given simvastatin $M C P-1$ gene upregulation was inhibited by $30 \%$ in respect to vehicle. Strikingly, in the kidney of PHN rats treated with lisinopril plus simvastatin, MCP-1 transcript levels were almost completely normalized, and interstitial inflammation was significantly reduced. Thus, the beneficial effects of combined therapy against injury can be attributed at least in part, to inhibition of MCP-1-dependent interstitial inflammation by simvastatin, which adds to the protection conferred against both the progressive dysfunction of the glomerular permselective barrier and the consequent proinflammatory phenotype of tubular cells. In this respect, one can also speculate that the molecular mechanisms whereby simvastatin may attenuate tubular cell activation in this setting relate to the ability of statins to inhibit NF-kB $[30,31]$. The results of this study document that in a severe model of progressive nephropathy resistant to ACE inhibitor, combining the ACE inhibitor with a statin arrested proteinuria and protected from renal function and structure impairment. The likely targets of the combined drugs' action are the glomerular permselective dysfunction and, with simvastatin, the secondary proinflammatory activation of tubular epithelial cells, which fosters chronic tubulo-interstitial injury. Such an approach could represent a therapeutic op- 
tion for patients with advanced renal disease in whom ACE inhibitors alone fail to lower proteinuria and injury to any substantial extent.

In conclusion, chronic proteinuric nephropathies in animals and humans evolve to terminal renal failure by a process of progressive parenchymal damage, which appears to be independent of the initial insult. An influx of mononuclear cells into the renal interstitium is also a common feature of proteinuric renal diseases evolving to progressive renal scarring and loss of function. Both interstitial inflammation and progression of disease can be limited by drugs that strengthen the glomerular permeability barrier to proteins, thus limiting proteinuria and filtered protein-dependent signaling for mononuclear cell infiltration and extracellular matrix deposition. The underlying cellular mechanisms of injury have been partially clarified and include perturbed proximal tubular cell function and consequent release of vasoactive and inflammatory mediators. These advances should hopefully guide the development of novel multidrug approaches to simultaneously block secondary pathways of progressive renal disease and potentially achieve remission.

\section{References}

1. Remuzzi G, Bertani T: Pathophysiology of progressive nephropathies. $N$ Engl J Med 339:1448-1456, 1998

2. Zoja C, Morigi M, Figliuzzi M, Bruzzi I, Oldroyd S, Benigni A, Ronco PM, Remuzzi G: Proximal tubular cell synthesis and secretion of endothelin- 1 on challenge with albumin and other proteins. Am J Kidney Dis 26:934-94, 1995

3. Wang Y, Chen J, Chen L, Tay Y-C, Rangan GK, Harris DCH: Induction of monocyte chemoattractant protein-1 in proximal tubule cells by urinary protein. $J \mathrm{Am}$ Soc Nephrol 8:1537-1545, 1997

4. Lloyd CM, Minto AW, Dorf ME, Proudfoot A, Wells TNC, Salant DJ, GutierrezRamos J-C: RANTES and monocyte chemoattractant protein-1 (MCP-1) play an important role in the inflammatory phase of crescentic nephritis, but only MCP-1 is involved in crescent formation and interstitial fibrosis. J Exp Med 185:1371-1380, 1997

5. Ueda A, Okuda K, Ohno S, Shirai A, Igarashi T, Matsunaga K, Fukushima J, Sawamoto $S$, Ishigatsubo Y, Okubo T: NF-kB and Sp1 regulate transcription of the human monocyte chemoattractant protein-1 gene. J Immunol 153:2052-2063, 1994

6. Nelson PJ, Kim HT, Manning WC, Goralski TJ, Krensky AM: Genomic organization and transcriptional regulation of the RANTES chemokine gene. I Immunol 151:2601-2612, 1993

7. Baeuerle PA, Henkel T: Function and activation of NF-kB in the immune system. Annu Rev Immunol 12:141-179, 1994 
8. Baldwin AS: The NF-kB and IkB proteins: new discoveries and insights. Annu Rev Immunol 14:649-681, 1996

9. Barnes PJ, Karin M: Nuclear factor-kB - A pivotal transcription factor in chronic inflammatory diseases. $N$ Engl J Med 356:1066-1071, 1997

10. Eddy AA, Giachelli CM: Renal expression of genes that promote interstitial inflammation and fibrosis in rats with protein-overload proteinuria. Kidney Int 47:15461557,1995

11. Tang WW, Qi M, Warren JS, Van GY: Chemokine expression in experimental tubulointerstitial nephritis. J Immunol 159:870-876, 1997

12. Anderson S, Rennke HG, Brenner BM: Therapeutic advantage of converting enzyme inhibitors in arresting progressive renal disease associated with systemic hypertension in the rat. J Clin Invest 77:1993-2000, 1986

13. Ots M, Mackenzie HS, Troy JL, Rennke HG, Brenner BM: Effects of combination therapy with Enalapril and Losartan on the rate of progression of renal injury in rats with 5/6 renal mass ablation. J Am Soc Nephrol 9:224-230, 1998

14. Zoja C, Donadelli R, Corna D, Testa D, Facchinetti D, Maffi R, Luzzana E, Colosio $\mathrm{V}$, Bertani T, Remuzzi G: The renoprotective properties of angiotensin-converting enzyme inhibitors in a chronic model of membranous nephropathy are solely due to the inhibition of angiotensin II: evidence based on comparative studies with a receptor antagonist. Am J Kidney Dis 29:254-264, 1997

15. The Gisen Group: Randomised placebo-controlled trial of effect of ramipril on decline in glomerular filtration rate and risk of terminal renal failure in proteinuric, nondiabetic nephropathy. Lancet 349:1857-1863, 1997

16. Abbate M, Zoja C, Corna D, Capitanio M, Bertani T, Remuzzi G: In progressive nephropathies, overload of tubular cells with filtered proteins translates glomerular permeability dysfunction into cellular signals of interstitial inflammation. $J$ Am Soc Nephrol 9:1213-1224,1998

17. Eddy AA: Interstitial nephritis induced by protein-overload proteinuria. Am J Pathol 135:719-733, 1989

18. Nomura A, Morita Y, Maruyama S, Hotta N, Nadai M, Wang L, Hasegawa T, Matsuo S: Role of complement in acute tubulointerstitial injury of rats with aminonucleoside nephrosis. Am J Pathol 151:539-547,1997

19. Morita X, Nomura A, Yuzawa Y, Nishikawa K, Hotta N, Smimizu F, Matsuo S: The role of complement in the pathogenesis of tubulointerstitial lesions in rat mesangial proliferative glomerulonephritis. J Am Soc Nephrol 8:1363-1372,1997

20. Camussi G, Rotunno M, Segoloni G, Brentjens JR, Andres GA: In vitro alternative pathway activation of complement by the brush border of proximal tubules of normal rat kidney. J Immunol 128:1659-1663,1982

21. Biancone L, David S, Della Pietra V, Montrucchio G, Cambi V, Camussi G: Alternative pathway activation of complement by cultured human proximal tubular epithelial cells. Kidney Int 45:451-460,1994 
22. David S, Biancone L, Caserta C, Bussolati B, Cambi V, Camussi G: Alternative pathway complement activation induces proinflammatory activity in human proximal tubular epithelial cells. Nephrol Dial Transplant 12:51-56,1997

23. Nath KA, Hostetter MK, Hostetter TH: Pathophysiology of chronic tubulo-interstitial disease in rats. Interactions of dietary acid load, ammonia, and complement component C3. J Clin Invest 76:667-675,1985

24. Brooimans RA, Stegmann APA, van Dorp WT, van der Ark AAJ, van der Woude FJ, van Es LA, Daha MR: Interleukin 2 mediates stimulation of complement $\mathrm{C} 3$ biosynthesis in human proximal tubular epithelial cells. J Clin Invest 88:379-384,1991

25. Tang S, Sheerin NS, Zhou W, Brown Z, Sacks SH: Apical proteins stimulate complement synthesis by cultured human proximal tubular epithelial cells. J Am Soc Nephrol 10:69-76, 1999

26. Oda H, Keane WF: Recent advances in statins and the kidney. Kidney Int 56:Suppl 71:S2-S5, 1999

27. Remuzzi A, Monaci N, Bonassi ME, et al: Angiotensin-converting enzyme inhibition prevents loss of glomerular hydraulic permeability in passive Heymann nephritis. Lab Invest 79:1501-1510, 1999

28. Benigni A, Tomasoni S, Gagliardini E, et al: Blocking angiotensin II synthesis/activity preserves glomerular nephrin in rats with severe nephrosis. J Am Soc Nephrol 12:941948,2001

29. Kim SY, Guijarro C, O'Donnell MP, et al: Human mesangial cell production of monocyte chemoattractant protein -1: modulation by lovastatin. Kidney Int 48:363371, 1995

30. Park JK, Muller DN, Mervaala EM, et al: Cerivastatin prevents angiotensin II-induced renal injury independent of blood pressure- and cholesterol-lowering effects. Kidney Int 58:1420-1430, 2000

31. Guijarro C, Kim Y, Schoonover CM, et al: Lovastatin inhibits lipopolysaccharide-induced NF-kB activaction in human mesangial cells. Nephrol Dial Transplant 11:990996, 1996 
CHAPTER 8

\section{Summary}




\section{Summary}

Progression to end-stage renal failure is the final common pathway of many forms of glomerular disease, independent of the type of initial insult. Progressive glomerulopathies have in common persistently high levels of urinary protein excretion and tubulointerstitial lesions. Among the cellular mechanisms that may determine progression regardless of etiology, the traffic of excess proteins filtered from glomerulus in renal tubule may have functional importance by initiating interstitial inflammation through the tubular synthesis of excessive amount of vasoactive and inflammatory substances that are released into renal interstitium (reviewed in chapter 1).

In this thesis further investigations were performed to address the renal toxicity of enhanced glomerular protein traffic, with the aims of clarifying the relevant tubular-dependent pathways of interstitial inflammation ultimately responsible for renal scarring and loss of function, and of identifying antiproteinuric and renoprotective therapies to slow or even halt the disease progression to endstage renal failure.

In chapter 2 we investigated in vitro the effect of protein overload on proximal tubular cell production of RANTES, a nuclear factor-kB (NF-kB)-dependent chemokine with potent chemotactic activity for monocytes/macrophages and $T$ lymphocytes. Incubation of confluent pig proximal tubular cells with increasing concentrations of bovine serum albumin time- and dose- dependently increased RANTES release that was predominantly basolateral. If this occurred in vivo, it means that RANTES generated in response to protein overload accumulates into the interstitial space and contributes to interstitial inflammation by promoting mononuclear cell recruitment. The stimulatory effect on tubular RANTES was not specific to albumin but was shared by $\operatorname{IgG}$. We then explored the role of NF-kB on albumin-induced RANTES. The NF-kB inhibitors pyrrolidine dithiocarbamate (PDTC) and sodium salicylate significantly reduced albumininduced RANTES production. Electrophoretic mobility shift assay of nuclear extracts of tubular cells exposed to albumin revealed an intense NF- $\mathrm{kB}$ activation, in a dose-dependent fashion, which was inhibited by PDTC. These data identified a novel mechanism, which may not be confined to RANTES, by which the process of reabsorption of filtered proteins activates proximal tubular epithelium, and thus explains in biochemical terms the renal toxicity of protein trafficking.

Mononuclear cells accumulate into the renal interstitium and contribute to renal injury in proteinuric nephropathies. Angiotensin converting enzyme (ACE) 
inhibitors reduce protein trafficking and also lessen renal structural and functional damage. Many proinflammatory genes including MCP-1, a chemoattractant for monocytes and $T$ lymphocytes, are transcriptionally regulated by NF$\mathrm{kB}$. In chapter 3 we aimed to study renal NF-kB activation and gene expression of MCP-1 over time in two models of progressive proteinuric nephropathies ( $5 / 6$ nephrectomy and passive Heymann nephritis, PHN). Moreover, we evaluated the effect of reducing protein traffic -by means of an antiproteinuric therapy with ACE inhibitor- on NF-kB activation, MCP- 1 expression, and the extent of accumulation of mononuclear cells into the renal interstitium. In both models increased urinary protein excretion over time was associated with a remarkable increase in renal NF-kB activity, which was almost completely suppressed by reducing proteinuria with lisinopril. NF-kB activation was paralleled by upregulation of MCP-1 mRNA that preceded interstitial accumulation of ED-1 positive monocyte/macrophages and $\mathrm{CD} 8$ positive $T$ cells. Lisinopril inhibited MCP-1 upregulation and limited interstitial inflammation. These data suggest that enhanced protein traffic is crucial for NF-kB activation and downstream pathways of interstitial inflammation and its limitation by ACE inhibitor also limit MCP-1 gene upregulation and inflammatory cell recruitment into renal interstitium.

In proteinuric glomerulopathies, the excess traffic of proteins into the renal tubule is a candidate trigger of interstitial inflammatory and immune events leading to progressive injury, and a key target for the renoprotective action of antiproteinuric drugs. Among proteins trafficked to the proximal tubule, the third component of complement (C3) can be activated locally and contribute to inflammation at sites of protein reabsorption. In chapter 4 we performed experiments in rats with renal mass reduction (RMR, 5/6 nephrectomy) with the following aims: 1) to study IgG and complement deposition in proximal tubules, and interstitial macrophage infiltration and MHC-class II expression at intervals after surgery by double immunofluorescence analysis; 2) to assess whether lisinopril, given from either day 1 or day 7 limited IgG and C3 accumulation and interstitial inflammation. At 7 day intracellular staining for both $\mathrm{IgG}$ and $\mathrm{C} 3$ was detectable in proximal tubules in focal areas; $\mathrm{C} 3$ was restricted to IgG-positive tubular cells, and there were no interstitial ED-1 macrophage and MHC-II-positive cellular infiltrates. In 14 day and 30 day remnant kidneys, proximal tubular IgG and C3 staining was associated with the appearance of interstitial infiltrates which preferentially localized to areas of tubules positive for both proteins. RMR rats given the ACE inhibitor had no or limited increases in levels of urinary protein excretion, tubular IgG and C3 reactivity, and interstitial cellular infiltrates in kidneys at 30 days, even when ACE inhibitor was 
started from day 7 after surgery. These findings document that 1) in RMR, IgG and $\mathrm{C} 3$ accumulation in proximal tubular cells is followed by leukocyte infiltration and MHC-II overexpression in the adjacent interstitium; 2) ACE inhibitor while preventing proteinuria limits both tubular accumulation of IgG and C3 and interstitial inflammation. The data suggest that ACE inhibition can be renoprotective by limiting the early abnormal protein traffic in proximal tubule and the consequent deleterious effects of excess protein reabsorption, including the accumulation and local activation of complement as well as the induction of chemokines and endothelin coding genes known to promote interstitial inflammation and fibrosis.

In chapter 5 we tested the hypothesis that excess intrarenal protein traffic may cause lymphocyte-dependent interstitial injury that, while not fully controlled by antiproteinuric therapy, can be further inhibited by concomitant immunosuppression. A primarily non immune model, 5/6 nephrectomy in the rat, was used to reproduce progressive renal disease due to a critical loss of nephron mass. We characterized the mononuclear cell population infiltrating the interstitium and compared the effects of combining ACE inhibitor and an anti-lymphocyte agent versus either drug alone against disease. Results showed that the increase in urinary protein excretion observed from day 7 after surgery, was associated with the accumulation of increasingly high numbers of cells expressing MHC-class II antigen into the cortical interstitium. ED-1 positive cells (monocytes/macrophages) were a major component of the interstitial cellular infiltrate, and their numbers increased significantly from day 14 after surgery. Increased numbers of cells with CD4 or CD8 phenotype were found in the remnant kidney interstitium from day 7, together with the appearance of OX62 positive cells (dendritic cells), which were absent in the kidney of sham-operated control rats. Further increase of all these cell types with time paralleled increasing levels of proteinuria. Treatment with the ACE inhibitor lisinopril limited proteinuria, interstitial inflammation, MHC-class II antigen expression, and severe lesions. Combined treatment with ACE inhibitor and a specific anti-lymphocyte agent, mycophenolate mofetil, dramatically attenuated macrophage and $\mathrm{T}$ cell infiltration, MHC-class II overexpression, dendritic cells, and all manifestations of the disease. Evidence of lymphocyte-mediated renal injury in the setting of excess protein traffic provides the basis for combining ACE inhibition and immunosuppression to halt progression of proteinuric kidney disease and minimize the need for dialysis or transplantation.

ACE inhibitor therapy given soon after disease induction prevents proteinuria in virtually all models of disease progression. This does not necessarily apply to 
patients with proteinuric nephropathies, who might be referred late in the course of their disease. In chapter 6 we used a severe rat model of passive Heymann nephritis (PHN), which may mimic advanced phases of human membranous nephropathy, to study the response to ACE inhibitor alone or in combination with a HMG CoA reductase inhibitor (statin) that independently of the cholesterol-lowering effect influences pathways involved in inflammatory and fibrogenic processes. Four months after disease induction, when animals developed massive proteinuria and renal lesions, they were divided into 5 groups and daily given orally for 6 months: vehicle; lisinopril $40 \mathrm{mg} / \mathrm{L}$; lisinopril 400 $\mathrm{mg} / \mathrm{L}$; simvastatin $2 \mathrm{mg} / \mathrm{kg}$ b.i.d; lisinopril $40 \mathrm{mg} / \mathrm{L}$ plus simvastatin. Six normal rats served as controls. Blood pressure increased during time in PHN and was normalized by treatment with ACE inhibitor and combined therapy. Lisinopril, even at the high dose, failed to reduce proteinuria. Simvastatin only partially affected proteinuria. Combining lisinopril with simvastatin had instead a remarkable antiproteinuric effect, such that at 10 months urinary proteins were comparable to pre-treatment values and significantly lower than vehicle or lisinopril groups. Renal function was only partially ameliorated by simvastatin but significantly improved by combined therapy. Drug combination significantly limited glomerulosclerosis, tubular damage and interstitial inflammation, compared to vehicle or drugs alone. Upregulation of MCP-1 mRNA in PHN kidneys was not affected by lisinopril, inhibited by $30 \%$ after simvastatin, and almost completely normalized by lisinopril plus simvastatin. These data suggest that a combined ACE inhibitor and statin approach could represent a therapeutic option for patients with advanced renal disease in whom ACE inhibitors alone fail to lower proteinuria and injury to any substantial extent. 


\section{Curriculum vitae}

Carlamaria Zoja was born in Bergamo, Italy, on August 9th 1955. She took the upper-school leaving certificate at 'Liceo Classico Paolo Sarpi' of Bergamo on 1974.

She graduated in Biological Sciences at Università degli Studi di Milano on July 13rd 1979. From September 1979 to April 1981 she had a fellowship from the "Associazione Bergamasca per lo Studio delle Malattie Renali", at the Laboratory of Division of Nephrology and Dialysis, Ospedali Riuniti di Bergamo, directed by Prof. Giuliano Mecca, in the pioneering research group of Prof. Giuseppe Remuzzi. At that time she was involved in studies on vascular prostaglandin biology in pregnancy and in Hemolytic Uremic Syndrome. She had the opportunity to spend the next two years as post doctoral fellow at the Center for Thrombosis and Vascular Research, Katholieke Universiteit, Leuven, Belgium, directed by Prof. Marc Verstraete, working in the group of Prof. Jos Vermylen and his assistant Dr. Hans Deckmyn. Back from Leuven on November 1983, she started working at the Mario Negri Institute for Pharmacological Research of Bergamo in the Laboratory of Kidney Disease coordinated by Prof. Giuseppe Remuzzi, obtaining a position as Scientist on May 1985. On January 1989 she became head of the Unit of Experimental Modeling for Human Renal Diseases and since January 1995 she is head of the Laboratory of Experimental Models of Kidney Disease. In these years she has contributed to studies on experimental models of kidney diseases to identify vasoactive and inflammatory mediators of renal disease progression and to find out novel antiproteinuric and renoprotective drugs. Another main research topic has related to the role of verotoxin in the pathogenesis of endothelial dysfunction and microvascular thrombosis in Hemolytic Uremic Syndrome.

She has authored and co-authored 102 scientific articles, reviews and monographs and 108 abstracts published in international journals. 


\section{Acknowledgments}

I wish to express my deep gratitude to Prof. Giuseppe Remuzzi who always supported and encouraged me and my work during these years.

I thank my colleagues and friends Daniela Corna, Marina Morigi, Mauro Abbate, Ariela Benigni, Antonella Piccinelli and Roberta Donadelli for their continued and helpful collaboration.

I am indebted to Prof. Karel Leunissen for the opportunity he gave me to discuss my $\mathrm{PhD}$ thesis in the prestigious Universiteit Maastricht. 